Prepared in cooperation with the Oklahoma Department of Transportation

\title{
StreamStats in Oklahoma-Drainage-Basin Characteristics and Peak-Flow Frequency Statistics for Ungaged Streams
}

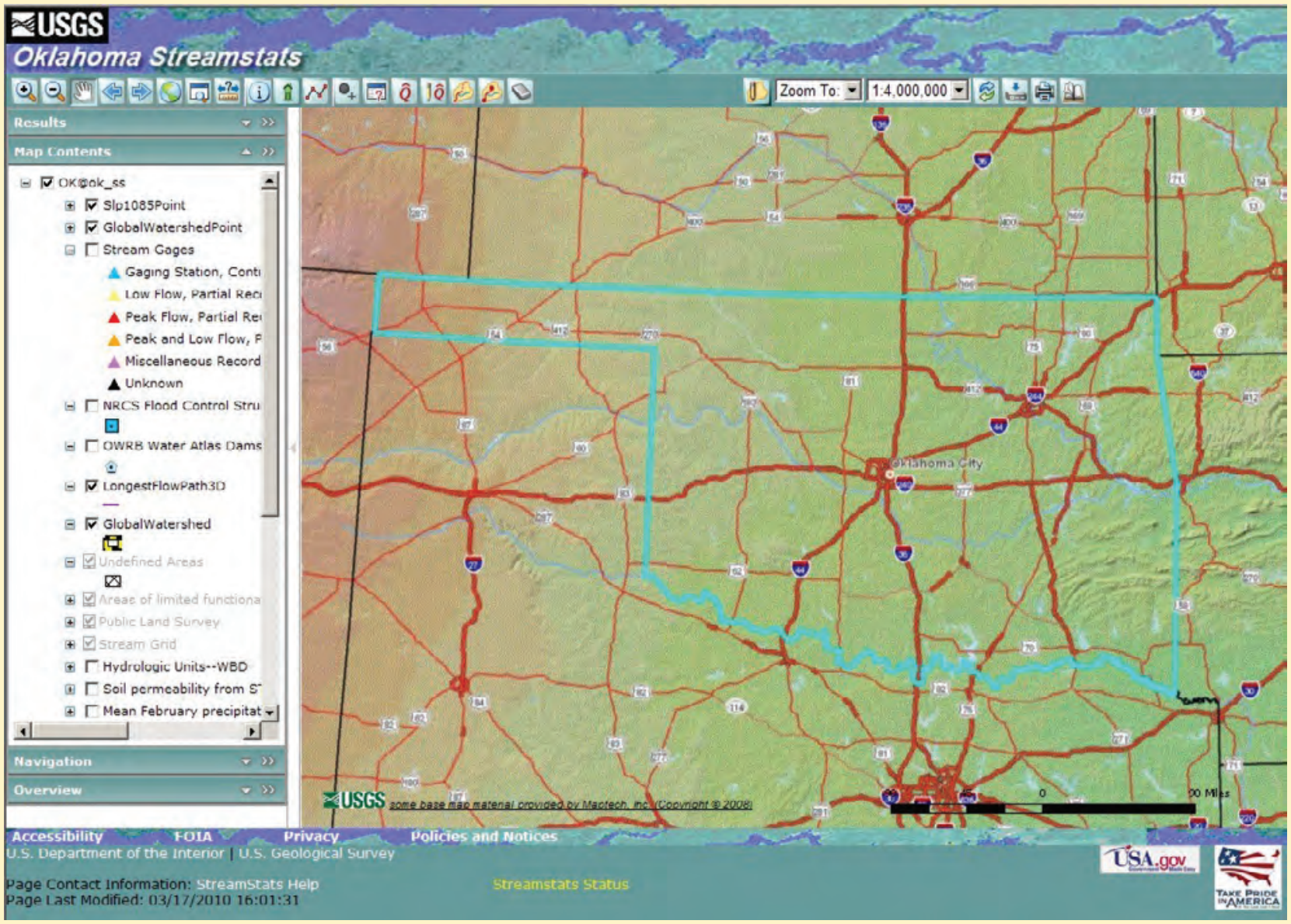

Scientific Investigations Report 2009-5255 
On the cover: User interface for the Oklahoma StreamStats web applicaton. 
Publishing support provided by:

Lafayette Publishing Service Center

For more information concerning this publication, contact Director, USGS Oklahoma Water Science Center

202 NW 66th St., BIdg. 7

Oklahoma City, OK 73116

(405) $810-4400$

Or visit the Oklahoma Water Science Center Web site at: http://ok.water.usgs.gov 


\section{StreamStats in Oklahoma-Drainage- Basin Characteristics and Peak-Flow Frequency Statistics for Ungaged Streams}

By S. Jerrod Smith and Rachel A. Esralew

Prepared in cooperation with the Oklahoma Department of Transportation

Scientific Investigations Report 2009-5255 


\section{U.S. Department of the Interior \\ KEN SALAZAR, Secretary \\ U.S. Geological Survey \\ Marcia K. McNutt, Director}

U.S. Geological Survey, Reston, Virginia: 2010

This and other USGS information products are available at http://store.usgs.gov/
U.S. Geological Survey
Box 25286 , Denver Federal Center
Denver, CO 80225
To learn about the USGS and its information products visit http://www.usgs.gov/
1-888-ASK-USGS

Any use of trade, product, or firm names is for descriptive purposes only and does not imply endorsement by the U.S. Government.

Although this report is in the public domain, permission must be secured from the individual copyright owners to reproduce any copyrighted materials contained within this report.

Suggested citation:

Smith, S.J., and Esralew, R.A., 2010, StreamStats in Oklahoma-Drainage-Basin Characteristics and Peak-Flow Frequency Statistics for Ungaged Streams: U.S. Geological Survey Scientific Investigations Report 2009-5255, 59 p. 


\section{Contents}

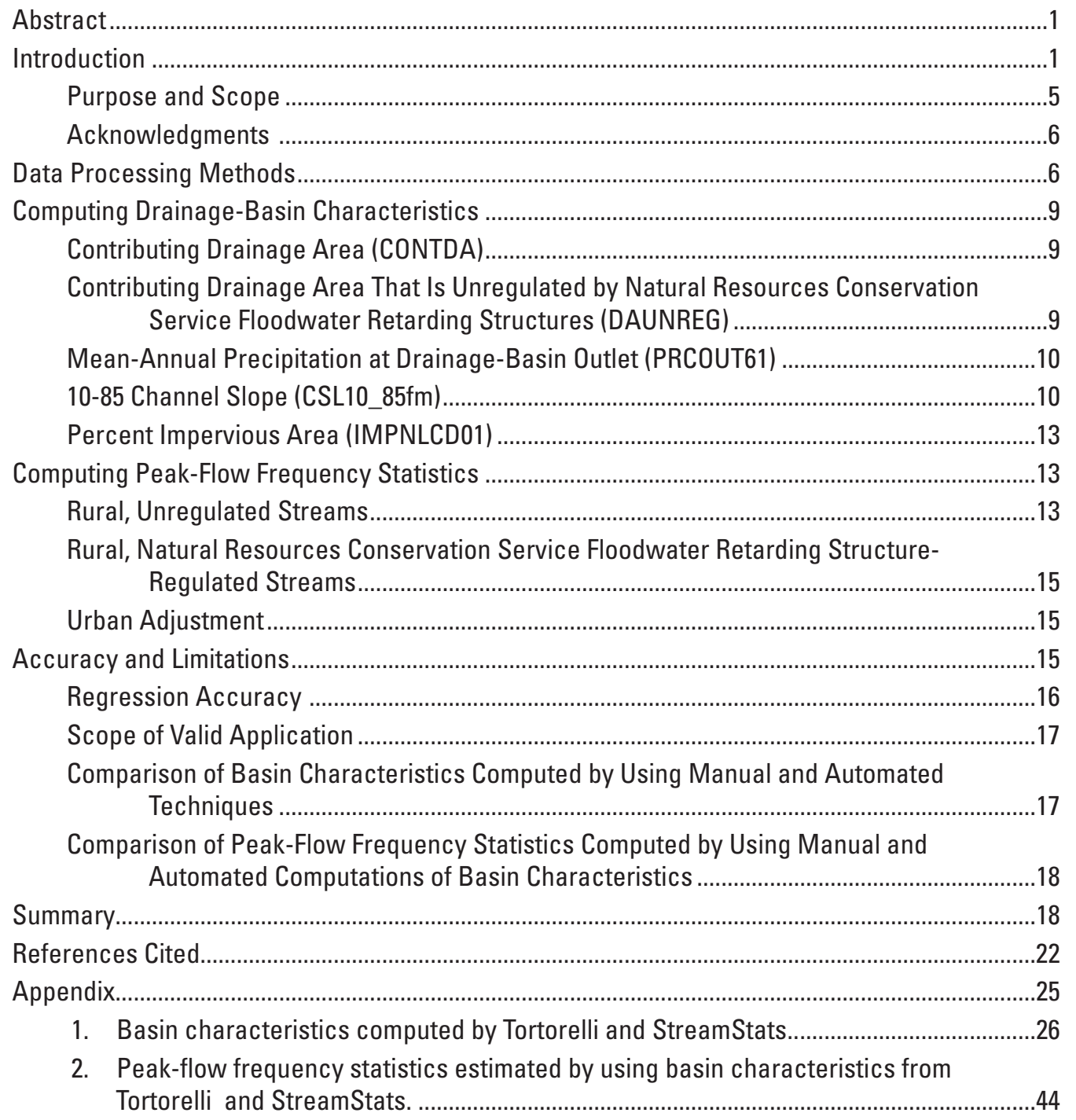

\section{Figures}

1-2. Maps showing:

1. Processed hydrologic units (HUs) for the Oklahoma StreamStats applications. ..............3

2. Processed hydrologic units and unprocessed areas for the Oklahoma StreamStats application, showing noncontributing areas and large rivers that are unavailable for computation of streamflow statistics...............................................................................

3. Flow chart illustrating the development and application of peak-flow regression equations in StreamStats

4-8. Maps showing: 
4. Elevation (National Elevation Dataset) across the Oklahoma StreamStats processed area showing selected streams from National Hydrography Dataset and selected hydrologic units from Watershed Boundary Dataset.

5. Location of Natural Resources Conservation Service floodwater retarding structures in processed areas and major dams in Oklahoma.

6. Mean-annual precipitation for the period 1961-1990 in processed area........................11

7. Example computation of $10-85$ channel slope in a hypothetical drainage basin............12

8. Impervious areas, in percent, in the Oklahoma StreamStats processed area................14

9. Graph showing urban adjustment factor (RL) showing effect of urbanization on mean-annual flood for a 1-square-mile drainage area...................................................16

10. Map showing location of 208 of 251 gages used to construct peak-flow regression equations.

11-12. Graphs showing:

11. Comparison of basin characteristics, which were mostly computed by using manual techniques at a variety of map scales, and StreamStats, which were computed by using automated techniques on 1:24,000 scale data.

12. Comparison of peak-flow frequency statistics estimated by using basin characteristics at gaged sites.

\section{Tables}

1. Description of basin characteristics used in the Oklahoma StreamStats application.

2. R-squared and standard error of regression equations for unregulated streams..........17

3. Ranges of validity for basin characteristics (independent variables) used in computation of peak-flow frequency statistics in Oklahoma. 


\section{Conversion Factors}

\begin{tabular}{|c|c|c|}
\hline Multiply & By & To obtain \\
\hline \multicolumn{3}{|c|}{ Length } \\
\hline inch (in.) & 2.54 & centimeter $(\mathrm{cm})$ \\
\hline inch (in.) & 25.4 & millimeter $(\mathrm{mm})$ \\
\hline foot $(\mathrm{ft})$ & 0.3048 & meter $(\mathrm{m})$ \\
\hline mile (mi) & 1.609 & kilometer $(\mathrm{km})$ \\
\hline \multicolumn{3}{|c|}{ Area } \\
\hline square mile $\left(\mathrm{mi}^{2}\right)$ & 259.0 & hectare (ha) \\
\hline square mile $\left(\mathrm{mi}^{2}\right)$ & 2.590 & square kilometer $\left(\mathrm{km}^{2}\right)$ \\
\hline \multicolumn{3}{|c|}{ Flow rate } \\
\hline cubic foot per second $\left(\mathrm{ft}^{3} / \mathrm{s}\right)$ & 0.02832 & cubic meter per second $\left(\mathrm{m}^{3} / \mathrm{s}\right)$ \\
\hline \multicolumn{3}{|c|}{ Hydraulic gradient } \\
\hline foot per mile (ft/mi) & 0.1894 & meter per kilometer $(\mathrm{m} / \mathrm{km})$ \\
\hline
\end{tabular}

\begin{tabular}{lcl}
\hline \multicolumn{1}{c}{ Multiply } & \multicolumn{1}{c}{ By } & \multicolumn{1}{c}{ To obtain } \\
\hline \multicolumn{2}{c}{ Length } \\
meter $(\mathrm{m})$ & 3.281 & foot $(\mathrm{ft})$ \\
kilometer $(\mathrm{km})$ & 0.6214 & mile $(\mathrm{mi})$ \\
\hline & \multicolumn{1}{c}{ Area } & \\
square kilometer $\left(\mathrm{km}^{2}\right)$ & $247.1 \quad$ & acre \\
square kilometer $\left(\mathrm{km}^{2}\right)$ & 0.3861 & square mile $\left(\mathrm{mi}^{2}\right)$ \\
\hline
\end{tabular}

Vertical coordinate information is referenced to the North American Vertical Datum of 1988 (NAVD 88).

Horizontal coordinate information is referenced to the North American Datum of 1983 (NAD 83). 


\title{
StreamStats in Oklahoma-Drainage-Basin Characteristics and Peak-Flow Frequency Statistics for Ungaged Streams
}

\author{
By S. Jerrod Smith and Rachel A. Esralew
}

\section{Abstract}

The USGS Streamflow Statistics (StreamStats) Program was created to make geographic information systems-based estimation of streamflow statistics easier, faster, and more consistent than previously used manual techniques. The StreamStats user interface is a map-based internet application that allows users to easily obtain streamflow statistics, basin characteristics, and other information for user-selected U.S. Geological Survey data-collection stations and ungaged sites of interest. The application relies on the data collected at U.S. Geological Survey streamflow-gaging stations, computer aided computations of drainage-basin characteristics, and published regression equations for several geographic regions comprising the United States. The StreamStats application interface allows the user to (1) obtain information on features in selected map layers, (2) delineate drainage basins for ungaged sites, (3) download drainage-basin polygons to a shapefile, (4) compute selected basin characteristics for delineated drainage basins, (5) estimate selected streamflow statistics for ungaged points on a stream, (6) print map views, (7) retrieve information for U.S. Geological Survey streamflow-gaging stations, and (8) get help on using StreamStats.

StreamStats was designed for national application, with each state, territory, or group of states responsible for creating unique geospatial datasets and regression equations to compute selected streamflow statistics. With the cooperation of the Oklahoma Department of Transportation, StreamStats has been implemented for Oklahoma and is available at http://water.usgs.gov/osw/streamstats/.

The Oklahoma StreamStats application covers 69 processed hydrologic units and most of the state of Oklahoma. Basin characteristics available for computation include contributing drainage area, contributing drainage area that is unregulated by Natural Resources Conservation Service floodwater retarding structures, mean-annual precipitation at the drainage-basin outlet for the period 1961-1990, 10-85 channel slope (slope between points located at 10 percent and 85 percent of the longest flow-path length upstream from the outlet), and percent impervious area. The Oklahoma StreamStats application interacts with the National Streamflow Statistics database, which contains the peak-flow regression equations in a previously published report. Fourteen peak-flow (flood) frequency statistics are available for computation in the Oklahoma StreamStats application. These statistics include the peak flow at 2-, 5-, 10-, 25-, 50-, 100-, and 500-year recurrence intervals for rural, unregulated streams; and the peak flow at 2-, 5-, 10-, 25-, 50-, 100-, and 500-year recurrence intervals for rural streams that are regulated by Natural Resources Conservation Service floodwater retarding structures. Basin characteristics and streamflow statistics cannot be computed for locations in playa basins (mostly in the Oklahoma Panhandle) and along main stems of the largest river systems in the state, namely the Arkansas, Canadian, Cimarron, Neosho, Red, and Verdigris Rivers, because parts of the drainage areas extend outside of the processed hydrologic units.

\section{Introduction}

Planning, permitting, design, and operation of hydraulic structures (such as dams, bridges, and culverts) depend on reliable and accurate estimates of streamflow statistics, especially peak-flow frequency statistics. The U.S. Geological Survey (USGS) periodically publishes these streamflow statistics for gaged sites in and near Oklahoma with long-term record (Tortorelli, 2002; Lewis and Esralew, 2009). Regionalized regression methods have been used in Oklahoma to estimate peak-flow (flood) frequency statistics at ungaged sites as a function of measured physical and climatic drainage-basin characteristics (Tortorelli, 1997).

The USGS Streamflow Statistics (StreamStats) Program was created cooperatively by the USGS and Environmental Systems Research Institute, Inc. (ESRI) (2007, 
http://www.esri.com), to make geographic information systems (GIS)-based estimation of streamflow statistics easier, faster, and more consistent than previously used manual techniques (Koltun and others, 2006). Prior to the development of computerized GIS techniques, drainage-basin characteristics were measured or computed from paper maps. The measurement of drainage-basin characteristics by manual methods was time consuming, inconsistent, and can be prone to error. The precision of estimates for some drainage-basin characteristics, such as contributing drainage area and channel slope, varied with the basin size and the map scale used. In addition, some manual computations of these characteristics took hours to days for large basins. GIS techniques can be used to compute drainage-basin characteristics in seconds, with greater accuracy and reproducibility than manual techniques.

The StreamStats user interface is a map-based internet application that allows users to easily obtain streamflow statistics, basin characteristics, and other information for userselected USGS streamflow-gaging stations and ungaged sites of interest (Ries and others, 2004; Ries and others, 2008). The application relies on the data collected at USGS streamflowgaging stations, computer aided computations of drainagebasin characteristics, and published regression equations for several geographic regions comprising the United States. The StreamStats application interface allows the user to (1) obtain information on map layer features, (2) delineate drainage basins for ungaged sites, (3) download drainage-basin polygons to a shapefile, (4) compute selected basin characteristics for delineated drainage basins, (5) estimate selected streamflow statistics for ungaged points on a stream, (6) print map views, (7) retrieve information for USGS streamflow-gaging stations, including published streamflow statistics at stations with longterm streamflow data, and (8) get help on using StreamStats (Ries and others, 2004; Ries and others, 2008).

The USGS StreamStats Program was designed for national application, with each state, territory, or group of states responsible for creating unique geospatial datasets and regression equations to compute streamflow statistics. With the cooperation of the Oklahoma Department of Transportation, StreamStats has now been implemented for Oklahoma and is available at http://water.usgs.gov/osw/streamstats/. The primary purpose of the Oklahoma StreamStats application in the initial version is to provide estimates of drainage-basin characteristics and peak-flow frequency statistics for user-selected ungaged sites on Oklahoma streams. Basin characteristics and peak-flow frequency statistics are used by hydrologic scientists and engineers to appropriately design structures such as roads, dams, culverts, bridges, and levees, which interact with waterways. Estimates of basin characteristics and streamflow statistics also should be useful to water-resource managers, developers, and conservationists in daily planning activities.

The Oklahoma StreamStats application covers 69 processed hydrologic units (HUs) and most of the state of Oklahoma (fig. 1). Basin characteristics available for computation include contributing drainage area, contributing drainage area that is unregulated by Natural Resources Conservation
Service (NRCS) floodwater retarding (FWR) structures, mean-annual precipitation at the drainage-basin outlet for the period 1961-1990, 10-85 channel slope (slope between points located at 10 percent and 85 percent of the longest flow-path length upstream from the outlet), and percent impervious area. Basin characteristics are valid only for drainage basins entirely in the processed area (fig. 2). Basin characteristics and streamflow statistics cannot be computed for locations in noncontributing areas (such as playa basins in the Oklahoma Panhandle) and along main stems of the largest river systems in the state, namely the Arkansas, Canadian, Cimarron, Neosho, Red, and Verdigris Rivers, because parts of the drainage basins extend outside of the processed hydrologic units (HUs) (fig. 2).

StreamStats uses a regionalized regression method to estimate streamflow statistics at ungaged sites. The regionalized regression method uses physical and climatic drainagebasin characteristics and streamflow data for gaged basins to construct regression equations relating selected basin characteristics to selected streamflow statistics. Multiple drainage-basin characteristics, such as contributing drainage area, mean-annual precipitation, and channel slope, are used as independent variables in the regression equation to estimate each streamflow statistic (dependent variable). The regression equations, created at gaged locations, then can be used to estimate streamflow statistics at ungaged stream locations in similar physical and climatic settings.

The multiple-linear regression equation takes the general form:

$Y_{i}=10^{b_{o}} *\left(X_{1}{ }^{b_{1}}\right) *\left(X_{2}^{b_{2}}\right) \ldots\left(X_{n}^{b_{n}}\right) * 10^{\varepsilon_{i}}$

where

$$
\begin{gathered}
\mathrm{Y}_{\mathrm{i}} \quad \begin{array}{c}
\text { is the value of the dependent variable, or } \\
\text { streamflow statistic, for station } \mathrm{i},
\end{array} \\
\begin{aligned}
& \mathrm{X}_{1} \text { to } \mathrm{X}_{\mathrm{n}} \begin{array}{r}
\text { are the } \mathrm{n} \text { independent variables, or series of } \\
\text { drainage-basin characteristics, }
\end{array} \\
& b_{o} \text { to } b_{n} \text { are the } \mathrm{n}+1 \text { regression-model coefficients, and } \\
& \varepsilon_{i} \text { is the residual error (difference between } \\
& \text { the observed and estimated values of the } \\
& \text { dependent variables). }
\end{aligned}
\end{gathered}
$$

In regression analysis, a least-squares method can be used to estimate the regression-model coefficients. The coefficients are determined after minimizing the sum of the squared differences, or errors, of the measured and estimated data points. Each set of basin characteristics is selected to give the best estimate for each streamflow statistic and represent the unique landscape and hydrologic conditions of the region or state for which the regression equation was created.

The basic procedure for regression equation development and application in StreamStats is presented in figure 3. First, streamflow-gaging stations (gages) with sufficiently long streamflow record (typically 10 or more years) are identified, and selected basin characteristics are computed at each gage. Next, streamflow statistics are computed for the period of record at each gage. The most statistically significant independent variables (basin characteristics) are selected 


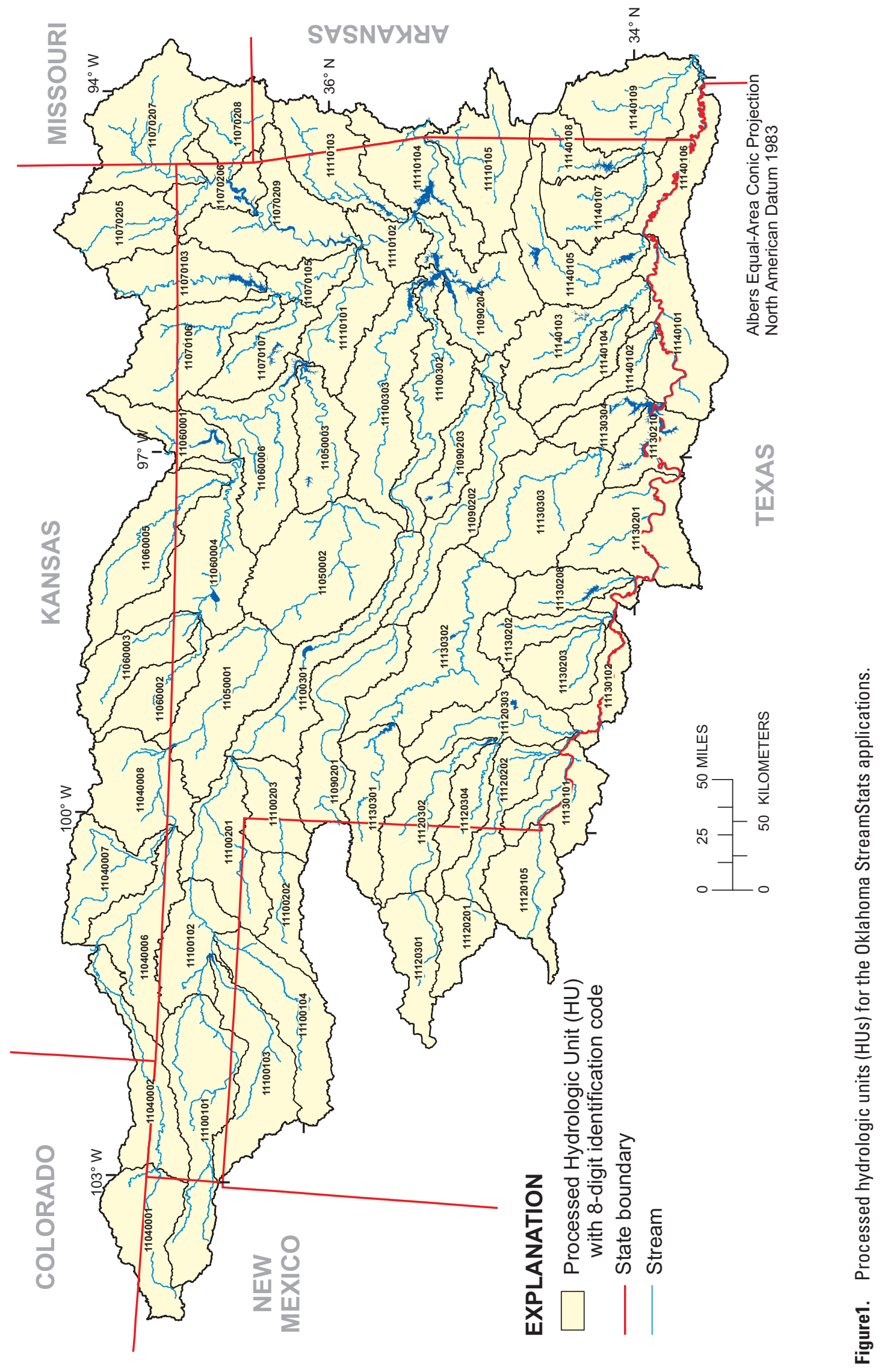




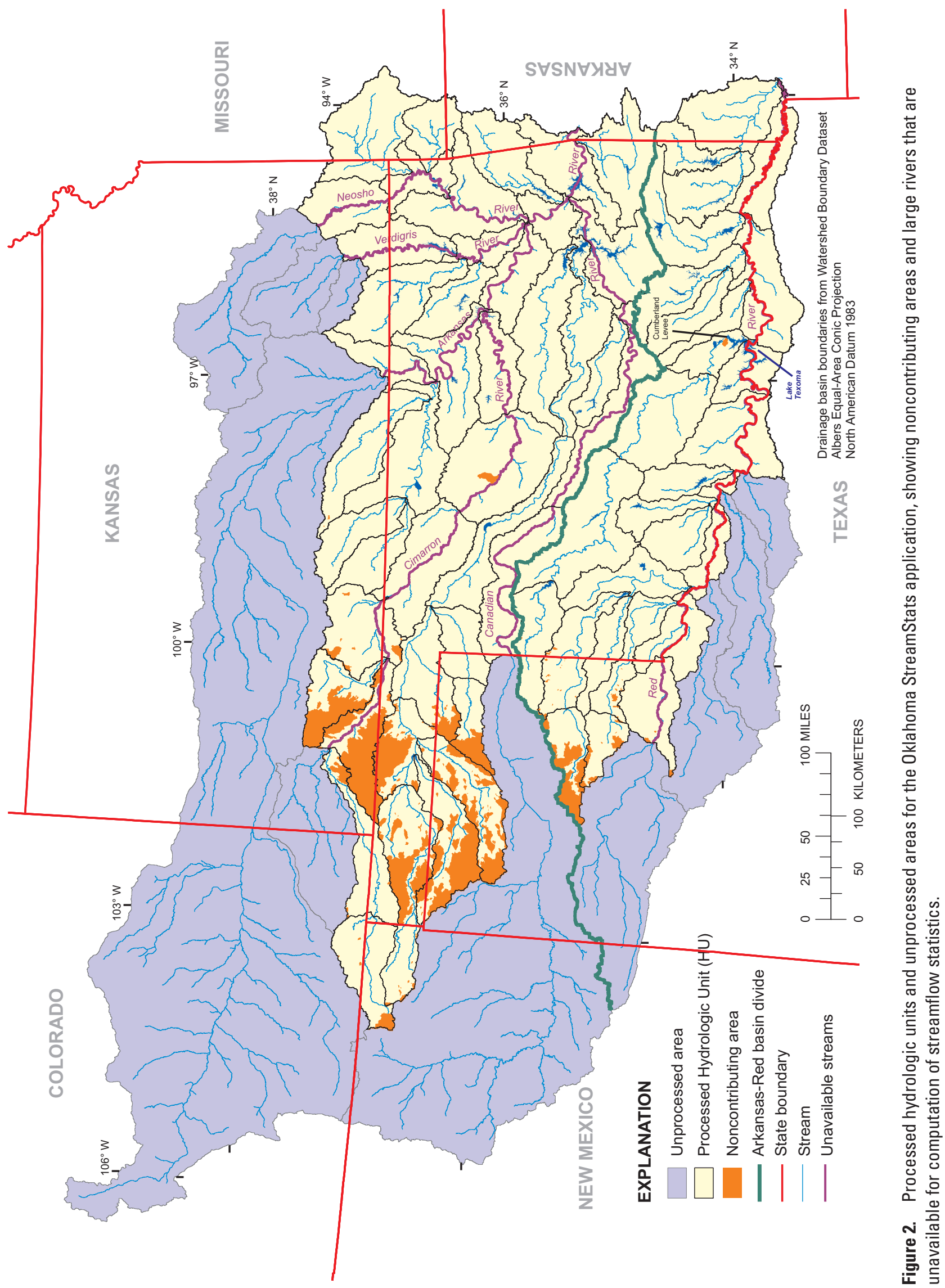




\section{At gaged locations}

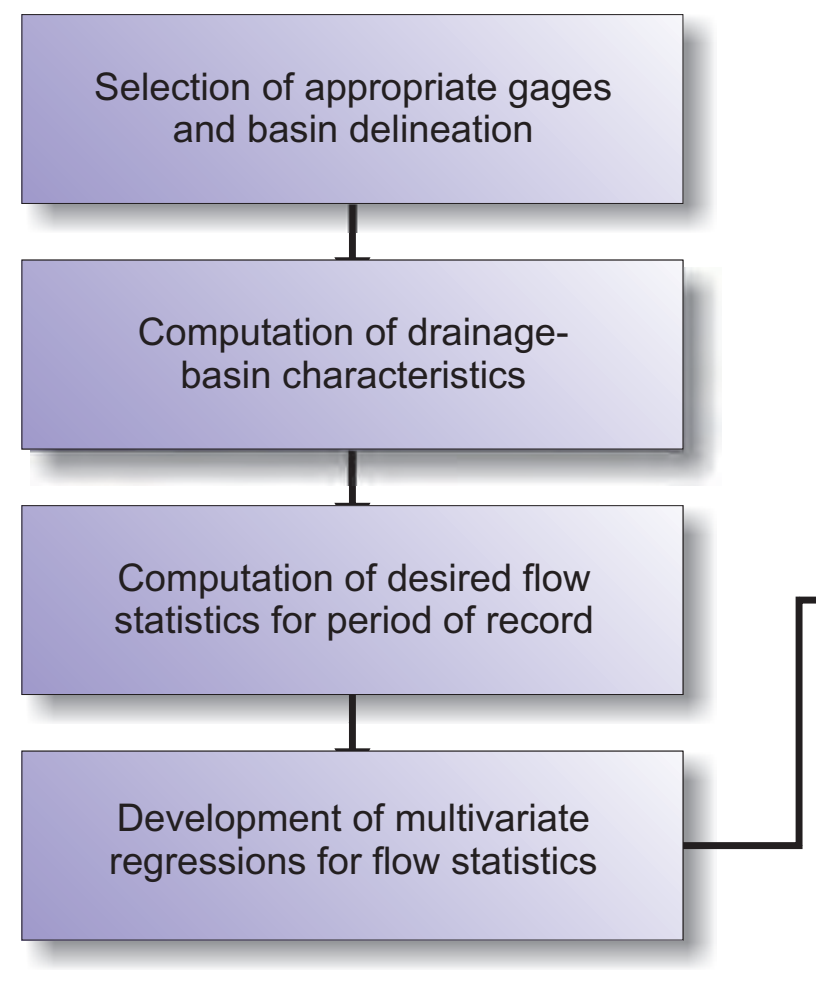

\section{At ungaged locations (in StreamStats web application)}

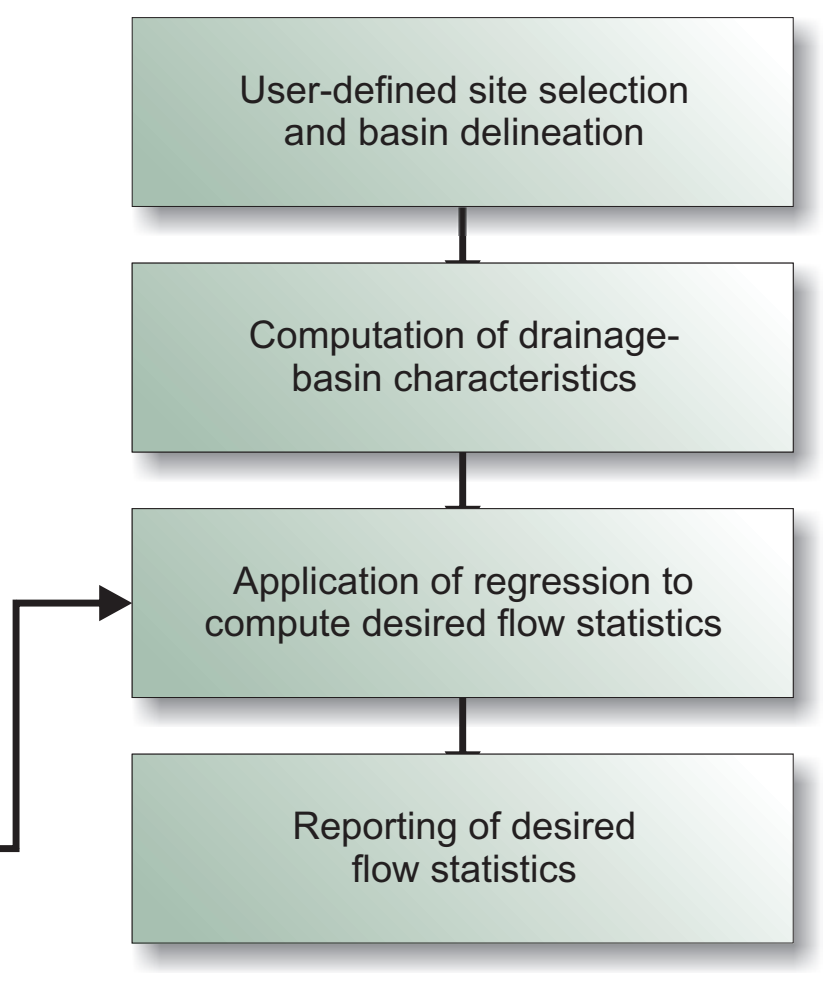

Figure 3. Flow chart illustrating the development and application of peak-flow regression equations in StreamStats.

for multivariate regression with each streamflow statistic by using sensitivity analysis and tests of collinearity. These multivariate regression equations are applied to ungaged sites in the StreamStats web application. When the StreamStats user clicks on an ungaged location on a stream, StreamStats delineates the contributing drainage basin. The application computes selected basin characteristics and applies selected regression equations to compute the user-requested streamflow statistics with a 90-percent confidence interval. The computed basin characteristics and flow statistics for the ungaged site are reported to the user.

Tortorelli (1997) created statewide regression equations for Oklahoma to estimate peak-flow frequency statistics for selected recurrence intervals $(2,5,10,25,50,100$, and 500 years). Significant independent variables required to estimate peak-flow frequency statistics for rural unregulated streams in Oklahoma are (1) contributing drainage area, (2) mean-annual precipitation for the period 1961-1990 at the drainage-basin outlet $^{1}$, and (3) 10-85 channel slope (Tortorelli, 1997). The regression equations are intended for use in rural, unregulated

\footnotetext{
${ }^{1}$ Area-weighted mean-annual precipitation did not substantially increase the accuracy of the regression equations (Tortorelli, 1997).
}

drainage basins and rural drainage basins that are regulated by NRCS FWR structures. The Tortorelli (1997) regression equations were not intended for use in heavily urbanized drainage basins or drainage basins with other types of streamflow regulation. However, Tortorelli (1997) provided a method for adjusting peak-flow frequency statistics for some urbanization effects. For ungaged sites on urban streams, an urban adjustment of the statewide regression equations for rural streams can be used to estimate peak-flow frequency statistics. This urban adjustment is not applied by the StreamStats application; proper application of the urban adjustment is the responsibility of the StreamStats user.

\section{Purpose and Scope}

The primary purpose of this report is to document the incorporation of procedures for estimating selected drainagebasin characteristics and peak-flow frequency statistics for ungaged streams from Tortorelli (1997) into the StreamStats application. The peak-flow estimation procedures created into the Oklahoma StreamStats application are optimized for rural, unregulated drainage basins entirely in Oklahoma and with 
less than 2,510 square miles $\left(\mathrm{mi}^{2}\right)$ of contributing drainage area. The peak-flow estimation procedures also can be used in basins regulated by small NRCS FWR structures with the understanding that results may be less accurate in those settings. This report also describes the development, functionality, and limitations of the USGS StreamStats application for Oklahoma, and a procedure for adjusting estimated peak-flow frequency statistics for urbanization effects.

\section{Acknowledgments}

Christine Dartiguenave, Environmental Systems Research Institute, Inc., provided software support and solutions throughout the project. The contributions of Jim Henley, Natural Resources Conservation Service, and Mike Sughru, Oklahoma Water Resources Board, were valuable in the production and refinement of digital datasets that incorporated dam locations in the state of Oklahoma.

The authors appreciate the efforts of Seth Tribbey, formerly of the U.S. Geological Survey, and Jason R. Masoner, U.S. Geological Survey, who assisted with data processing. The authors also greatly appreciate the help of Alan H. Rea and Kenneth D. Skinner, U.S. Geological Survey, who provided technical support and solutions to many problems throughout the project.

\section{Data Processing Methods}

A large part of the effort involved in implementing StreamStats surrounds creating, quality assuring, and processing geospatial datasets required to compute the independent variables (basin characteristics) used in regression equations (Koltun and others, 2006). Several publicly available national geospatial datasets were integrated, by using a process described by Rea and Skinner (2009), to compile a hydrologically correct topographic representation of the Oklahoma landscape. These national datasets included the USGS National Elevation Dataset (NED; U.S. Geological Survey, 2006), the Natural Resources Conservation Service (NRCS) Watershed Boundary Dataset (WBD; Natural Resources Conservation Service, 2006), and the USGS National Hydrography Dataset (NHD; U.S. Geological Survey, 2008) (fig. 4). Digital Elevation Models (DEMs) from the NED (fig. 4) are a combination of 10-meter (horizontal) resolution (where available) and resampled 30-meter resolution elevation data. Therefore, some areas of Oklahoma have better elevation control than others. Generally, the vertical accuracy of NED elevation data is about \pm 7 to 15 meters (http: |seamless.usgs.govlfaqlned_faq. php).

Two high-resolution datasets were integrated with the NED to limit hydrologic errors that might result from the coarse vertical resolution of NED elevation data. High-resolution NHD streams were used to reinforce the stream drainage network onto the DEM. The NHD streams are generated from streams (blue lines) on USGS 7.5-minute, 1:24,000 scale topographic maps that, in some areas, have been updated from aerial photograph inspection. Likewise, the WBD drainage divides were used to reinforce ridgelines on the DEM. Some modification of the NHD (editing stream loops) and WBD lines (adding divides to represent dams that were not built when the elevation data were collected) was necessary to more accurately represent the catchment and drainage network. All modifications to the DEM were made over a 1:24,000-scale topographic map base with occasional aerial photo verification. Rea and Skinner (2009) provide a more detailed review of processing steps.

Some areas of Oklahoma posed challenges for accurate representation in the topographic model. Though the WBD contains subbasin units based on the 8-digit HUs of the USGS (fig. 1), some of the area in these units is likely noncontributing, and does not contribute runoff to the main stem of the HU (fig. 2). For example, western Oklahoma, Kansas, and Texas have numerous playa lakes that accumulate runoff during precipitation. Accumulated runoff is slowly released from these lakes by infiltration and evapotranspiration. These lakes do not, at least directly, contribute runoff to a stream. Therefore, noncontributing areas (fig. 2) were modeled in the StreamStats application by using drains (sinks) at playa lakes and large depressions (greater than about 0.16 square kilometer in area) to subtract drainage areas from the main stem drainage area. Noncontributing areas also are excluded during computation of basin characteristics. Playa lakes or large depressions accounted for all but one of the noncontributing areas modeled in the StreamStats application; a special case was made for the area (about $12 \mathrm{mi}^{2}$ ) behind Cumberland levee on Lake Texoma in HU 11130304 (figs. 1-2). Areas behind manmade dams were not modeled as noncontributing areas because these features provide outlet works and spillways that can allow runoff to flow downstream.

The U.S. Army Corps of Engineers National Inventory of Dams (NID) dataset was modified to place NRCS FWR structures and other major Oklahoma dams (Oklahoma Water Resources Board, 2007) on the drainage network. These structure locations were verified by using National Agriculture Imagery Program (NAIP) 2003 or 2006 color aerial photography.

The processed areas of Oklahoma, Texas, Arkansas, Missouri, and Kansas contained 2,352 NRCS FWR structures when the StreamStats application for Oklahoma was designed (2007; fig. 5). Most of the FWR structures were constructed in the late 1950s and 1960s and about half are in the Washita River Basin (fig. 5). The FWR structures were constructed in small headwater catchments (as much as about $90 \mathrm{mi}^{2}$ in contributing drainage area) and were intended to protect vulnerable basins from soil erosion and flooding. The structures were designed to temporarily impound storm runoff from small headwater catchments, and slowly release the impounded water through a drop-inlet spillway over a period of several days. If the design capacity of the FWR structures is exceeded during a storm, an uncontrolled emergency spillway releases the excess storm water. When several of these structures are 


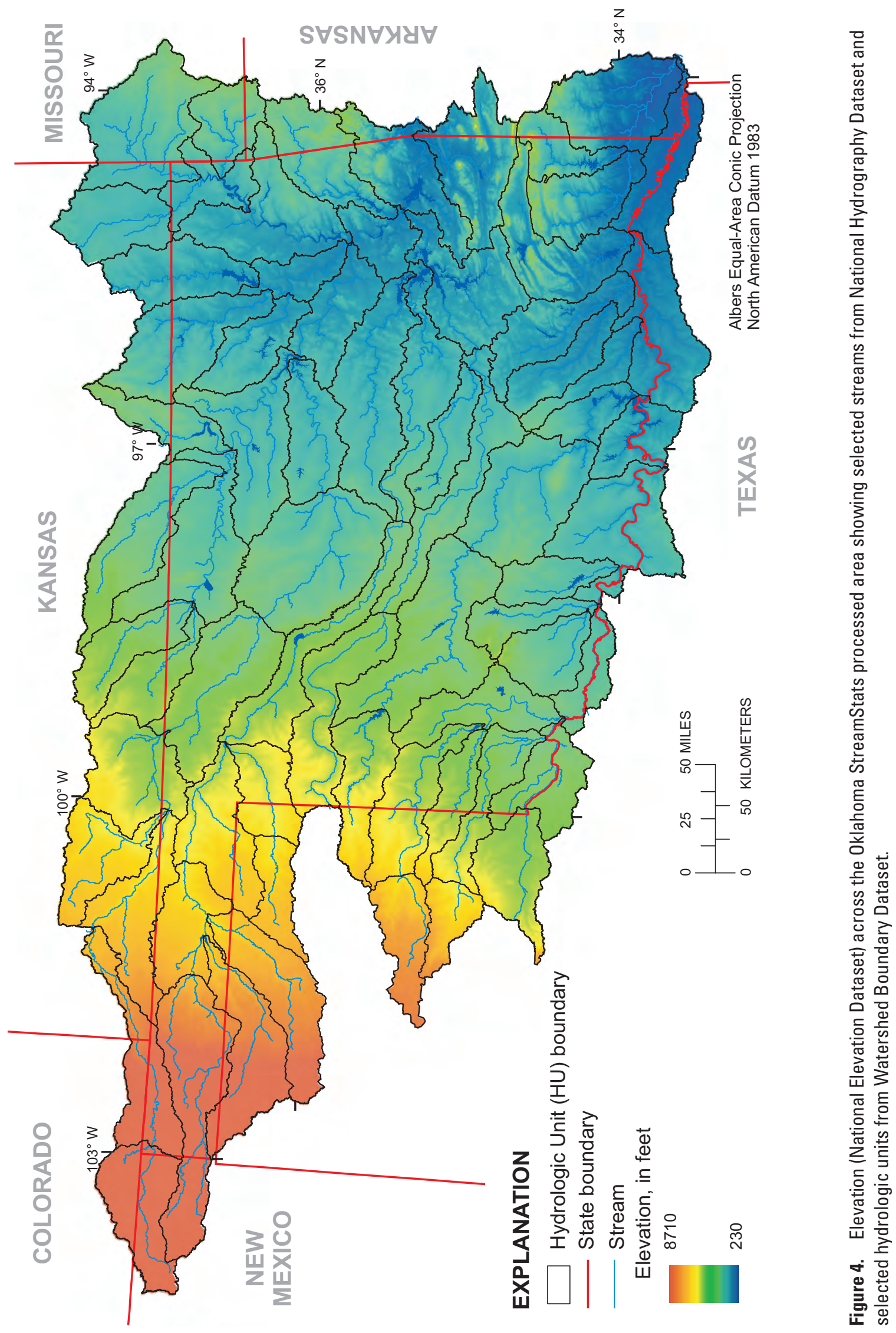




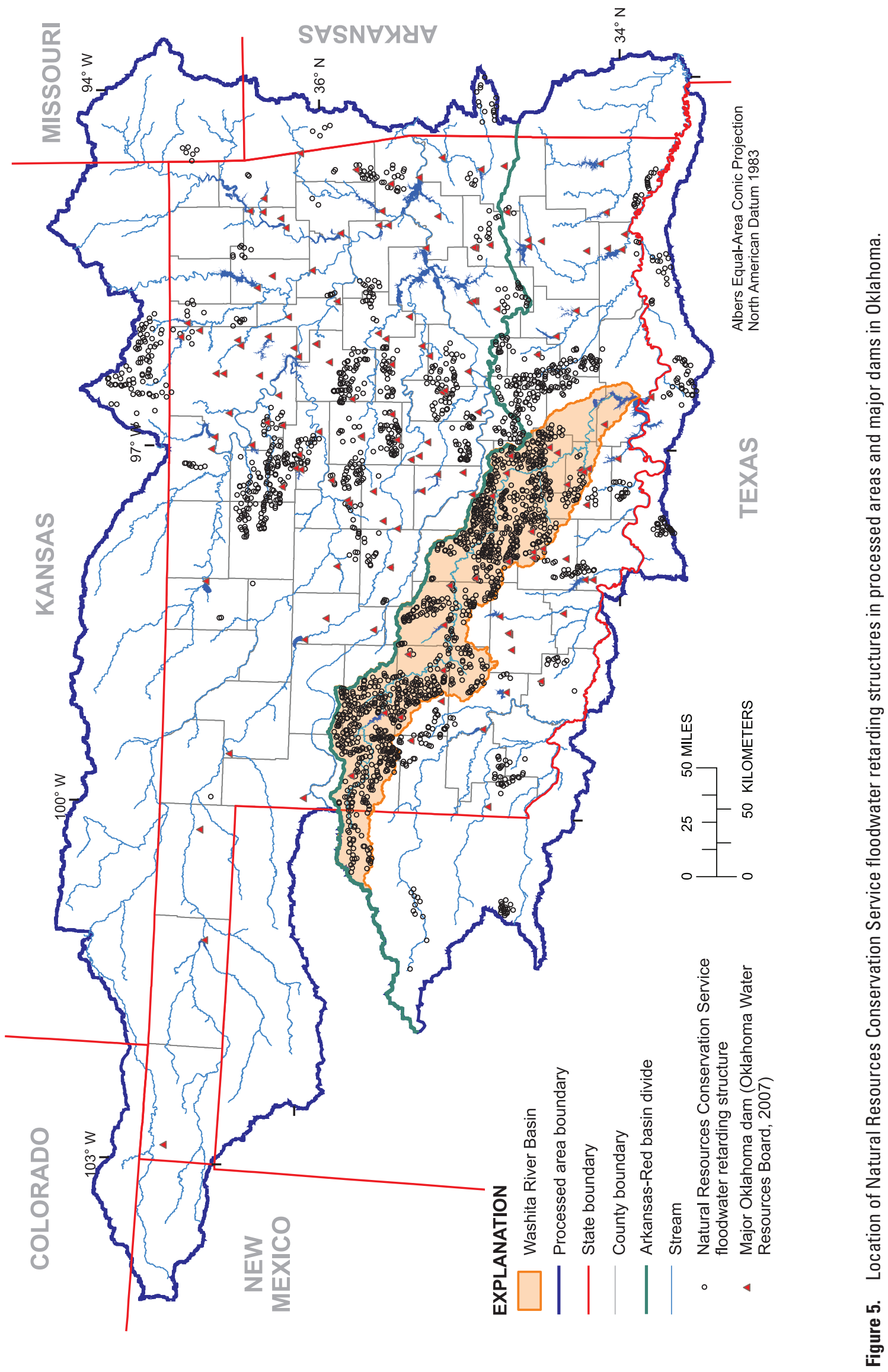


constructed as part of a basin conservation and flood-control project, the net result is a delayed and reduced peak flow downstream. However, the efficiency of these structures during any given storm is dependent on the amount of available storage.

Contributing drainage area is calculated in the GIS by using a flow-accumulation grid, which is a raster in which the number in each cell is equal to the number of upstream or upgradient cells that flow into that cell. The automated flowaccumulation function requires input of a flow-direction grid, which describes the direction of flow from each cell to the next downstream cell. A weighted flow-accumulation function was used to create a grid describing NRCS FWR structureadjusted contributing drainage area. The function uses the same flow-direction grid, but allows weighted accounting of upstream or upgradient cells on the basis of a weight grid input. The weight grid used in calculation of NRCS FWR structure-adjusted contributing drainage area contained mostly zeroes (indicating that the cell was not to be counted), but cells representing NRCS FWR structures were assigned a number equal to the upstream contributing drainage area. Because some structures were nested within the drainage area of other structures, only non-nested areas were reflected in the weight grid to avoid double counting areas. The resulting weighted flow-accumulation grid contains cell values that represent the contributing drainage area that is regulated by (upstream from) NRCS FWR structures. To obtain the contributing drainage area that is unregulated by NRCS FWR structures, this grid was simply subtracted from the unweighted contributing drainage area grid.

Other datasets were added to the Oklahoma StreamStats application to allow computation of mean-annual precipitation at the drainage-basin outlet and percent impervious area over a drainage basin. Mean-annual precipitation data for the period 1961-1990 were downloaded from the Oregon State University PRISM Climate Group as a 2-kilometer ASCII grid file (PRISM Climate Group, 2008). The impervious area NLCD data (2001) were downloaded from the Multi-Resolution Land Characteristics Consortium (2008) as a 30-meter grid. The precipitation and impervious land cover data were merged and clipped to the processed area (fig. 2) prior to inclusion into the StreamStats application.

\section{Computing Drainage-Basin Characteristics}

The Oklahoma StreamStats application was designed to automatically compute selected drainage-basin characteristics (table 1) that may influence peak-flow frequency statistics. These characteristics include contributing drainage area (in square miles) (CONTDA), mean-annual precipitation at the drainage-basin outlet for the period 1961-1990 (in inches) (PRCOUT61), and the 10-85 channel slope (in feet per mile $(\mathrm{ft} / \mathrm{mi}))\left(\mathrm{CSL} 10 \_85 \mathrm{fm}\right)$. Other states have recognized the utility of these particular characteristics in estimating peakflow frequency statistics by using the regionalized regression method. Peak-flow regression equations have been created for all 50 U.S. states and Puerto Rico; all 51 sets of regression equations use drainage area, 27 use channel slope, and 19 use mean-annual precipitation as independent variables in computations of peak-flow frequency statistics (Kernell Ries, USGS, written commun., 2002).

Other drainage-basin characteristics available for computation in the Oklahoma StreamStats application include the contributing drainage area that is unregulated by NRCS FWR structures (DAUNREG), which can be used in the estimation of peak-flow statistics for streams regulated by NRCS FWR structures, and percent impervious area (IMPNLCD01), which can be used to determine if an urban adjustment of peak-flow frequency statistics is necessary.

\section{Contributing Drainage Area (CONTDA)}

Drainage basins can be defined by a point on a stream, the basin outlet, to which all areas in the drainage basin contribute runoff. The StreamStats application takes a user-defined outlet on a stream and identifies, or delineates, the drainage basin of the stream at that location. Contributing drainage area is a conservative estimate of the runoff contributing area, in square miles, upstream from the user-selected basin outlet. In reality, the runoff contributing area is dependent on the duration and intensity of precipitation, the antecedent soil moisture and depression storage, and the permeability of earth materials over a drainage basin. Modeling these factors is beyond the current scope and capability of the Oklahoma StreamStats application.

The drainage-basin outlet and delineated drainage basin are used as the templates for estimating basin characteristics. StreamStats allows the user to download shapefiles of the drainage-basin outlet and the drainage-basin polygon with basin characteristics as attributes.

\section{Contributing Drainage Area That Is Unregulated by Natural Resources Conservation Service Floodwater Retarding Structures (DAUNREG)}

Oklahoma has more than 2,100 NRCS-managed FWR structures that were built in small headwater catchments to protect vulnerable land from soil erosion and flooding. A system of upstream FWR structures in a drainage basin protects land by reducing the magnitude (and frequency) of floods downstream from the FWR structures. The amount of reduction is related to the percentage of the drainage basin that is regulated by (upstream from) FWR structures (Tortorelli, 1997)

To illustrate the effectiveness of NRCS FWR structures in reducing peak flows, Oklahoma NRCS FWR structure-regulated peak-flow regression equations use an adjusted con- 
Table 1. Description of basin characteristics used in the Oklahoma StreamStats application.

[NED, National Elevation Dataset; NHD, National Hydrography Dataset; WBD, Watershed Boundary Dataset; PRISM, Parameter-Elevation Regressions on Independent Slopes Model; NRCS, Natural Resources Conservation Service; FWR, floodwater retarding]

\begin{tabular}{|c|c|c|}
\hline Basin characteristic (identifier) & Description & Data Source \\
\hline Contributing drainage area $(C O N T D A)$ & Contributing drainage area, in square miles & $\begin{array}{l}\text { NED 10-meter resolution elevation data } \\
\text { (http://seamless.usgs.gov/index.php), } \\
\text { NHD (http://nhdgeo. usgs.gov/viewer.htm, } \\
\text { accessed July 2006) and WBD (source: } \\
\text { http://www.ncgc.nrcs.usda.gov/products/ } \\
\text { datasets/watershed/, accessed July 2006) }\end{array}$ \\
\hline $\begin{array}{l}\text { Percentage NRCS FWR structure-regulated } \\
\text { contributing drainage area (NRCSPCT) }\end{array}$ & $\begin{array}{l}\text { Contributing drainage area that is regulated } \\
\text { by NRCS FWR structures, in percent }\end{array}$ & $\begin{array}{l}\text { Derived; [(CONTDA - DAUNREG }) / \\
\text { CONTDA }]\end{array}$ \\
\hline $\begin{array}{l}\text { Mean-annual precipitation at basin outlet } \\
\quad(\text { PRCOUT61) }\end{array}$ & $\begin{array}{l}\text { Mean-annual precipitation (1961-1990) at } \\
\text { the basin outlet, in inches }\end{array}$ & $\begin{array}{l}\text { 1,600-meter resolution data layer created } \\
\text { from PRISM dataset. Source: } h t t p: / / w w w . \\
\text { prism.oregonstate.edu/, accessed July } \\
2008\end{array}$ \\
\hline Percent impervious area (IMPNLCD01) & $\begin{array}{l}\text { Percentage of basin surface area containing } \\
\text { impervious cover }\end{array}$ & $\begin{array}{l}\text { 30-meter resolution data layer from the } \\
\text { Multi-Resolution Land Characteristics } \\
\text { Consortium, accessed August } 2008 .\end{array}$ \\
\hline
\end{tabular}

tributing drainage area that excludes area regulated by FWR structures. The contributing drainage area that is unregulated by NRCS FWR structures (DAUNREG) is reported in units of square miles. Other basin characteristics used to estimate NRCS FWR structure-regulated peak-flow frequency statistics, such as 10-85 channel slope and percent impervious area, are estimated over the contributing drainage area (CONTDA), which includes areas regulated by NRCS FWR structures. Area regulated by NRCS FWR structures also is reported by the StreamStats application. This basin characteristic (NRCSPCT), reported as percent, is computed as the contributing drainage area regulated by NRCS FWR structures divided by the contributing drainage area,

\section{NRCSPCT $=[($ CONTDA - DAUNREG $) /$ CONTDA $]$}

where contributing drainage area (CONTDA) and contributing drainage area that is unregulated by NRCS FWR structures (DAUNREG) are in units of square miles. The data used to compute DAUNREG and NRCSPCT were current as of 2006. The user should be aware that NRCS FWR structures constructed or removed since 2006 may not be represented in StreamStats.

\section{Mean-Annual Precipitation at Drainage-Basin Outlet (PRCOUT61)}

Tortorelli (1997) found the mean-annual precipitation at the drainage-basin outlet (PRCOUT61) to be as useful as mean-annual area-weighted basin precipitation as an independent variable in peak-flow regressions. Mean-annual precipitation data for the period 1961 to 1990 (Daly and others, 1994; PRISM Climate Group, 2008) were used to define precipitation at the drainage-basin outlet. The computed mean-annual precipitation at the drainage-basin outlet is reported in units of inches (fig. 6).

\section{0-85 Channel Slope (CSL10_85fm)}

Channel slope can be computed in several ways. The Oklahoma StreamStats application computes channel slope by using the 10-85 channel slope method described in Tortorelli (1997). This method first identifies the longest flow path from the basin outlet to the drainage divide (fig. 7). The total length of this flow path (L) is measured from the outlet, and reference points are placed at locations that are 10 and 85 percent of the length of the flow path (fig. 7). The 10-85 channel slope 


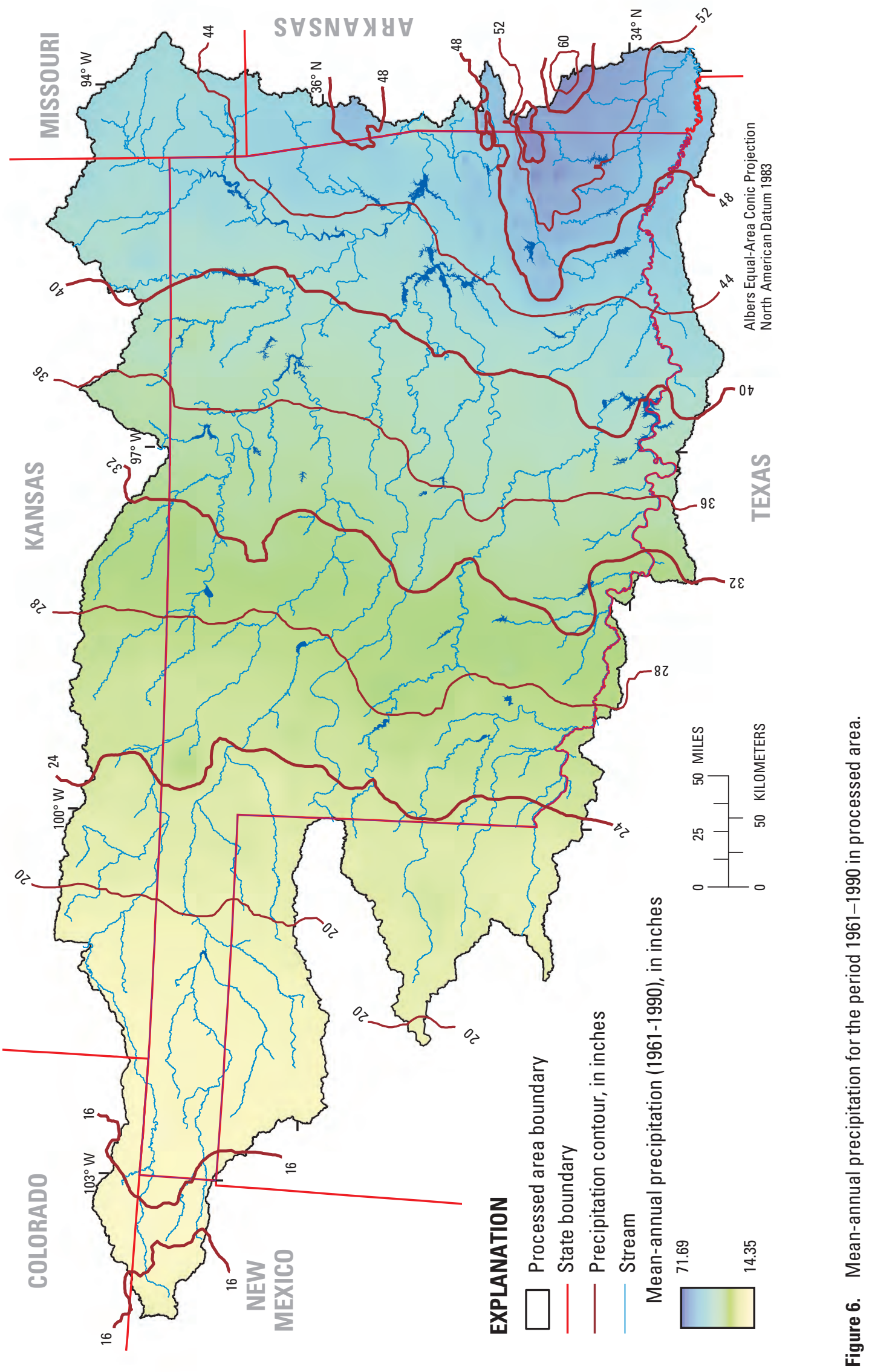




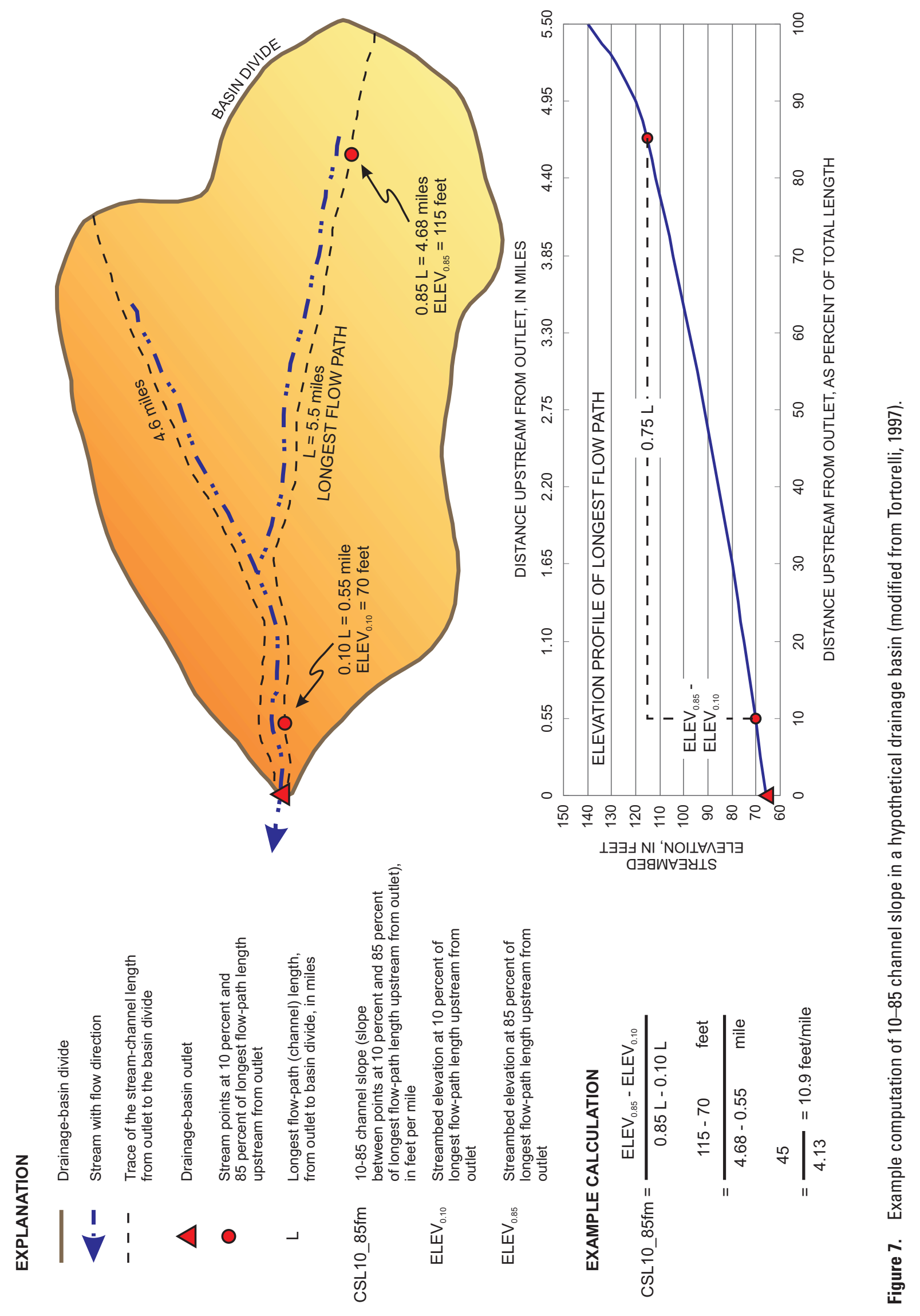


(CSL10 $85 \mathrm{fm}$ ) is then computed by dividing the difference in elevation ( $\triangle E L E V)$ between the two points by the stream length $(0.75 \mathrm{~L})$ between the two points (fig. 7). The computed slope is reported in units of feet per mile. StreamStats allows the user to download shapefiles of the longest flow path and the 10 percent and 85 percent points used to compute the 1085 channel slope.

The 10-85 channel slope is more sensitive to map scale effects than are other basin characteristics used in the estimation of Oklahoma peak-flow frequency statistics. When 10-85 channel slope is computed from paper maps, the length of the longest flow path is usually underestimated. The estimation bias is a result of the loss of stream sinuosity (and stream length) that typically occurs at smaller (zoomed-out) ratio map scales (Mandelbrot, 1983). Tortorelli (1997) computed $10-85$ channel slopes by hand on paper maps ranging in scale from 1:24,000 to 1:250,000. The automated slope computation procedures used in StreamStats are based on the manual computation procedures used by Tortorelli (1997). However, the automated computations generally should be more precise than manual measurements (Tortorelli, 1997) because the Oklahoma StreamStats slope computations are performed exclusively on 1:24,000-scale data.

\section{Percent Impervious Area (IMPNLCD01)}

Peak flows can be augmented by urbanization in the drainage area of a stream. Urbanization tends to increase the amount of impervious surface and decrease the amount of small depression storage. The net effect is an earlier and increased peak flow downstream (Konrad, 2003). The Oklahoma StreamStats application, to support a documented procedure for adjusting peak-flow frequency statistics for urbanized areas (Tortorelli, 1997), allows computation of percent impervious area (IMPNLCD01) as a drainage-basin characteristic. Percent impervious area was not used as an independent variable in the peak-flow regressions, but this basin characteristic is useful when performing urban adjustments of peak-flow frequency statistics (see Urban Adjustment section).

The computation of percent impervious area uses the 2001 National Land Cover Database (NLCD) Impervious Surface derivative (Multi-Resolution Land Characteristics Consortium, 2008; fig. 8). The 2001 NLCD Impervious Surface derivative is a 30 -meter resolution raster dataset classified into integer percent values $(0-100)$ representing the percentage of each cell that is impervious (fig. 8). These values are simply averaged over a delineated drainage basin to compute the percentage of the basin that is impervious. Most drainage basins in Oklahoma will contain less than 1 percent impervious area, but percent impervious area can exceed 60 percent for small urban drainage basins in downtown Oklahoma City and Tulsa (fig. 8).

\section{Computing Peak-Flow Frequency Statistics}

The Oklahoma StreamStats application interacts with the National Streamflow Statistics database (U.S. Geological Survey, 2009), which contains the peak-flow regression equations published by Tortorelli (1997). Fourteen peak-flow (flood) frequency statistics are available for computation in the Oklahoma StreamStats application. These statistics include the peak flow at 2-, 5-, 10-, 25-, 50-, 100-, and 500-year recurrence intervals for rural, unregulated streams; and the peak flow at 2-, 5-, 10-, 25-, 50-, 100-, and 500-year recurrence intervals for rural streams that are regulated by NRCS FWR structures. When a user selects one or more statistics for computation, the required basin characteristics (independent variables) are computed automatically. All 14 peak-flow frequency statistics require the computation of (1) contributing drainage area (CONTDA) or contributing drainage area that is unregulated by NRCS FWR structures (DAUNREG), (2) outlet mean-annual precipitation (PRCOUT61), and (3) 10-85 channel slope (CSL10_85fm).

\section{Rural, Unregulated Streams}

The following regression equations, based on Tortorelli (1997), are used to estimate peak-flow statistics in rural, unregulated Oklahoma streams:

$$
\begin{aligned}
& \text { PK2 }=0.075(\text { CONTDA })^{0.615}(\text { CSL10_85fm })^{0.159}(\text { PRCOUT61 })^{2.103} \\
& \text { PK5 }=0.799(\text { CONTDA })^{0.616}(\text { CSL10_85fm })^{0.173}(\text { PRCOUT61 })^{1.637} \\
& \text { PK10 }=2.62(\text { CONTDA })^{0.615}(\text { CSL10_85fm })^{0.181}(\text { PRCOUT61 })^{1.404} \\
& \text { PK25 }=8.80(\text { CONTDA })^{0.614}(\text { CSL10_85fm })^{0.190}(\text { PRCOUT61 })^{1.171} \\
& \text { PK50 }=18.6(\text { CONTDA })^{0.614}(\text { CSL10_85fm })^{0.197}(\text { PRCOUT61 })^{1.029} \\
& \text { PK100 }=35.6(\text { CONTDA })^{0.614}(\text { CSL10_85fm })^{0.202}(\text { PRCOUT61 })^{0.907} \\
& \text { PK500 }=126(\text { CONTDA })^{0.612}(\text { CSL10_85fm })^{0.213}(\text { PRCOUT61 })^{0.674}
\end{aligned}
$$

The estimated peak-flow statistics at 2-, 5-, 10-, 25-, 50-, $100-$, and 500-year recurrence intervals for rural, unregulated streams (PK2 - PK500) are reported in units of cubic feet per second. Contributing drainage area (CONTDA) is in units of square miles, 10-85 channel slope (CSL10_85fm) is in units of feet per mile, and mean-annual precipitation for the period 1961-1990 at the outlet (PRCOUT61) is in units of inches. 


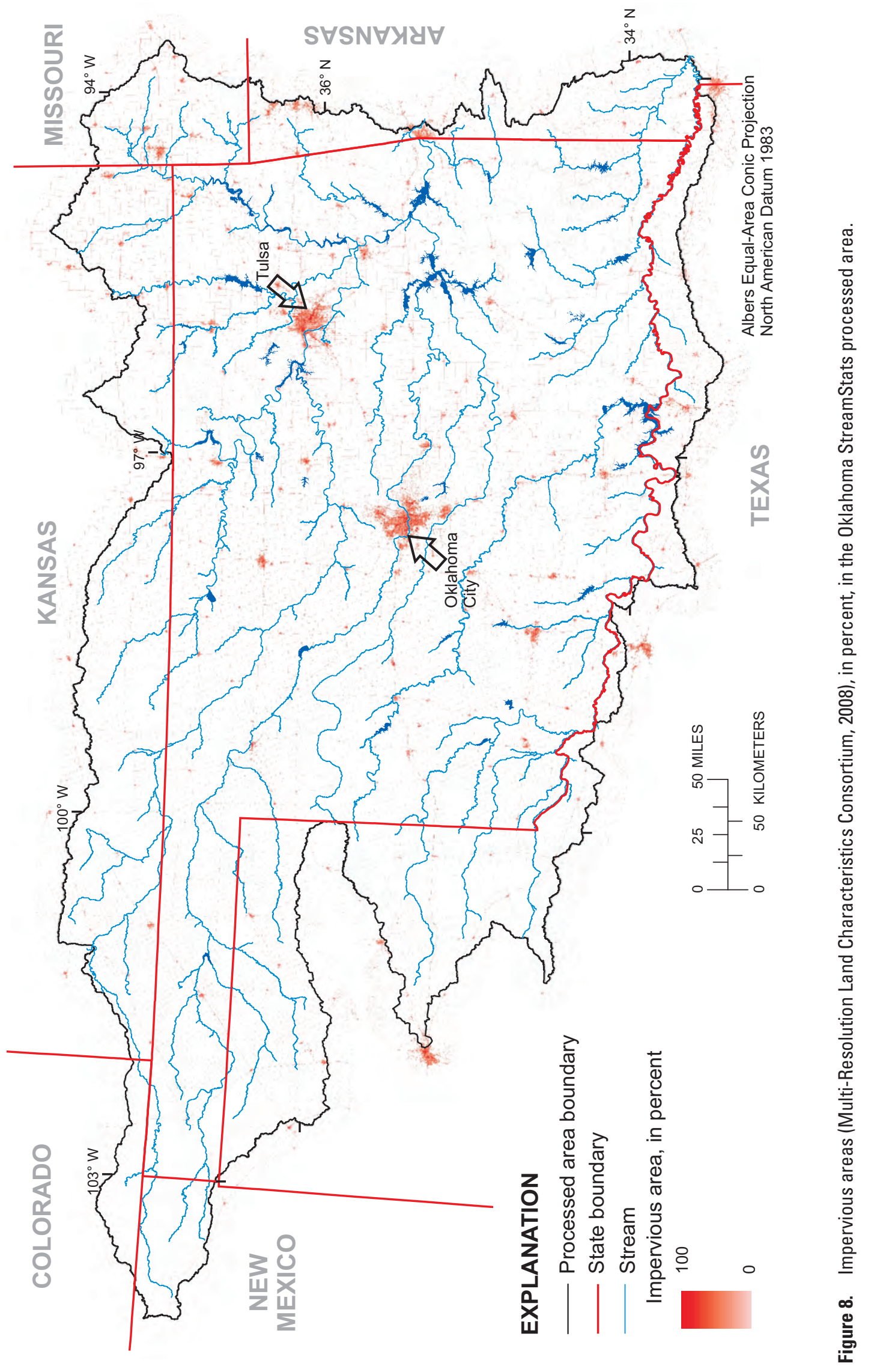




\section{Rural, Natural Resources Conservation Service Floodwater Retarding Structure-Regulated Streams}

For rural streams that are partially regulated by NRCS FWR structures, only the unregulated contributing drainage area (that which is downstream from FWR structures) is likely to contribute to peak flows ( $\left.\mathrm{PK} 2_{(\mathrm{FWR})}-\mathrm{PK} 500_{(\mathrm{FWR})}\right)$. The peakflow regression equations for rural streams regulated by NRCS FWR structures are the same as for rural, unregulated streams, except the contributing drainage area that is unregulated by NRCS FWR structures (DAUNREG) is substituted for the contributing drainage area (CONTDA). This substitution is only valid (1) if the percentage of contributing drainage area regulated by NRCS FWR structures (NRCSPCT) is less than 86 percent (Tortorelli and Bergman, 1985; Tortorelli, 1997), and (2) under the assumption that drainage areas upstream from NRCS FWR structures do not substantially contribute to the magnitude of peak flows downstream.

The following regression equations, based on Tortorelli (1997), are used to estimate peak-flow statistics in rural Oklahoma streams regulated by NRCS FWR structures:

$$
\begin{aligned}
& \text { PK2 } 2_{(\mathrm{FWR})}=0.075(\mathrm{DAUNREG})^{0.615}\left(\mathrm{CSL} 10 \_85 \mathrm{fm}\right)^{0.159}(\mathrm{PRCOUT} 61)^{2.103} \\
& \mathrm{PK} 5_{(\mathrm{FWR})}=0.799(\mathrm{DAUNREG})^{0.616}\left(\mathrm{CSL} 10 \_85 \mathrm{fm}\right)^{0.173}(\mathrm{PRCOUT} 61)^{1.637}
\end{aligned}
$$$$
\mathrm{PK} 10_{(\mathrm{FWR})}=2.62(\mathrm{DAUNREG})^{0.615}\left(\mathrm{CSL} 10 \_85 \mathrm{fm}\right)^{0.181}(\mathrm{PRCOUT} 61)^{1.404}
$$

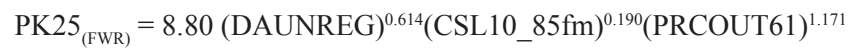$$
\mathrm{PK}_{50}(\mathrm{FWR})=18.6(\mathrm{DAUNREG})^{0.614}\left(\mathrm{CSL} 10 \_85 \mathrm{fm}\right)^{0.197}(\mathrm{PRCOUT61})^{1.029}
$$$$
\mathrm{PK}_{100}{ }_{(\mathrm{FWR})}=35.6(\mathrm{DAUNREG})^{0.614}\left(\mathrm{CSL} 10 \_85 \mathrm{fm}\right)^{0.202}(\mathrm{PRCOUT} 61)^{0.907}
$$$$
\mathrm{PK} 500_{(\mathrm{FWR})}=126(\mathrm{DAUNREG})^{0.612}\left(\mathrm{CSL} 10 \_85 \mathrm{fm}\right)^{0.213}(\mathrm{PRCOUT} 61)^{0.674}
$$

The estimated peak-flow statistics at 2-, 5-, 10-, 25-, $50-, 100-$, and 500-year recurrence intervals for rural streams regulated by NRCS FWR structures (PK2 $\left.2_{(\mathrm{FWR})}-\mathrm{PK} 500_{(\mathrm{FWR})}\right)$ are reported in units of cubic feet per second. Contributing drainage area that is unregulated by NRCS FWR structures (DAUNREG) is in units of square miles, 10-85 channel slope (CSL10_85fm) is in units of feet per mile, and meanannual precipitation for the period 1961-1990 at the outlet (PRCOUT61) is in units of inches.

\section{Urban Adjustment}

The percent impervious area and percentage of area served by storm sewers can be used to estimate an urban adjustment factor $\left(\mathrm{R}_{\mathrm{L}}\right)$ for peak streamflow by using a graphical method developed by Leopold (1968) (fig. 9). The $\mathrm{R}_{\mathrm{L}}$ is the ratio of the mean-annual flood in urban basins to the meanannual flood in rural basins. Sauer (1974) created equations to adjust peak-flow frequency statistics for urban effects in Oklahoma basins by using the $\mathrm{R}_{\mathrm{L}}$ :

$$
\begin{aligned}
& \mathrm{PK} 2_{\text {(urban) }}=\left(\mathrm{R}_{\mathrm{L}}\right) \mathrm{PK} 2 \\
& \mathrm{PK} 5_{\text {(urban) }}=1.60\left(\mathrm{R}_{\mathrm{L}}-1\right) \mathrm{PK} 2+0.167\left(7-\mathrm{R}_{\mathrm{L}}\right) \mathrm{PK} 5 \\
& \mathrm{PK} 10_{\text {(urban) }}=1.87\left(\mathrm{R}_{\mathrm{L}}-1\right) \mathrm{PK} 2+0.167\left(7-\mathrm{R}_{\mathrm{L}}\right) \mathrm{PK} 10 \\
& \mathrm{PK} 25_{\text {(urban) }}=2.21\left(\mathrm{R}_{\mathrm{L}}-1\right) \mathrm{PK} 2+0.167\left(7-\mathrm{R}_{\mathrm{L}}\right) \mathrm{PK} 25 \\
& \mathrm{PK} 50_{\text {(urban) }}=2.46\left(\mathrm{R}_{\mathrm{L}}-1\right) \mathrm{PK} 2+0.167\left(7-\mathrm{R}_{\mathrm{L}}\right) \mathrm{PK} 50 \\
& \mathrm{PK} 100_{\text {(urban) }}=2.72\left(\mathrm{R}_{\mathrm{L}}-1\right) \mathrm{PK} 2+0.167\left(7-\mathrm{R}_{\mathrm{L}}\right) \mathrm{PK} 100 \\
& \mathrm{PK} 500_{\text {(urban) }}=3.30\left(\mathrm{R}_{\mathrm{L}}-1\right) \mathrm{PK} 2+0.167\left(7-\mathrm{R}_{\mathrm{L}}\right) \mathrm{PK} 500
\end{aligned}
$$

The estimated peak-flow statistics at 2-, 5-, 10-, 25-, 50-, 100-, and 500-year recurrence intervals for urban (PK2 ${ }_{\text {(urban) }}-$ PK500 (urban) ${ }_{\text {) }}$ and rural streams (PK2 - PK500) are reported in cubic feet per second.

StreamStats can be used to compute an estimate of the percent impervious area in each delineated drainage basin, but computation of the percentage of area served by storm sewers requires local knowledge in a basin and cannot easily be estimated by using current GIS techniques. Currently (2010), urban adjustments were not applied by the Oklahoma StreamStats application. Proper estimation and application of the urban adjustment factor are the responsibility of the StreamStats user.

\section{Accuracy and Limitations}

The regression equations incorporated into StreamStats can be used to estimate peak-flow frequency statistics, but the true values of those statistics are unknown. The following sections describe the uncertainty, accuracy, and constraints associated with peak-flow frequency statistics estimated by using the Oklahoma StreamStats application. 


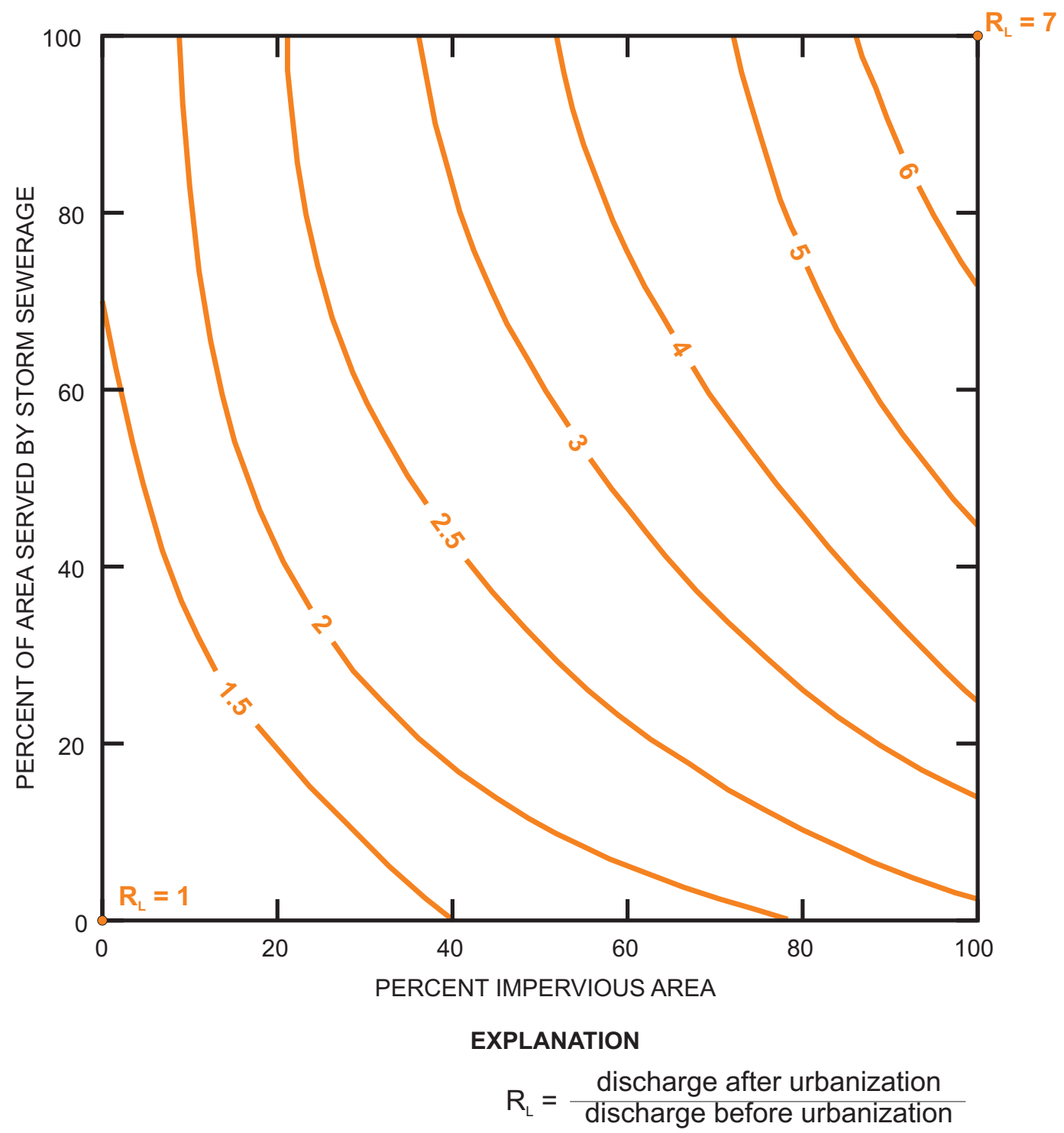

Figure 9. Urban adjustment factor $\left(R_{L}\right)$ showing effect of urbanization on mean-annual flood for a 1-square-mile drainage area (modified from Leopold, 1968).

\section{Regression Accuracy}

The accuracy of regression equations can be evaluated by using performance metrics such as the adjusted R-squared and the standard error. Performance metrics from regression equations used to estimate peak-flow frequency statistics are listed in table 2 and are from Tortorelli (1997). The adjusted $\mathrm{R}$-squared, or the adjusted coefficient of determination, is a measure of the percentage of the variation explained by the independent variables of the regression and ranges from 0 to 1.0. The adjusted R-squared is adjusted on the basis of the degrees of freedom in the regression and penalizes regressions that use an excess number of independent variables. Adjusted
$\mathrm{R}$-squared evaluates the random error of the estimates. The greater the R-squared, the greater the probability that the regression equation will accurately estimate the dependent variable

The standard error of the estimate, which can be expressed in original units, log units, or as a percent, measures the deviation between the measured and estimated data points used to build the regression equation. The standard error of the estimate is the average of all the residual values (the distance between the measured data point and the estimated data point from the regression) divided by the degrees of freedom of the regression. The standard error also can be expressed in terms of equivalent years of record, which is the number of years of 
Table 2. R-squared and standard error of regression equations for unregulated streams (Tortorelli, 1997).

[equivalent years of record, the number of years of streamflow record that is needed at an ungaged site to provide an estimate equal in accuracy to the standard error of the regression equation]

\begin{tabular}{ccccc}
\hline $\begin{array}{c}\text { Recurrence interval in } \\
\text { years }\end{array}$ & Adjusted R-squared & $\begin{array}{c}\text { Weighted standard error } \\
\text { of estimate (log10 units) }\end{array}$ & $\begin{array}{c}\text { Weighted standard error } \\
\text { of estimate (percent) }\end{array}$ & $\begin{array}{c}\text { Equivalent years of } \\
\text { record }\end{array}$ \\
\hline 2 & 0.8780 & 0.2373 & 59 & 3 \\
5 & 0.9099 & 0.1937 & 47 & 5 \\
10 & 0.9141 & 0.1846 & 45 & 8 \\
25 & 0.9108 & 0.1864 & 45 & 11 \\
50 & 0.9035 & 0.1929 & 47 & 13 \\
100 & 0.8933 & 0.2026 & 49 & 14 \\
500 & 0.8605 & 0.2331 & 58 & 14 \\
\hline
\end{tabular}

streamflow record that is needed at an ungaged site to provide an estimate equal in accuracy to the standard error of the regression equation (Tortorelli, 1997).

\section{Scope of Valid Application}

The Tortorelli (1997) peak-flow regression equations for rural, unregulated streams are only valid for drainage basins with characteristics that are in the range of characteristics used to create the regressions. For example, the regression equations should not be applied in basins where drainage area is greater than $2,510 \mathrm{mi}^{2}$ or less than $0.144 \mathrm{mi}^{2}$ (table 3). Constraints on other basin characteristics appear in table 3 .

\section{Comparison of Basin Characteristics Computed by Using Manual and Automated Techniques}

Forty-three of the 251 gages used by Tortorelli (1997) to construct the 14 peak-flow regression equations were outside of the StreamStats processed HUs (fig. 2). For the remaining 208 gages (fig. 10), basin characteristics computed by using StreamStats were compared to basin characteristics computed manually by Tortorelli (1997) (appendix 1). For contributing drainage area (CONTDA), which is generally the most influential variable in the regression equations, the two estimates were nearly equal at most sites (fig. 11); 53 percent of the StreamStats computed contributing areas were greater and 47 percent were lesser than variables computed by Tortorelli (1997). Computations of mean-annual precipitation at the drainage-basin outlet (PRCOUT61) in StreamStats also were in close agreement with computations of Tortorelli (1997) (fig. 11); 53 percent of the StreamStats computed precipitation values were greater and 47 percent were lesser than computations done by Tortorelli (1997).

StreamStats automated computations of 10-85 channel slope (CSL10_85fm) tend to be slightly less than the manual computations of Tortorelli (1997); 24 percent of the Stream-
Stats computed 10-85 channel slope values (CSL10_85fm) were greater and 76 percent were lesser than computations done by Tortorelli (1997). Most of the overestimation of Tortorelli (1997) 10-85 channel slopes relative to StreamStats estimates seems to be the result of map-scale effects on measurements of the basin longest flow-path length. Tortorelli (1997), who measured $10-85$ channel slopes by using several map scales ranging from $1: 24,000$ to $1: 250,000$, tends to underestimate the basin longest flow-path length by about 20 percent as compared to StreamStats computations of longest flow-path length (L, fig. 11). Maps, by definition, are simplified representations of the earth's surface, and lose detail with decreasing map scale. Therefore, a stream represented at 1:250,000 scale is less detailed than the same stream represented at $1: 24,000$ scale. If the stream length was measured at both scales, the 1:250,000-scale stream would be shorter than the 1:24,000-scale stream. Also, more sinuous streams generally will be "shortened" to a greater degree than straighter streams in any map representation. Likewise, more sinuous segments of a given stream, mostly at downstream locations, are more simplified than straighter upstream segments and will receive greater "shortening" because of map-scale effects. Additional "shortening" could happen when using manual measurement techniques, as compared to automated methods at the same scale, because planimeters and map wheels are subject to some mechanical error.

Manual computations of the 10-85 change in elevation (Tortorelli, 1997) generally are greater than StreamStats automated computations of the 10-85 change in elevation. Because the placement of the 10-85 reference points is dependent on the measurement of stream length and because the measurement of stream length is dependent on map scale, the 10-85 change in elevation is dependent on map scale. The 10-85 reference points placed by using 1:24,000-scale maps will tend to be farther downstream than the corresponding 10-85 reference points placed by using 1:250,000-scale maps. The effect of this shift on the 10-85 change in elevation will vary with the sinuosity, length, and profile shape of each 
Table 3. Ranges of validity for basin characteristics (independent variables) used in computation of peak-flow frequency statistics in Oklahoma (modified from Tortorelli, 1997).

$\left[\mathrm{mi}^{2}\right.$, square miles; ft/mi, feet per mile; in., inches; \%, percent; NRCS, National Resources Conservation Service; FWR, floodwater retarding; 10-85 channel slope, slope between points at 10 percent and 85 percent of longest flow-path length upstream from the outlet]

\begin{tabular}{lcc}
\hline \multicolumn{1}{c}{ Independent variable } & Minimum & Maximum \\
\hline $\begin{array}{l}\text { Contributing area (CONTDA) or contributing drainage area that } \\
\text { is unregulated by NRCS FWR structures (DAUNREG) }\end{array}$ & $0.144 \mathrm{mi}^{2}$ & $2,510 \mathrm{mi}^{2}$ \\
$10-85$ channel slope (CSL10_85fm) & $1.89 \mathrm{ft} / \mathrm{mi}$ & $288^{*} \mathrm{ft} / \mathrm{mi}$ \\
Mean-annual precipitation at drainage-basin outlet (PRCOUT61) & $15.0 \mathrm{in}$. & $55.2 \mathrm{in}$. \\
Percentage of contributing drainage area regulated by NRCS & $0.0 \%$ & $86 \%$ \\
$\quad$ FWR structures (NRCSPCT) & & \\
\hline
\end{tabular}

\footnotetext{
* The station with the maximum 10-85 channel slope (Tortorelli, 1997) does not appear in appendix 1 because it was outside of the StreamStats processed area.
}

stream. However, the difference between 10-85 change in elevation measured at successive map scales will be greatest for streams in small basins with steep headwater reaches and gently sloping, highly sinuous downstream reaches (fig. 11).

Underestimation of longest flow-path length and overestimation of the 10-85 change in elevation result in overestimation of the 10-85 channel slope. The difference in slopes computed by manual (Tortorelli, 1997) and automated methods (StreamStats) should not cause a large difference in estimated peak-flow frequency statistics because the statistical significance of 10-85 channel slope as an independent variable in the regression is less than that of contributing drainage area or mean-annual precipitation at the drainage-basin outlet.

\section{Comparison of Peak-Flow Frequency Statistics Computed by Using Manual and Automated Computations of Basin Characteristics}

The differences in values for 10-85 channel slope and longest flow-path length have some effect on estimates of peak-flow frequency statistics, but these differences tend to be small because 10-85 channel slope (CSL10_85fm) is generally the least influential term in the peak-flow regression equation for most sites. On average, the StreamStats computed peak-flow frequency statistics tend to be slightly less than peak-flow frequency statistics computed by Tortorelli (1997) for 208 gages (appendix 2); about 60-67 percent of StreamStats peak-flow values for each statistic were less than peakflow values computed by Tortorelli (1997). However, a graphical comparison of PK5, PK50, and PK500 computed by using StreamStats basin characteristics as compared to Tortorelli (1997) basin characteristics shows that all peak-flow values computed at the 208 gages fall within the weighted standard error of estimate reported by Tortorelli (1997) (table 2; fig. 12) for each regression equation. In other words, the error because of differences in basin characteristic computation between Tortorelli (1997) and StreamStats is expected to be small compared to the error associated with the regionalized regression method for estimating peak-flow frequency statistics at ungaged sites.

Because the peak-flow regressions of Tortorelli (1997) were performed by using basin characteristic computation methods and streamflow data that were available in 1995, the peak-flow frequency statistics may not be optimized for use today (2010). The computational accuracy of methods for determining contributing drainage area and 10-85 channel slope have improved since the publication of Tortorelli (1997). Also, as more streamflow data become available each year, additional gages qualify for inclusion in statistical studies, and previously included gages have longer and more representative periods of record. Therefore, the Oklahoma peak-flow regressions should be periodically reevaluated and updated to ensure that the regressions remain accurate and relevant.

\section{Summary}

The USGS Streamflow Statistics (StreamStats) Program was created to make geographic information systems (GIS)based estimation of streamflow statistics easier, faster, and more consistent than previously used manual techniques. The StreamStats user interface is a map-based internet application that allows users to easily obtain streamflow statistics, basin characteristics, and other information for user-selected USGS data-collection stations and ungaged sites of interest. The application relies on the data collected at U.S. Geological Survey streamflow-gaging stations, computer aided computations of drainage-basin characteristics, and published regression equations for several geographic regions comprising the United States. The StreamStats application interface allows the user to (1) obtain information on features in selected map layers, (2) delineate drainage basins for ungaged sites, (3) download drainage-basin polygons to a shapefile, (4) compute selected basin characteristics for delineated drainage basins, 


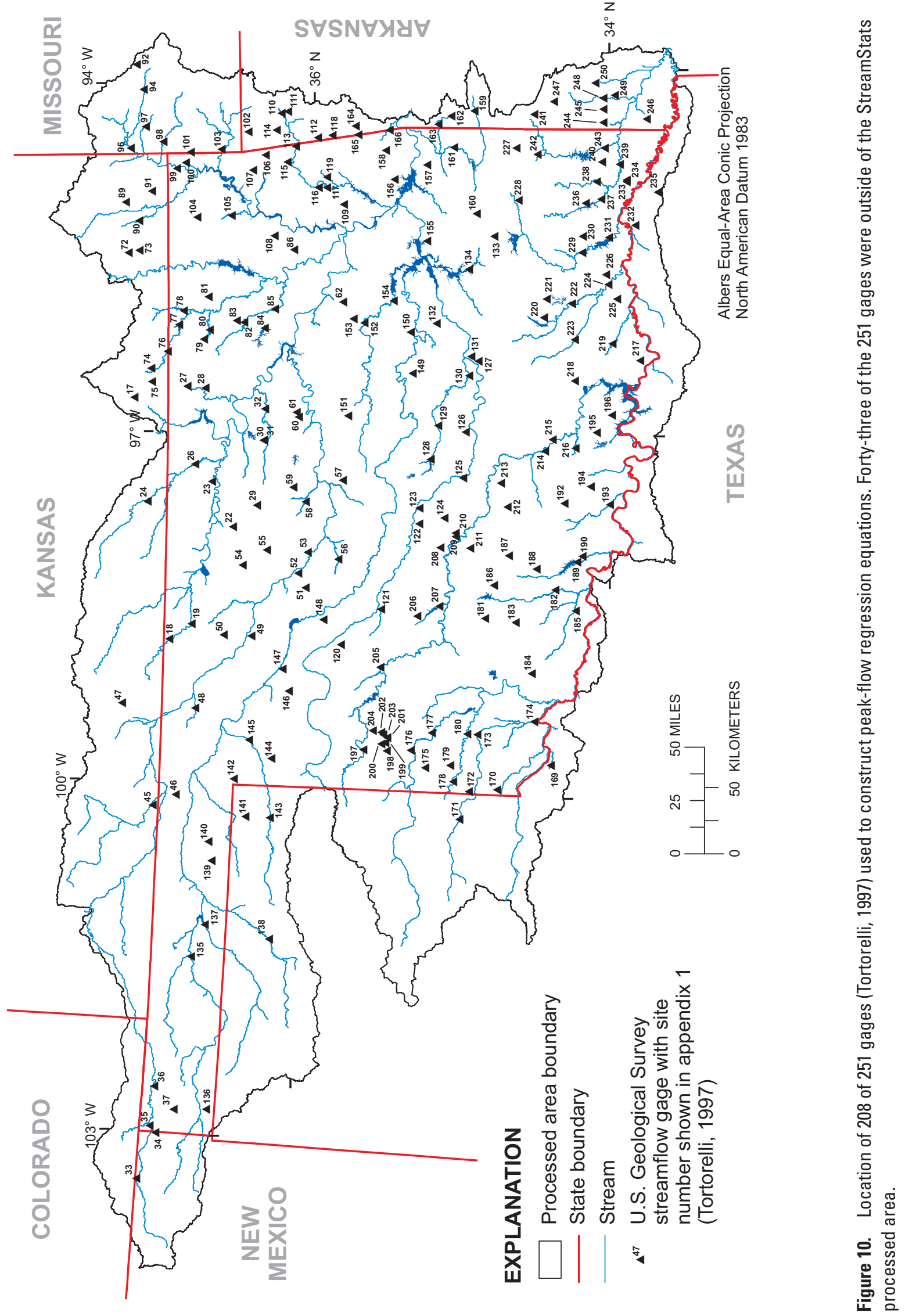



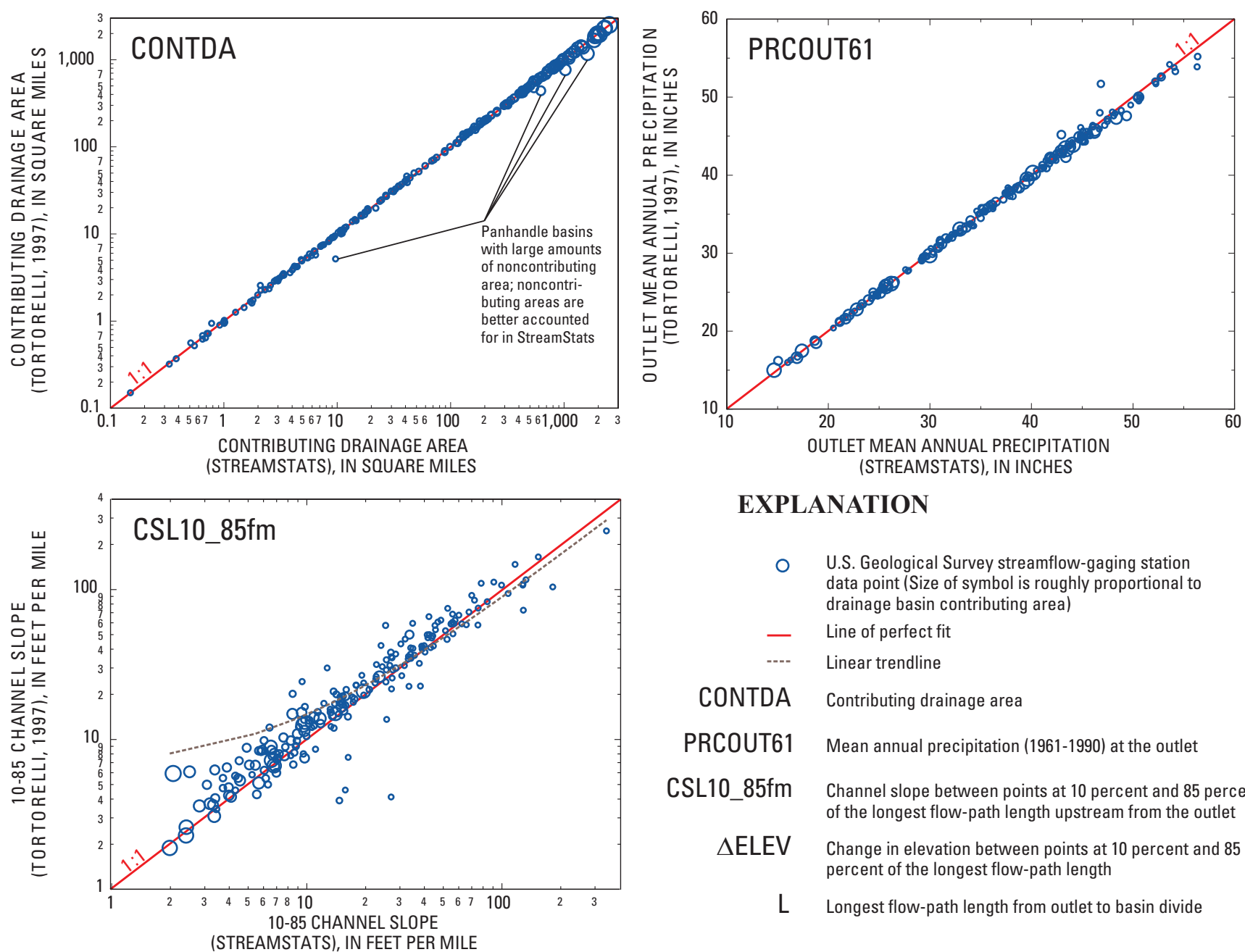

\section{EXPLANATION}

O U.S. Geological Survey streamflow-gaging station data point (Size of symbol is roughly proportional to drainage basin contributing area)

- Line of perfect fit

---- Linear trendline

CONTDA Contributing drainage area

PRCOUT61 Mean annual precipitation (1961-1990) at the outlet

CSL10_85fm Channel slope between points at 10 percent and 85 percent of the longest flow-path length upstream from the outlet

$\triangle E L E V \quad$ Change in elevation between points at 10 percent and 85 percent of the longest flow-path length

$\mathrm{L} \quad$ Longest flow-path length from outlet to basin divide
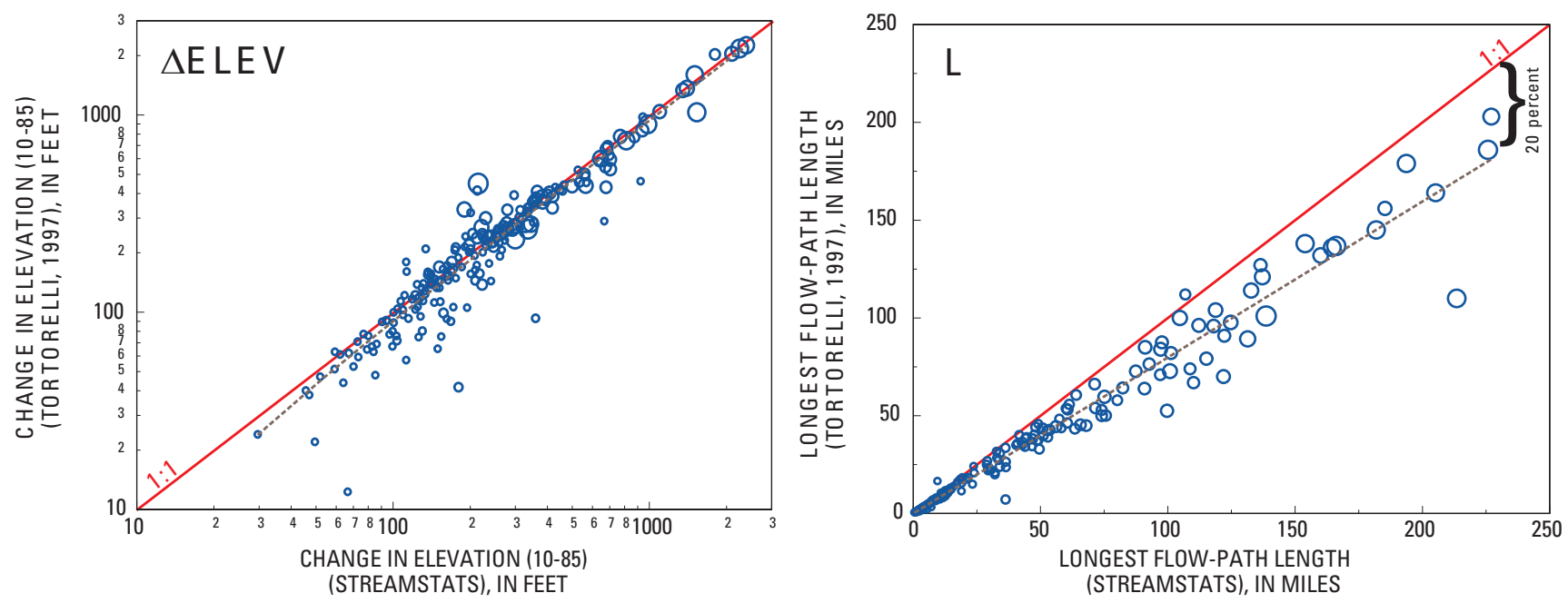

Figure 11. Comparison of basin characteristics from Tortorelli (1997), which were mostly computed by using manual techniques at a variety of map scales, and StreamStats, which were computed by using automated techniques on 1:24,000 scale data. 

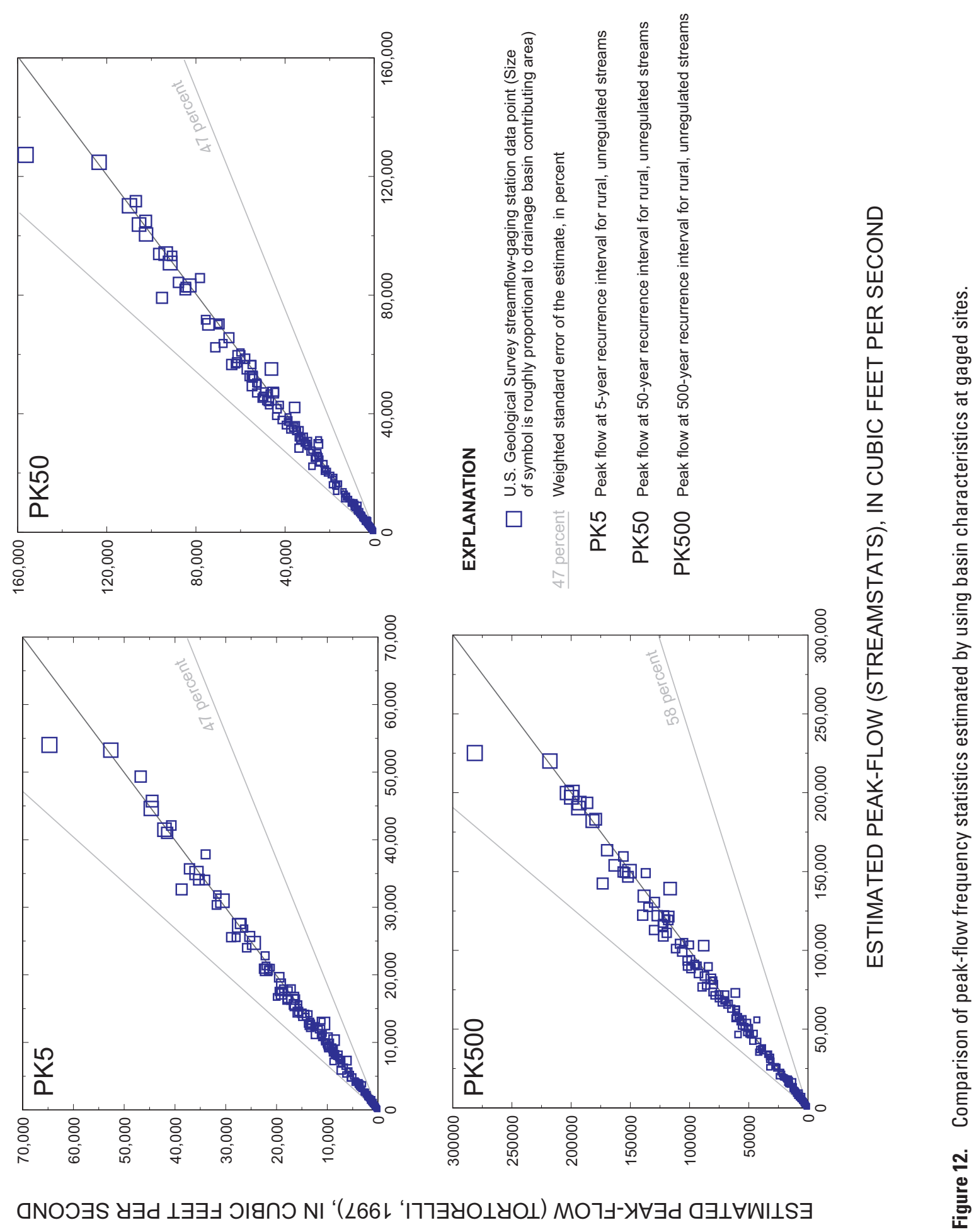
(5) estimate selected streamflow statistics for ungaged points on a stream, (6) print map views, (7) retrieve information for USGS streamflow-gaging stations, and (8) get help on using StreamStats.

StreamStats was designed for national application, with each state, territory, or group of states responsible for creating unique geospatial datasets and regression equations to compute selected streamflow statistics. With the cooperation of the Oklahoma Department of Transportation, StreamStats has been implemented for Oklahoma and is available at http://water.usgs.gov/osw/streamstats/.

The primary purpose of the Oklahoma StreamStats application is to provide estimates of drainage-basin characteristics and automatic estimation of streamflow statistics for user-selected ungaged sites on Oklahoma streams. The procedures created into the Oklahoma StreamStats application are optimized for rural, unregulated drainage basins in Oklahoma and with less than 2,510 square miles of contributing drainage area. The peak-flow estimation procedures also can be used in basins regulated by small floodwater retarding structures with the understanding that results may be less accurate in those settings. This report also describes a procedure for adjusting estimated peak-flow frequency statistics for urbanization effects.

The Oklahoma StreamStats application covers 69 processed hydrologic units and most of the state of Oklahoma. Basin characteristics available for computation include contributing drainage area, contributing drainage area that is unregulated by Natural Resources Conservation Service floodwater retarding structures, mean-annual precipitation at the drainage-basin outlet for the period 1961-1990, 10-85 channel slope (slope between points located at 10 percent and 85 percent of the longest flow-path length upstream from the outlet), and percent impervious area. In addition to these basin characteristics, 14 peak-flow (flood) frequency statistics are available for computation in the Oklahoma StreamStats application: the peak flow at 2-, 5-, 10-, 25-, 50-, 100-, and 500 -year recurrence intervals for rural, unregulated streams; and the peak flow at 2-, 5-, 10-, 25-, 50-, 100-, and 500-year recurrence intervals for rural streams that are regulated by Natural Resources Conservation Service floodwater retarding structures. Basin characteristics and streamflow statistics cannot be computed for locations in playa basins (mostly in the Oklahoma Panhandle) and along main stems of the largest river systems in the state, namely the Arkansas, Canadian, Cimarron, Neosho, Red, and Verdigris Rivers, because parts of the drainage areas extend outside of the processed hydrologic units.

Forty-three of the 251 gages used in a previous report to construct the 14 peak-flow regression equations were outside of the StreamStats processed hydrologic units. For the remaining 208 gages, basin characteristics computed by using StreamStats were compared to characteristics computed manually in a previous report. For contributing area, which is generally the most influential variable in the regression equations, the two estimates were nearly equal at most sites; 53 percent of the StreamStats computed contributing areas were greater and 47 percent were lesser than contributing areas computed in a previous report. Computations of mean-annual precipitation at the drainage-basin outlet in StreamStats were also in close agreement with computations in a previous report; 53 percent of the StreamStats computed precipitation values were greater and 47 percent were lesser than precipitation values computed for a previous report.

StreamStats automated computations of 10-85 channel slope tend to be slightly less than the manual computations done in a previous report; 24 percent of the StreamStats computed slope values were greater and 76 percent were less than slope values computed manually. The differences in values for 10-85 channel slope have some effect on estimates of peakflow frequency statistics, but these differences tend to be small because $10-85$ channel slope is generally the least influential term in the peak-flow regression equation for most sites. On average, the StreamStats computed peak-flow frequency statistics tend to be slightly less than peak-flow frequency statistics computed in a previous report for 208 gages; about 60-67 percent of StreamStats peak-flow values for each statistic were less than peak-flow values computed in a previous report. However, the error because of differences in basin characteristic computation between a previous report and StreamStats is expected to be small compared to the error associated with the regionalized regression method for estimating peak-flow frequency statistics at ungaged sites.

\section{References Cited}

Daly, Christopher, Neilson, R.P., and Phillips, D.L., 1994, A statistical-topographic model for mapping climatological precipitation over mountainous terrain: Journal of Applied Meteorology, v. 33 p. $140-158$.

Environmental Systems Research Institute, Inc., 2007, Hydro Data Model: Environmental Systems Research Institute, Inc., available online at http://support.esri.com/index. cfm? $f a=$ downloads.dataModels. filteredGateway\&dmid $=15$. (Accessed November 13, 2008.)

Hirsch, R.M., Helsel, D.R., Cohn, T.A., and Gilroy, E.J., 1993, Statistical treatment of hydrologic data, in Maidment, D.R., ed., Handbook of Hydrology: New York, McGraw-Hill, p. 17.1-17.55.

Koltun, G.F., Kula, S.P., and Puskas, B.M., 2006, A streamflow statistics (StreamStats) web application for Ohio: U.S. Geological Survey Scientific Investigations Report 2006-5312, $62 \mathrm{p}$.

Konrad, C.P., 2003, Effects of urban development on floods: U.S. Geological Survey Fact Sheet 076-03, 4 p. 
Leopold, L.B., 1968, Hydrology for urban land planning-A guidebook on the hydrologic effects of urban land use: U.S. Geological Survey Circular 554, 18 p.

Lewis, J.M. and Esralew, R.A., 2009, Statistical summaries of streamflow in and near Oklahoma through 2007: U.S. Geological Survey Scientific Investigations Report 2009-5135, $633 \mathrm{p}$.

Mandelbrot, B.B., 1983, The fractal geometry of nature: W. H. Freeman, New York, 468 p.

Multi-Resolution Land Characteristics Consortium, 2008, 2001 National Land Cover Database (NLCD), available online at http://www.epa.gov/mrlc/nlcd-2001.html. (Accessed August 21, 2008.)

Natural Resources Conservation Service, 2006, Watershed Boundary Dataset (WBD): U.S. Department of Agriculture, available online at http://www.ncgc.nrcs.usda.gov/products/ datasets/Watershed/. (Accessed November, 2006.)

Oklahoma Water Resources Board (OWRB), 2007, Oklahoma Water Atlas, available only online at http://www.owrb. ok.gov/news/publications/wa/wa.php.

PRISM Climate Group, 2008, Normal annual precipitation grid for the conterminous United States. available online at http://www.prism.oregonstate.edu/state_products/maps. phtml? id=US. (Accessed March 24, 2008.)

Rea, Alan, and Skinner, K.D., 2009, Estimated perennial streams of Idaho and related geospatial datasets: U.S. Geological Survey Data Series 412, 32 p.

Ries, K.G., III, Guthrie, J.G., Rea, A.H., Steeves, P.A., Stewart, D.W., 2008, StreamStats: A water resources web application: U.S. Geological Survey Fact Sheet 2008-3067, 6 p. (Available online at http://pubs.usgs.gov/fs/2008/3067/.)
Ries, K.G., III, Steeves, P.A., Coles, J.D., Rea, A.H., and Stewart, D.W., 2004, StreamStats-A U.S. Geological Survey web application for stream information: U.S. Geological Survey Fact Sheet 2004-3115, 4 p.

Sauer, V.B., 1974, An approach to estimating flood frequency for urban areas in Oklahoma: U.S. Geological Survey Water-Resources Investigations Report 23-74, 10 p.

Tasker, G.D., and Driver, N.E., 1988, Nationwide regression models for predicting urban runoff water quality at unmonitored sites: Water Resources Bulletin, v. 24, no. 5, p. 1,091-1,101.

Tortorelli, R.L., 1997, Techniques for estimating peak-streamflow frequency for unregulated streams and streams regulated by small floodwater retarding structures in Oklahoma: U.S. Geological Survey Water-Resources Investigations Report 97-4202, 39 p.

Tortorelli, R.L., 2002, Statistical summaries of streamflow in Oklahoma through 1999: U.S. Geological Survey WaterResources Investigations Report 02-4025, 510 p.

Tortorelli, R.L., and Bergman, D.L., 1985, Techniques for estimating flood peak discharges for unregulated streams and streams regulated by small floodwater retarding structures in Oklahoma: U.S. Geological Survey Water-Resources Investigations Report 84-4358, 85 p.

U.S. Geological Survey, 2006, National Elevation Dataset: U.S. Geological Survey, available only online at http://ned. usgs.gov/.

U.S. Geological Survey, 2008, National Hydrography Dataset: U.S. Geological Survey, available only online at $h t t p: / / n h d$. usgs.gov.

U.S. Geological Survey, 2009, National Streamflow Statistics Program, available only online at http://water.usgs.gov/osw/ programs/nss/index.html. (Accessed April 15, 2009.) 
Appendix 
Appendix 1. Basin characteristics computed by Tortorelli (1997) and StreamStats.

[Ark., Arkansas; Kans., Kansas; Mo., Missouri; N. Mex., New Mexico; Okla., Oklahoma; Tex., Texas; Trib., Tributary; S.H., State Highway; SWS, Subwatershed; NRCS FWR, Natural Resources Conservation Service floodwater retarding]

Tortorelli (1997)

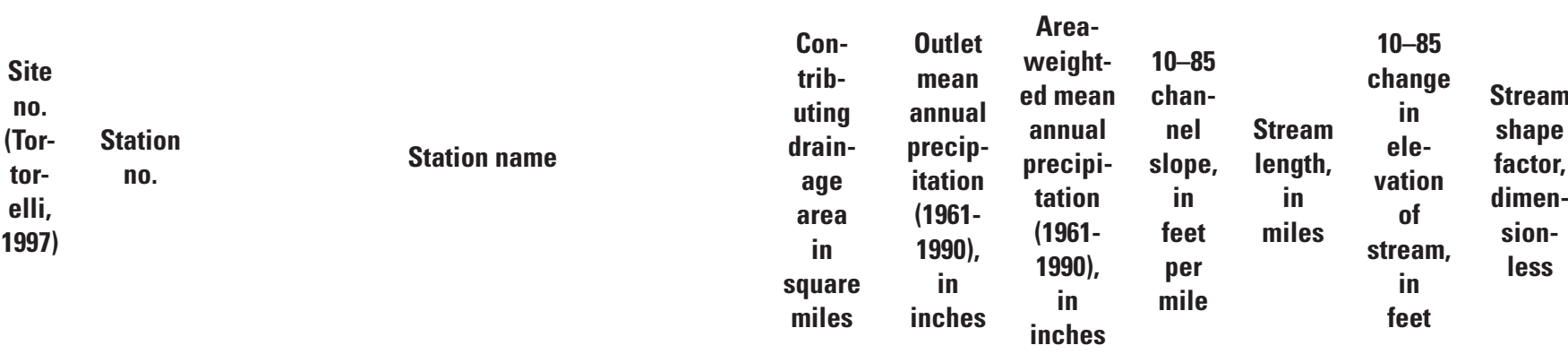

\begin{tabular}{|c|c|c|c|c|c|c|c|c|c|}
\hline 17 & 07148100 & Grouse Creek near Dexter, Kans. & 170 & 34.5 & 35.2 & 8.16 & 40.2 & 246.02 & 9.51 \\
\hline 18 & 07148350 & Salt Fork Arkansas River near Winchester, Okla. & 856 & 24.9 & 24.5 & 15.10 & 52.5 & 594.56 & 3.22 \\
\hline 19 & 07148400 & Salt Fork Arkansas River near Alva, Okla. & $1,009.00$ & 26.3 & 24.6 & 14.80 & 70 & 777.00 & 4.86 \\
\hline 22 & 07150580 & Sand Creek Trib. near Kremlin, Okla. & 7.21 & 31.7 & 31.6 & 19.30 & 6.9 & 99.88 & 6.6 \\
\hline 23 & 07150870 & Salt Fork Arkansas River Trib. near Eddy, Okla. & 2.35 & 32.9 & 32.9 & 19.80 & 2.7 & 40.10 & 3.1 \\
\hline 24 & 07151500 & Chikaskia River near Corbin, Kans. & 794 & 31.2 & 28.9 & 7.79 & 90.9 & 531.08 & 10.41 \\
\hline 26 & 07152000 & Chikaskia River near Blackwell, Okla. & $1,859.00$ & 33.1 & 30.0 & 7.25 & 136 & 739.50 & 9.95 \\
\hline 27 & 07152360 & Elm Creek near Foraker, Okla. & 18.2 & 35.7 & 36.1 & 17.50 & 9.4 & 123.38 & 4.85 \\
\hline 28 & 07152410 & Rock Creek near Shidler, Okla. & 9.13 & 35.9 & 35.9 & 35.80 & 5.4 & 144.99 & 3.19 \\
\hline 29 & 07152520 & Black Bear Creek Trib. near Garber, Okla. & 0.97 & 32.6 & 32.6 & 42.30 & 1.2 & 38.07 & 1.48 \\
\hline 30 & 07152842 & Subwatershed W-4 near Morrison, Okla. & 0.32 & 33.5 & 33.5 & 74.90 & 0.84 & 47.19 & 2.21 \\
\hline 31 & 07152846 & Subwatershed W-3 near Morrison, Okla. & 0.14 & 33.5 & 33.4 & 104.00 & 0.66 & 51.48 & 3.03 \\
\hline 32 & 07153000 & Black Bear Creek at Pawnee, Okla. & 576 & 35.8 & 33.7 & 4.05 & 71 & 215.66 & 8.75 \\
\hline 33 & 07153500 & Dry Cimarron River near Guy, N. Mex. & 545 & 16.2 & 17.1 & 50.00 & 54 & $2,025.00$ & 5.35 \\
\hline 34 & 07154400 & Carrizozo Creek near Kenton, Okla. & 111 & 16.7 & 16.8 & 38.00 & 34.2 & 974.70 & 10.54 \\
\hline 35 & 07154500 & Cimarron River near Kenton, Okla. & $1,038.00$ & 16.6 & 17.0 & 26.20 & 104 & $2,043.60$ & 10.42 \\
\hline 36 & 07155000 & $\begin{array}{l}\text { Cimarron River above Ute Creek near Boise } \\
\text { City, Okla. }\end{array}$ & $1,879.00$ & 15.0 & 17.1 & 21.00 & 138 & $2,173.50$ & 10.14 \\
\hline 37 & 07155100 & Cold Springs Creek near Wheeless, Okla. & 11 & 16.3 & 16.3 & 29.10 & 8.1 & 176.78 & 5.96 \\
\hline 45 & 07157500 & Crooked Creek near Nye, Kans. & 813 & 21.6 & 21.2 & 4.23 & 127 & 402.91 & 19.84 \\
\hline 46 & 07157550 & West Fork Creek near Knowles, Okla. & 4.22 & 21.7 & 21.7 & 59.20 & 3.9 & 173.16 & 3.6 \\
\hline 47 & 07157900 & Cavalry Creek at Coldwater, Kans. & 39 & 24.5 & 24.5 & 8.61 & 17.5 & 113.01 & 7.85 \\
\hline 48 & 07157960 & Buffalo Creek near Lovedale, Okla. & 408 & 25.0 & 25.2 & 12.76 & 38.7 & 370.36 & 3.67 \\
\hline 49 & 07158020 & Cimarron River Trib. near Lone Wolf, Okla. & 4.26 & 26.4 & 26.3 & 37.10 & 5.3 & 147.47 & 6.59 \\
\hline 50 & 07158080 & Sand Creek Trib. near Waynoka, Okla. & 1.61 & 25.9 & 25.9 & 62.40 & 2.2 & 102.96 & 3.01 \\
\hline 51 & 07158180 & Salt Creek Trib. near Okeene, Okla. & 8.23 & 29.2 & 29.1 & 30.00 & 8 & 180.00 & 7.78 \\
\hline
\end{tabular}


Appendix 1. Basin characteristics computed by Tortorelli (1997) and StreamStats.-Continued

[Ark., Arkansas; Kans., Kansas; Mo., Missouri; N. Mex., New Mexico; Okla., Oklahoma; Tex., Texas; Trib., Tributary; S.H., State Highway; SWS, Subwatershed; NRCS FWR, Natural Resources Conservation Service floodwater retarding]

\begin{tabular}{|c|c|c|c|c|c|c|c|c|c|}
\hline \multirow[b]{2}{*}{$\begin{array}{c}\text { Site } \\
\text { no. } \\
\text { (Tor- } \\
\text { tor- } \\
\text { elli, } \\
\text { 1997) }\end{array}$} & \multirow[b]{2}{*}{$\begin{array}{c}\text { Station } \\
\text { no. }\end{array}$} & \multicolumn{8}{|c|}{ StreamStats } \\
\hline & & $\begin{array}{l}\text { Contribut- } \\
\text { ing drain- } \\
\text { age area, } \\
\text { in square } \\
\text { miles } \\
\text { (CONTDA) }\end{array}$ & $\begin{array}{l}\text { Contrib- } \\
\text { uting drain- } \\
\text { age area } \\
\text { that } \\
\text { is ureg- } \\
\text { ulated } \\
\text { by NRCS } \\
\text { FWR } \\
\text { struc- } \\
\text { tures, in } \\
\text { square } \\
\text { miles } \\
\text { (DAUNREG) }\end{array}$ & $\begin{array}{l}\text { Contrib- } \\
\text { uting } \\
\text { drainage } \\
\text { area that is } \\
\text { regulated } \\
\text { by NRCS } \\
\text { FWR } \\
\text { structures, } \\
\text { in percent } \\
\text { (NRCSPCT) }\end{array}$ & $\begin{array}{c}\text { Outlet } \\
\text { mean } \\
\text { annual } \\
\text { precip- } \\
\text { itation } \\
\text { (1961-1990), } \\
\text { in inches } \\
\text { (PRCOUT61) }\end{array}$ & $\begin{array}{c}\text { 10-85 } \\
\text { channel } \\
\text { slope, } \\
\text { in } \\
\text { feet } \\
\text { per } \\
\text { mile } \\
\text { (CSL10_85fm) }\end{array}$ & $\begin{array}{l}\text { Length } \\
\text { of } \\
\text { longest } \\
\text { flow } \\
\text { path, } \\
\text { in } \\
\text { miles } \\
\text { (L) }\end{array}$ & $\begin{array}{c}\text { 10-85 } \\
\text { change } \\
\text { in } \\
\text { ele- } \\
\text { vation } \\
\text { of } \\
\text { longest } \\
\text { flow } \\
\text { path, } \\
\text { in feet } \\
\text { ( } \triangle \text { ELEV) }\end{array}$ & $\begin{array}{l}\text { Imper- } \\
\text { vious } \\
\text { area, } \\
\text { in } \\
\text { percent } \\
\text { (IM- } \\
\text { PNLCD01) }\end{array}$ \\
\hline 17 & 07148100 & 171.34 & 162.10 & 5.40 & 35.00 & 8.63 & 41.62 & 269.35 & 0.22 \\
\hline 18 & 07148350 & 827.23 & 827.23 & 0.00 & 25.13 & 9.40 & 99.66 & 702.85 & 0.10 \\
\hline 19 & 07148400 & 982.09 & 982.09 & 0.00 & 26.45 & 8.43 & 121.85 & 770.13 & 0.21 \\
\hline 22 & 07150580 & 7.13 & 7.13 & 0.00 & 31.76 & 14.76 & 9.08 & 100.49 & 0.39 \\
\hline 23 & 07150870 & 2.51 & 2.51 & 0.00 & 32.96 & 19.55 & 3.11 & 45.63 & 0.25 \\
\hline 24 & 07151500 & 812.58 & 812.58 & 0.00 & 31.17 & 7.67 & 122.22 & 703.24 & 0.32 \\
\hline 26 & 07152000 & $1,873.05$ & $1,873.05$ & 0.00 & 32.95 & 6.58 & 164.58 & 812.61 & 0.38 \\
\hline 27 & 07152360 & 18.34 & 18.34 & 0.00 & 36.19 & 14.65 & 12.13 & 133.33 & 0.17 \\
\hline 28 & 07152410 & 9.06 & 9.06 & 0.00 & 36.20 & 33.19 & 6.58 & 163.89 & 0.16 \\
\hline 29 & 07152520 & 1.02 & 1.02 & 0.00 & 32.51 & 24.01 & 2.62 & 47.09 & 1.49 \\
\hline 30 & 07152842 & 0.33 & 0.33 & 0.00 & 34.14 & 52.70 & 1.31 & 51.92 & 0.24 \\
\hline 31 & 07152846 & 0.08 & 0.08 & 0.00 & 34.32 & 182.11 & 0.43 & 59.09 & 0.45 \\
\hline 32 & 07153000 & 538.32 & 279.66 & 48.05 & 35.67 & 3.39 & 97.05 & 246.72 & 0.78 \\
\hline 33 & 07153500 & 527.58 & 527.58 & 0.00 & 15.05 & 33.60 & 71.49 & 1801.48 & 0.08 \\
\hline 34 & 07154400 & 112.28 & 112.28 & 0.00 & 16.95 & 26.94 & 46.66 & 942.91 & 0.06 \\
\hline 35 & 07154500 & $1,111.58$ & $1,111.58$ & 0.00 & 16.90 & 23.56 & 118.75 & 2097.87 & 0.09 \\
\hline 36 & 07155000 & $1,966.87$ & $1,966.69$ & 0.00 & 14.65 & 19.48 & 153.95 & 2249.54 & 0.08 \\
\hline 37 & 07155100 & 10.70 & 10.70 & 0.00 & 16.28 & 27.54 & 11.47 & 236.85 & 0.05 \\
\hline 45 & 07157500 & 821.97 & 821.97 & 0.00 & 21.71 & 3.98 & 136.41 & 407.59 & 0.18 \\
\hline 46 & 07157550 & 4.44 & 4.44 & 0.00 & 21.70 & 55.00 & 5.14 & 211.97 & 0.23 \\
\hline 47 & 07157900 & 41.54 & 41.54 & 0.00 & 24.85 & 11.08 & 18.38 & 152.70 & 0.29 \\
\hline 48 & 07157960 & 401.31 & 401.31 & 0.00 & 24.40 & 11.77 & 44.51 & 392.81 & 0.22 \\
\hline 49 & 07158020 & 4.20 & 4.20 & 0.00 & 26.11 & 28.55 & 6.82 & 145.95 & 0.53 \\
\hline 50 & 07158080 & 1.77 & 1.77 & 0.00 & 25.64 & 57.50 & 2.53 & 109.20 & 0.40 \\
\hline 51 & 07158180 & 8.37 & 8.37 & 0.00 & 29.13 & 12.71 & 11.80 & 112.51 & 0.56 \\
\hline
\end{tabular}


Appendix 1. Basin characteristics computed by Tortorelli (1997) and StreamStats._Continued

[Ark., Arkansas; Kans., Kansas; Mo., Missouri; N. Mex., New Mexico; Okla., Oklahoma; Tex., Texas; Trib., Tributary; S.H., State Highway; SWS, Subwatershed; NRCS FWR, Natural Resources Conservation Service floodwater retarding]

Tortorelli (1997)

\begin{tabular}{|c|c|c|c|c|c|c|c|c|c|}
\hline 52 & 07158400 & Salt Creek near Okeene, Okla. & 196 & 29.5 & 28.8 & 20.15 & 27.4 & 414.08 & 3.83 \\
\hline 53 & 07158500 & Preacher Creek near Dover, Okla. & 14.5 & 30.6 & 30.7 & 14.80 & 9.3 & 103.23 & 5.96 \\
\hline 54 & 07158550 & Turkey Creek Trib. near Goltry, Okla. & 5.08 & 29.0 & 28.7 & 19.50 & 5.3 & 77.51 & 5.53 \\
\hline 55 & 07159000 & Turkey Creek near Drummond, Okla. & 248 & 30.8 & 29.6 & 5.70 & 39 & 166.73 & 6.13 \\
\hline 56 & 07159200 & Kingfisher Creek near Kingfisher, Okla. & 157 & 29.9 & 29.0 & 12.00 & 23.7 & 213.30 & 3.58 \\
\hline 57 & 07159810 & Watershed W-IV near Guthrie, Okla. & 0.15 & 33.2 & 33.2 & 116.20 & 0.68 & 59.26 & 3.14 \\
\hline 58 & 07160500 & Skeleton Creek near Lovell, Okla. & 410 & 31.5 & 31.3 & 8.40 & 43.4 & 273.42 & 4.59 \\
\hline 59 & 07160550 & West Beaver Creek near Orlando, Okla. & 13.9 & 32.4 & 32.7 & 23.80 & 6.4 & 114.24 & 2.95 \\
\hline 60 & 07163000 & Council Creek near Stillwater, Okla. & 31 & 35.3 & 35.2 & 17.30 & 9 & 116.78 & 2.61 \\
\hline 61 & 07163020 & Corral Creek near Yale, Okla. & 2.89 & 35.4 & 35.4 & 53.90 & 2.4 & 97.02 & 1.99 \\
\hline 62 & 07165550 & Snake Creek near Bixby, Okla. & 50 & 39.8 & 40.0 & 24.30 & 11.5 & 209.59 & 2.65 \\
\hline 72 & 07170700 & Big Hill Creek near Cherryvale, Kans. & 37 & 41.9 & 41.0 & 9.10 & 24.2 & 165.17 & 15.83 \\
\hline 73 & 07170800 & Mud Creek near Mound Valley, Kans. & 4.22 & 42.6 & 42.6 & 25.67 & 3.48 & 67.00 & 2.87 \\
\hline 74 & 07171700 & Spring Branch near Cedar Vale, Kans. & 3.1 & 35.0 & 35.0 & 50.05 & 3.25 & 122.00 & 3.41 \\
\hline 75 & 07171800 & Cedar Creek Trib. near Hooser, Kans. & 0.56 & 35.4 & 35.4 & 165.00 & 1.53 & 189.34 & 4.18 \\
\hline 76 & 07172000 & Caney River near Elgin, Kans. & 445 & 38.0 & 35.9 & 7.39 & 60.6 & 335.88 & 8.25 \\
\hline 77 & 07173000 & Caney River near Hulah, Okla. & 736 & 35.6 & 36.4 & 6.73 & 72.7 & 366.95 & 7.18 \\
\hline 78 & 07174200 & $\begin{array}{l}\text { Little Caney River below Cotton Creek } \\
\text { near Copan, Okla. }\end{array}$ & 502 & 36.6 & 37.7 & 8.80 & 50.1 & 330.66 & 5 \\
\hline 79 & 07174570 & Dry Hollow near Pawhuska, Okla. & 1.67 & 37.6 & 37.6 & 83.00 & 1.8 & 112.05 & 1.94 \\
\hline 80 & 07174600 & Sand Creek at Okesa, Okla. & 139 & 37.7 & 37.6 & 13.50 & 37 & 374.63 & 9.85 \\
\hline 81 & 07174720 & $\begin{array}{l}\text { Hogshooter Creek Trib. near Bartles- } \\
\text { ville, Okla. }\end{array}$ & 0.94 & 38.4 & 38.4 & 58.20 & 1.1 & 48.02 & 1.29 \\
\hline 82 & 07176500 & Bird Creek at Avant, Okla. & 364 & 38.3 & 38.1 & 6.22 & 55.8 & 260.31 & 8.55 \\
\hline 83 & 07176800 & Candy Creek near Wolco, Okla. & 30.6 & 38.5 & 38.9 & 17.60 & 10.98 & 144.94 & 3.94 \\
\hline 84 & 07177000 & Hominy Creek near Skiatook, Okla. & 340 & 38.0 & 37.2 & 7.20 & 46.3 & 250.02 & 6.3 \\
\hline 85 & 07177500 & Bird Creek near Sperry, Okla. & 905 & 38.9 & 37.8 & 4.14 & 85 & 263.93 & 7.98 \\
\hline
\end{tabular}


Appendix 1. Basin characteristics computed by Tortorelli (1997) and StreamStats.-Continued

[Ark., Arkansas; Kans., Kansas; Mo., Missouri; N. Mex., New Mexico; Okla., Oklahoma; Tex., Texas; Trib., Tributary; S.H., State Highway; SWS, Subwatershed; NRCS FWR, Natural Resources Conservation Service floodwater retarding]

\begin{tabular}{|c|c|c|c|c|c|c|c|c|c|}
\hline \multirow[b]{2}{*}{$\begin{array}{l}\text { Site } \\
\text { no. } \\
\text { (Tor- } \\
\text { tor- } \\
\text { elli, } \\
1997 \text { ) }\end{array}$} & \multirow[b]{2}{*}{$\begin{array}{c}\text { Station } \\
\text { no. }\end{array}$} & \multicolumn{8}{|c|}{ StreamStats } \\
\hline & & $\begin{array}{l}\text { Contribut- } \\
\text { ing drain- } \\
\text { age area, } \\
\text { in square } \\
\text { miles } \\
\text { (CONTDA) }\end{array}$ & $\begin{array}{l}\text { Contrib- } \\
\text { uting drain- } \\
\text { age area } \\
\text { that } \\
\text { is ureg- } \\
\text { ulated } \\
\text { by NRCS } \\
\text { FWR } \\
\text { struc- } \\
\text { tures, in } \\
\text { square } \\
\text { miles } \\
\text { (DAUNREG) }\end{array}$ & $\begin{array}{l}\text { Contrib- } \\
\text { uting } \\
\text { drainage } \\
\text { area that is } \\
\text { regulated } \\
\text { by NRCS } \\
\text { FWR } \\
\text { structures, } \\
\text { in percent } \\
\text { (NRCSPCT) }\end{array}$ & $\begin{array}{c}\text { Outlet } \\
\text { mean } \\
\text { annual } \\
\text { precip- } \\
\text { itation } \\
\text { (1961-1990), } \\
\text { in inches } \\
\text { (PRCOUT61) }\end{array}$ & $\begin{array}{c}\text { 10-85 } \\
\text { channel } \\
\text { slope, } \\
\text { in } \\
\text { feet } \\
\text { per } \\
\text { mile } \\
\text { (CSL10_85fm) }\end{array}$ & $\begin{array}{l}\text { Length } \\
\text { of } \\
\text { longest } \\
\text { flow } \\
\text { path, } \\
\text { in } \\
\text { miles } \\
\text { (L) }\end{array}$ & $\begin{array}{c}\text { 10-85 } \\
\text { change } \\
\text { in } \\
\text { ele- } \\
\text { vation } \\
\text { of } \\
\text { longest } \\
\text { flow } \\
\text { path, } \\
\text { in feet } \\
\text { ( } \triangle E L E V \text { ) }\end{array}$ & $\begin{array}{l}\text { Imper- } \\
\text { vious } \\
\text { area, } \\
\text { in } \\
\text { percent } \\
\text { (IM- } \\
\text { PNLCD01) }\end{array}$ \\
\hline 52 & 07158400 & 181.49 & 181.49 & 0.00 & 29.30 & 8.45 & 33.62 & 213.14 & 0.64 \\
\hline 53 & 07158500 & 14.33 & 14.33 & 0.00 & 30.09 & 14.47 & 11.25 & 122.08 & 0.50 \\
\hline 54 & 07158550 & 4.82 & 4.82 & 0.00 & 29.22 & 15.13 & 6.75 & 76.67 & 0.57 \\
\hline 55 & 07159000 & 254.76 & 252.26 & 0.98 & 30.86 & 4.31 & 52.90 & 170.85 & 0.59 \\
\hline 56 & 07159200 & 165.14 & 165.14 & 0.00 & 30.24 & 6.44 & 36.39 & 175.65 & 0.35 \\
\hline 57 & 07159810 & 0.15 & 0.15 & 0.00 & 32.98 & 132.65 & 0.74 & 73.16 & 0.05 \\
\hline 58 & 07160500 & 412.05 & 412.05 & 0.00 & 31.02 & 5.67 & 63.49 & 270.05 & 2.36 \\
\hline 59 & 07160550 & 13.58 & 13.58 & 0.00 & 32.16 & 19.55 & 8.93 & 130.96 & 0.08 \\
\hline 60 & 07163000 & 30.03 & 30.03 & 0.00 & 35.17 & 13.88 & 11.42 & 118.86 & 0.39 \\
\hline 61 & 07163020 & 3.01 & 3.01 & 0.00 & 35.33 & 45.65 & 3.19 & 109.19 & 0.21 \\
\hline 62 & 07165550 & 47.69 & 47.69 & 0.00 & 39.58 & 9.45 & 18.93 & 134.14 & 0.15 \\
\hline 72 & 07170700 & 36.84 & 36.84 & 0.00 & 42.42 & 8.80 & 23.74 & 156.70 & 0.58 \\
\hline 73 & 07170800 & 4.40 & 4.40 & 0.00 & 43.16 & 27.39 & 4.02 & 82.63 & 0.44 \\
\hline 74 & 07171700 & 3.08 & 3.08 & 0.00 & 34.78 & 42.41 & 3.48 & 110.78 & 0.49 \\
\hline 75 & 07171800 & 0.51 & 0.51 & 0.00 & 34.61 & 153.63 & 1.56 & 179.66 & 0.03 \\
\hline 76 & 07172000 & 428.50 & 245.51 & 42.70 & 37.85 & 7.02 & 64.02 & 336.99 & 0.37 \\
\hline 77 & 07173000 & 710.78 & 527.79 & 25.74 & 35.30 & 5.45 & 87.39 & 357.01 & 0.29 \\
\hline 78 & 07174200 & 503.37 & 276.73 & 45.02 & 36.49 & 4.92 & 75.67 & 279.24 & 0.51 \\
\hline 79 & 07174570 & 1.72 & 1.72 & 0.00 & 37.43 & 84.08 & 2.30 & 144.76 & 0.32 \\
\hline 80 & 07174600 & 137.83 & 137.83 & 0.00 & 37.44 & 9.67 & 48.74 & 353.64 & 0.17 \\
\hline 81 & 07174720 & 0.78 & 0.78 & 0.00 & 37.68 & 65.71 & 1.73 & 85.20 & 0.65 \\
\hline 82 & 07176500 & 368.55 & 368.55 & 0.00 & 38.66 & 6.05 & 61.29 & 278.27 & 0.50 \\
\hline 83 & 07176800 & 31.35 & 31.35 & 0.00 & 38.45 & 15.15 & 13.42 & 152.51 & 0.15 \\
\hline 84 & 07177000 & 340.11 & 340.11 & 0.00 & 38.04 & 4.50 & 60.54 & 204.41 & 0.31 \\
\hline 85 & 07177500 & 906.98 & 906.98 & 0.00 & 39.31 & 4.09 & 91.08 & 279.34 & 0.53 \\
\hline
\end{tabular}


Appendix 1. Basin characteristics computed by Tortorelli (1997) and StreamStats.-Continued

[Ark., Arkansas; Kans., Kansas; Mo., Missouri; N. Mex., New Mexico; Okla., Oklahoma; Tex., Texas; Trib., Tributary; S.H., State Highway; SWS, Subwatershed; NRCS FWR, Natural Resources Conservation Service floodwater retarding]

Tortorelli (1997)

\begin{tabular}{|c|c|c|}
\hline $\begin{array}{c}\text { Site } \\
\text { no. } \\
\text { (Tor- } \\
\text { tor- } \\
\text { elli, } \\
\text { 1997) }\end{array}$ & $\begin{array}{c}\text { Station } \\
\text { no. }\end{array}$ & Station name \\
\hline
\end{tabular}

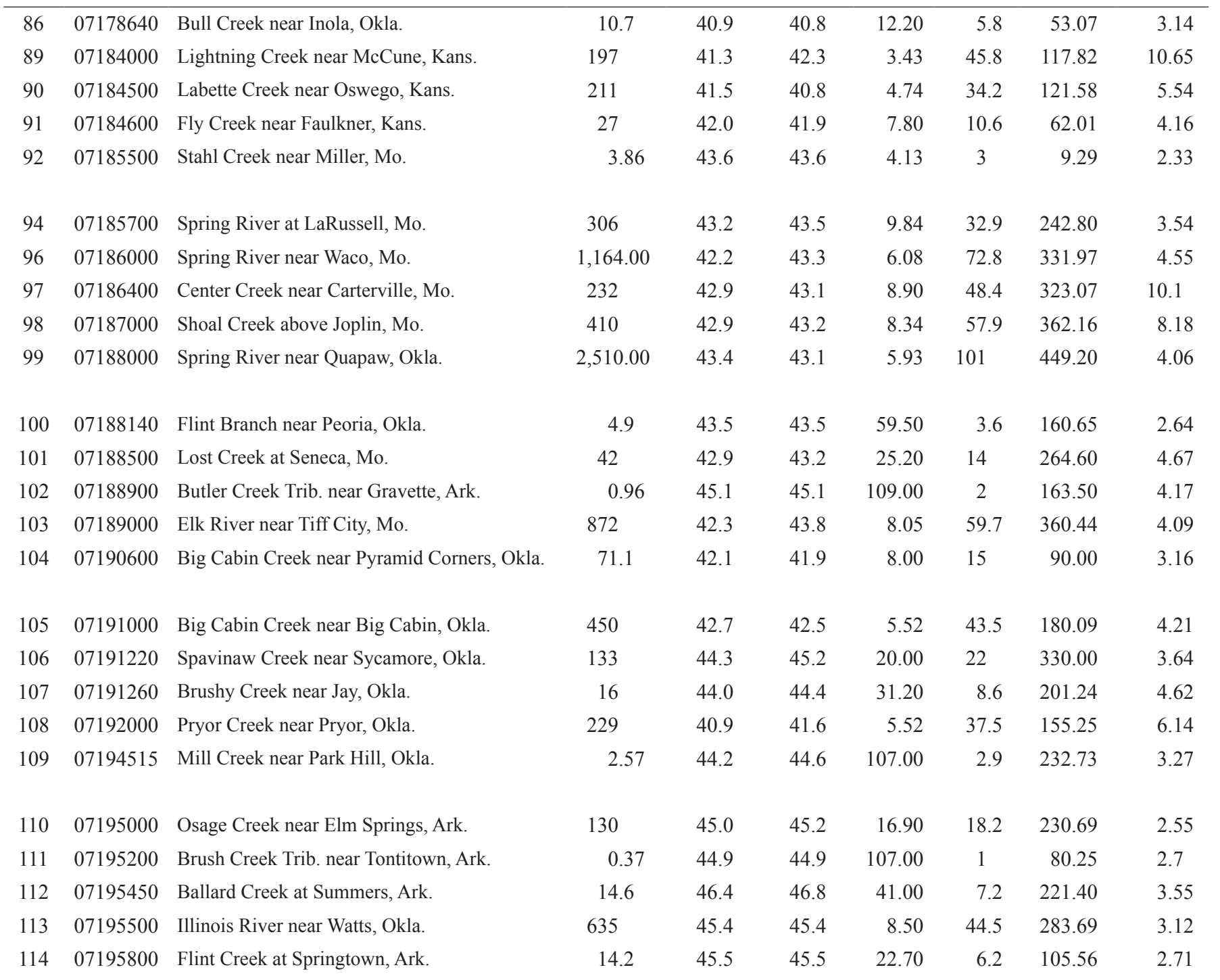


Appendix 1. Basin characteristics computed by Tortorelli (1997) and StreamStats.-Continued

[Ark., Arkansas; Kans., Kansas; Mo., Missouri; N. Mex., New Mexico; Okla., Oklahoma; Tex., Texas; Trib., Tributary; S.H., State Highway; SWS, Subwatershed; NRCS FWR, Natural Resources Conservation Service floodwater retarding]

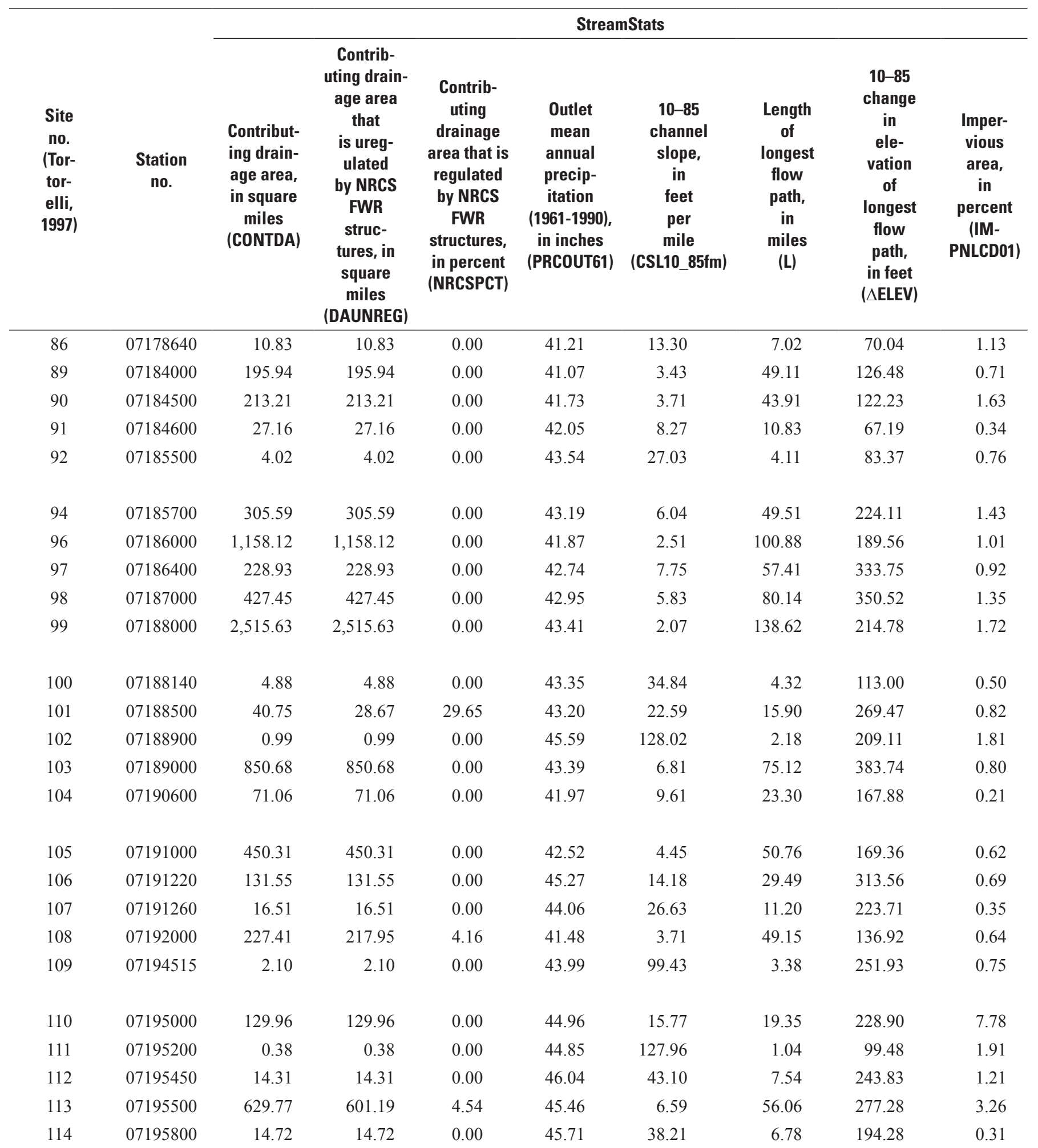


Appendix 1. Basin characteristics computed by Tortorelli (1997) and StreamStats._Continued

[Ark., Arkansas; Kans., Kansas; Mo., Missouri; N. Mex., New Mexico; Okla., Oklahoma; Tex., Texas; Trib., Tributary; S.H., State Highway; SWS, Subwatershed; NRCS FWR, Natural Resources Conservation Service floodwater retarding]

Tortorelli (1997)

Site
no.
(Tor-
tor-
elli, notion
1997)

Station name

1997)

\begin{tabular}{|c|c|c|c|c|c|c|c|c|c|}
\hline 115 & 07196000 & Flint Creek near Kansas, Okla. & 110 & 45.1 & 45.4 & 19.40 & 23.4 & 340.47 & 4.98 \\
\hline 116 & 07196380 & Steely Hollow near Tahlequah, Okla. & 3.59 & 45.2 & 45.2 & 110.00 & 2.6 & 214.50 & 1.88 \\
\hline 117 & 07196500 & Illinois River near Tahlequah, Okla. & 959 & 44.9 & 45.4 & 5.33 & 96.2 & 384.56 & 9.65 \\
\hline 118 & 07196900 & Baron Fork at Dutch Mills, Ark. & 46 & 46.9 & 47.6 & 40.20 & 11.6 & 349.74 & 2.93 \\
\hline 119 & 07197000 & Baron Fork at Eldon, Okla. & 307 & 44.9 & 46.2 & 13.40 & 38.2 & 383.91 & 4.75 \\
\hline 120 & 07228290 & Rough Creek near Thomas, Okla. & 10.4 & 27.8 & 27.6 & 41.00 & 6.3 & 193.73 & 3.82 \\
\hline 121 & 07228450 & Deer Creek Trib. near Hydro, Okla. & 2.31 & 29.0 & 29.0 & 59.00 & 1.7 & 75.23 & 1.25 \\
\hline 122 & 07228930 & Worley Creek near Tuttle, Okla. & 11.2 & 33.7 & 33.7 & 19.20 & 6.3 & 90.72 & 3.54 \\
\hline 123 & 07228960 & Canadian River Trib. near Newcastle, Okla. & 3.32 & 33.8 & 33.8 & 49.10 & 3.8 & 139.94 & 4.35 \\
\hline 124 & 07229220 & Walnut Creek near Blanchard, Okla. & 1.26 & 33.8 & 33.8 & 70.80 & 1.3 & 69.03 & 1.34 \\
\hline 125 & 07229300 & Walnut Creek near Purcell, Okla. & 202 & 36.9 & 34.6 & 7.72 & 7.2 & 41.69 & 0.26 \\
\hline 126 & 07229420 & Julian Creek Trib. near Asher, Okla. & 2.28 & 37.6 & 37.6 & 35.00 & 2.4 & 63.00 & 2.53 \\
\hline 127 & 07229430 & Arbeca Creek near Allen, Okla. & 2.26 & 39.6 & 39.6 & 26.60 & 2.2 & 43.89 & 2.14 \\
\hline 128 & 07230000 & $\begin{array}{l}\text { Little River below Lake Thunderbird near } \\
\text { Norman, Okla. }\end{array}$ & 257 & 36.2 & 35.1 & 5.50 & 24 & 99.00 & 2.24 \\
\hline 129 & 07230500 & Little River near Tecumseh, Okla. & 456 & 37.8 & 35.9 & 4.30 & 42.8 & 138.03 & 4.02 \\
\hline 130 & 07231000 & Little River near Sasakwa, Okla. & 865 & 38.4 & 36.9 & 3.66 & 95.9 & 263.25 & 10.63 \\
\hline 131 & 07231320 & Leader Creek Trib. near Atwood, Okla. & 0.72 & 39.9 & 39.9 & 75.20 & 1.15 & 64.86 & 1.84 \\
\hline 132 & 07231560 & Middle Creek near Carson, Okla. & 7.4 & 40.6 & 40.6 & 21.70 & 4.6 & 74.86 & 2.86 \\
\hline 133 & 07231950 & Pine Creek near Higgins, Okla. & 9.99 & 48.1 & 48.1 & 62.40 & 5.1 & 238.68 & 2.6 \\
\hline 134 & 07232000 & Gaines Creek near Krebs, Okla. & 588 & 43.6 & 45.4 & 4.98 & 45.4 & 169.57 & 3.51 \\
\hline 135 & 07232500 & Beaver River near Guymon, Okla. & 1,175 & 17.5 & 16.6 & 14.80 & 203 & $2,253.30$ & 35.07 \\
\hline 136 & 07232650 & Aqua Frio Creek near Felt, Okla. & 31 & 16.0 & 15.6 & 23.00 & 15.4 & 265.65 & 7.65 \\
\hline 137 & 07233000 & Coldwater Creek near Hardesty, Okla. & 767 & 18.5 & 17.1 & 11.40 & 156 & $1,333.80$ & 31.73 \\
\hline 138 & 07233500 & Palo Duro Creek near Spearman, Tex. & 440 & 18.8 & 17.6 & 9.83 & 74 & 545.57 & 12.45 \\
\hline 139 & 07234050 & North Fork Clear Creek near Balko, Okla. & 4.22 & 20.4 & 20.4 & 29.10 & 4.06 & 88.61 & 3.91 \\
\hline
\end{tabular}


Appendix 1. Basin characteristics computed by Tortorelli (1997) and StreamStats.-Continued

[Ark., Arkansas; Kans., Kansas; Mo., Missouri; N. Mex., New Mexico; Okla., Oklahoma; Tex., Texas; Trib., Tributary; S.H., State Highway; SWS, Subwatershed; NRCS FWR, Natural Resources Conservation Service floodwater retarding]

\begin{tabular}{|c|c|c|c|c|c|c|c|c|c|}
\hline \multirow[b]{2}{*}{$\begin{array}{l}\text { Site } \\
\text { no. } \\
\text { (Tor- } \\
\text { tor- } \\
\text { elli, } \\
\text { 1997) }\end{array}$} & \multirow[b]{2}{*}{$\begin{array}{c}\text { Station } \\
\text { no. }\end{array}$} & \multicolumn{8}{|c|}{ StreamStats } \\
\hline & & $\begin{array}{l}\text { Contribut- } \\
\text { ing drain- } \\
\text { age area, } \\
\text { in square } \\
\text { miles } \\
\text { (CONTDA) }\end{array}$ & $\begin{array}{l}\text { Contrib- } \\
\text { uting drain- } \\
\text { age area } \\
\text { that } \\
\text { is ureg- } \\
\text { ulated } \\
\text { by NRCS } \\
\text { FWR } \\
\text { struc- } \\
\text { tures, in } \\
\text { square } \\
\text { miles } \\
\text { (DAUNREG) }\end{array}$ & $\begin{array}{c}\text { Contrib- } \\
\text { uting } \\
\text { drainage } \\
\text { area that is } \\
\text { regulated } \\
\text { by NRCS } \\
\text { FWR } \\
\text { structures, } \\
\text { in percent } \\
\text { (NRCSPCT) }\end{array}$ & $\begin{array}{c}\text { Outlet } \\
\text { mean } \\
\text { annual } \\
\text { precip- } \\
\text { itation } \\
\text { (1961-1990), } \\
\text { in inches } \\
\text { (PRCOUT61) }\end{array}$ & $\begin{array}{c}\text { 10-85 } \\
\text { channel } \\
\text { slope, } \\
\text { in } \\
\text { feet } \\
\text { per } \\
\text { mile } \\
\text { (CSL10_85fm) }\end{array}$ & $\begin{array}{l}\text { Length } \\
\text { of } \\
\text { longest } \\
\text { flow } \\
\text { path, } \\
\text { in } \\
\text { miles } \\
\text { (L) }\end{array}$ & $\begin{array}{c}\text { 10-85 } \\
\text { change } \\
\text { in } \\
\text { ele- } \\
\text { vation } \\
\text { of } \\
\text { longest } \\
\text { flow } \\
\text { path, } \\
\text { in feet } \\
\text { ( } \triangle \text { ELEV) }\end{array}$ & $\begin{array}{l}\text { Imper- } \\
\text { vious } \\
\text { area, } \\
\text { in } \\
\text { percent } \\
\text { (IM- } \\
\text { PNLCD01) }\end{array}$ \\
\hline 115 & 07196000 & 115.59 & 115.59 & 0.00 & 45.78 & 15.33 & 29.36 & 337.60 & 2.08 \\
\hline 116 & 07196380 & 3.84 & 3.84 & 0.00 & 44.83 & 78.25 & 3.25 & 190.51 & 0.28 \\
\hline 117 & 07196500 & 950.25 & 921.68 & 3.01 & 44.72 & 4.54 & 112.15 & 381.96 & 2.50 \\
\hline 118 & 07196900 & 41.09 & 41.09 & 0.00 & 47.47 & 39.02 & 12.36 & 361.75 & 0.37 \\
\hline 119 & 07197000 & 311.58 & 307.95 & 1.16 & 44.93 & 10.28 & 46.86 & 361.20 & 0.36 \\
\hline 120 & 07228290 & 10.19 & 10.19 & 0.00 & 27.91 & 39.26 & 7.07 & 208.14 & 0.17 \\
\hline 121 & 07228450 & 2.32 & 2.32 & 0.00 & 29.16 & 62.25 & 3.30 & 154.13 & 1.17 \\
\hline 122 & 07228930 & 11.22 & 11.22 & 0.00 & 33.89 & 17.11 & 7.38 & 94.65 & 0.86 \\
\hline 123 & 07228960 & 3.27 & 3.27 & 0.00 & 33.99 & 44.15 & 4.21 & 139.35 & 2.23 \\
\hline 124 & 07229220 & 1.27 & 1.27 & 0.00 & 34.03 & 67.78 & 1.70 & 86.26 & 0.09 \\
\hline 125 & 07229300 & 202.13 & 202.13 & 0.00 & 37.23 & 6.61 & 36.29 & 179.92 & 0.93 \\
\hline 126 & 07229420 & 2.30 & 2.30 & 0.00 & 37.69 & 27.35 & 2.89 & 59.32 & 0.22 \\
\hline 127 & 07229430 & 2.12 & 2.12 & 0.00 & 39.52 & 30.67 & 2.78 & 63.98 & 0.37 \\
\hline 128 & 07230000 & 257.09 & 257.09 & 0.00 & 36.23 & 6.15 & 34.08 & 157.26 & 3.89 \\
\hline 129 & 07230500 & 462.50 & 462.50 & 0.00 & 37.72 & 5.54 & 53.54 & 222.53 & 2.26 \\
\hline 130 & 07231000 & 888.35 & 834.30 & 6.08 & 38.80 & 3.30 & 117.99 & 292.42 & 1.31 \\
\hline 131 & 07231320 & 0.73 & 0.73 & 0.00 & 40.29 & 75.47 & 1.40 & 79.09 & 0.47 \\
\hline 132 & 07231560 & 7.34 & 7.34 & 0.00 & 40.48 & 27.16 & 6.17 & 125.75 & 0.12 \\
\hline 133 & 07231950 & 10.83 & 10.83 & 0.00 & 47.97 & 48.66 & 6.24 & 227.77 & 0.08 \\
\hline 134 & 07232000 & 585.08 & 529.04 & 9.58 & 43.91 & 3.07 & 65.72 & 151.51 & 0.41 \\
\hline 135 & 07232500 & $1,611.74$ & $1,611.74$ & 0.00 & 17.39 & 14.03 & 227.04 & 2389.03 & 0.24 \\
\hline 136 & 07232650 & 31.52 & 31.52 & 0.00 & 16.00 & 17.89 & 19.08 & 255.92 & 0.37 \\
\hline 137 & 07233000 & $1,028.81$ & $1,028.81$ & 0.00 & 18.79 & 9.71 & 185.31 & 1349.31 & 0.32 \\
\hline 138 & 07233500 & 624.68 & 624.68 & 0.00 & 18.66 & 8.27 & 108.73 & 674.44 & 0.49 \\
\hline 139 & 07234050 & 4.30 & 4.30 & 0.00 & 20.50 & 25.53 & 5.25 & 100.56 & 0.14 \\
\hline
\end{tabular}


Appendix 1. Basin characteristics computed by Tortorelli (1997) and StreamStats.-Continued

[Ark., Arkansas; Kans., Kansas; Mo., Missouri; N. Mex., New Mexico; Okla., Oklahoma; Tex., Texas; Trib., Tributary; S.H., State Highway; SWS, Subwatershed; NRCS FWR, Natural Resources Conservation Service floodwater retarding]

Tortorelli (1997)

\begin{tabular}{|c|c|c|}
\hline $\begin{array}{c}\text { Site } \\
\text { no. } \\
\text { (Tor- } \\
\text { tor- } \\
\text { elli, } \\
\text { 1997) }\end{array}$ & $\begin{array}{c}\text { Station } \\
\text { no. }\end{array}$ & Station name \\
\hline
\end{tabular}

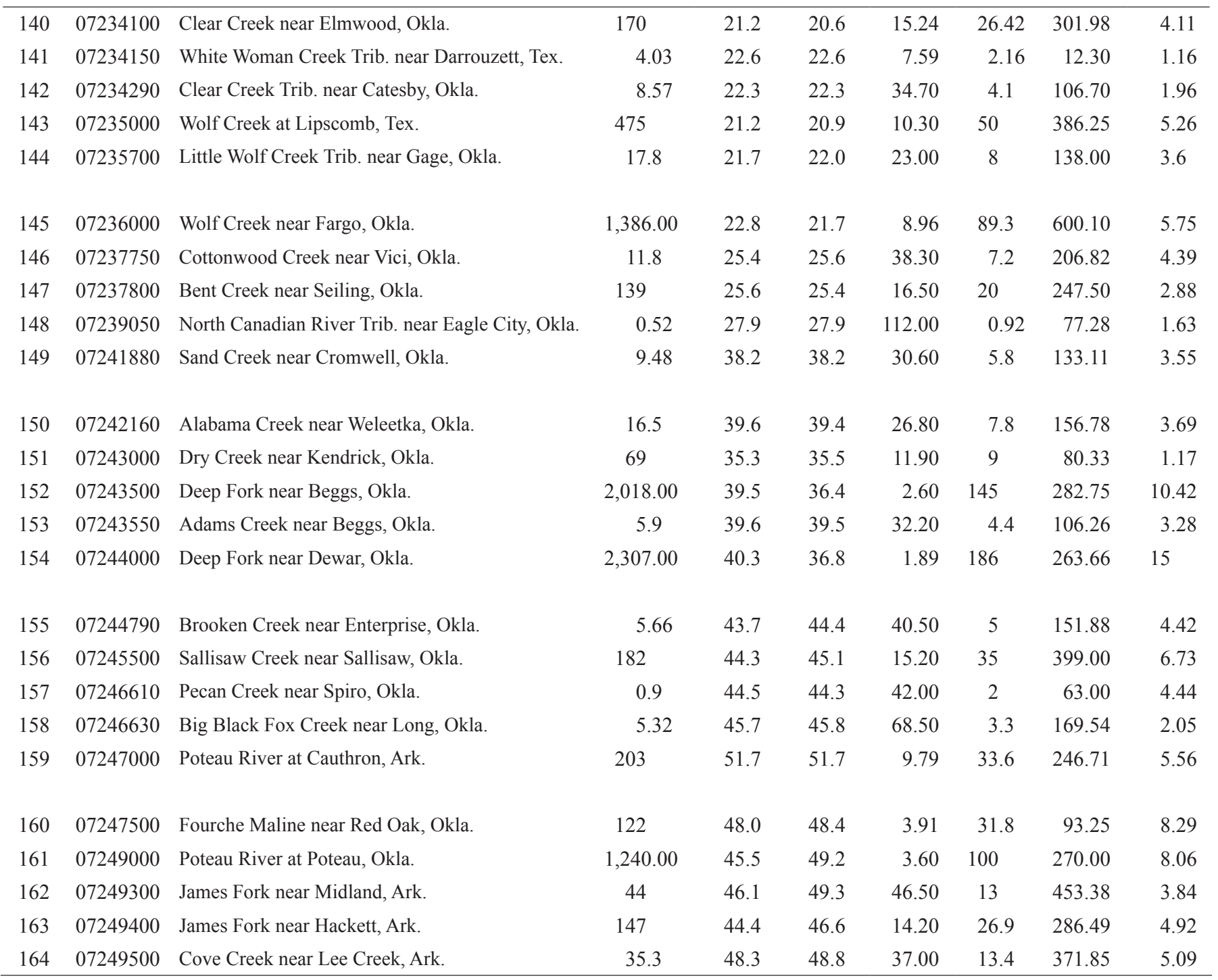


Appendix 1. Basin characteristics computed by Tortorelli (1997) and StreamStats.-Continued

[Ark., Arkansas; Kans., Kansas; Mo., Missouri; N. Mex., New Mexico; Okla., Oklahoma; Tex., Texas; Trib., Tributary; S.H., State Highway; SWS, Subwatershed; NRCS FWR, Natural Resources Conservation Service floodwater retarding]

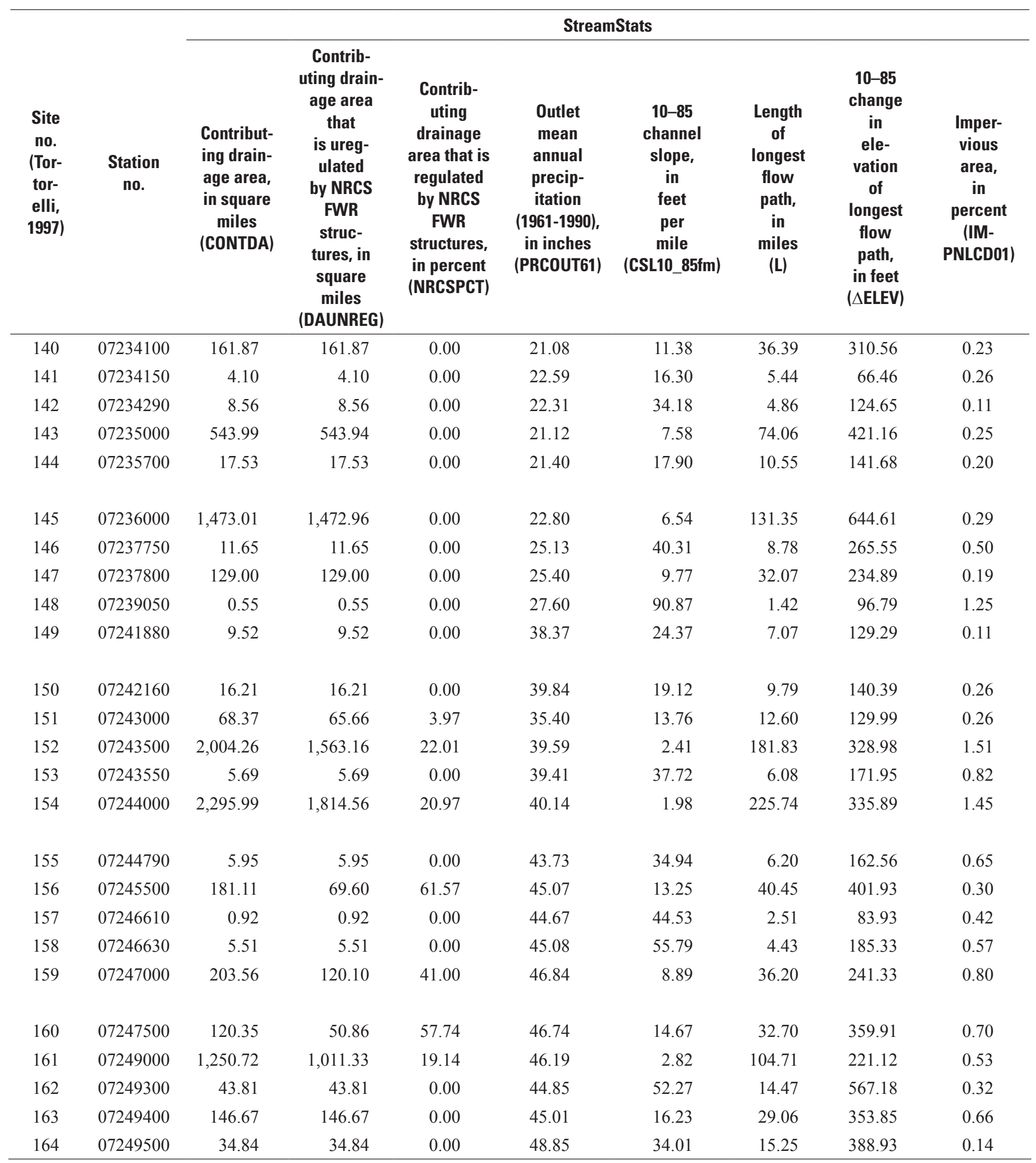


Appendix 1. Basin characteristics computed by Tortorelli (1997) and StreamStats.-Continued

[Ark., Arkansas; Kans., Kansas; Mo., Missouri; N. Mex., New Mexico; Okla., Oklahoma; Tex., Texas; Trib., Tributary; S.H., State Highway; SWS, Subwatershed; NRCS FWR, Natural Resources Conservation Service floodwater retarding]

Tortorelli (1997)

Site

no.

(Tor- Station

tor- no.

elli,

1997)

\section{Station name}

$\begin{array}{cc} & \\ \text { Con- } & \text { Outlet } \\ \text { trib- } & \text { mean } \\ \text { uting } & \text { annual } \\ \text { drain- } & \text { precip- } \\ \text { age } & \text { itation } \\ \text { area } & (1961- \\ \text { in } & 1990), \\ \text { square } & \text { in } \\ \text { miles } & \text { inches }\end{array}$

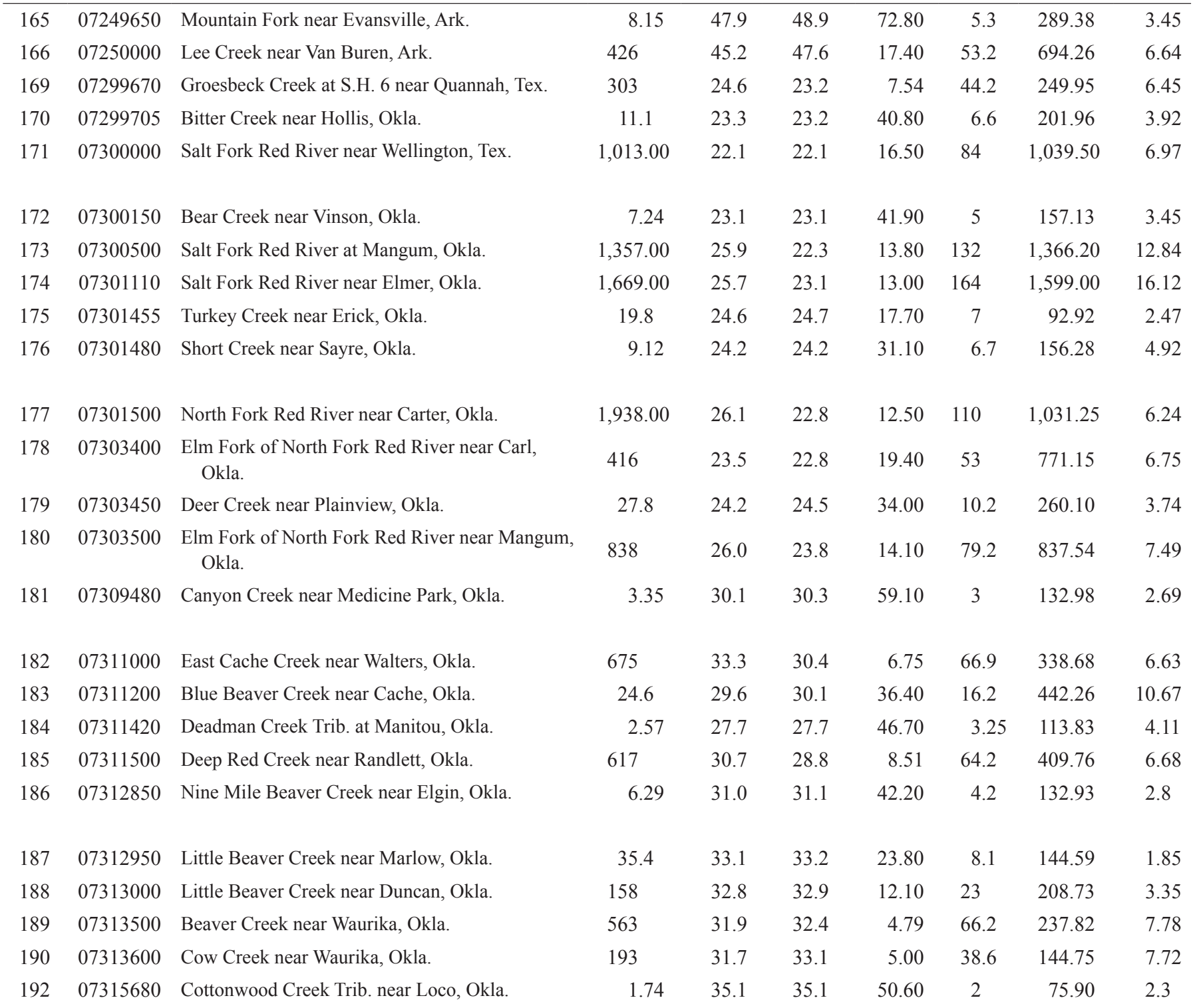


Appendix 1. Basin characteristics computed by Tortorelli (1997) and StreamStats.-Continued

[Ark., Arkansas; Kans., Kansas; Mo., Missouri; N. Mex., New Mexico; Okla., Oklahoma; Tex., Texas; Trib., Tributary; S.H., State Highway; SWS, Subwatershed; NRCS FWR, Natural Resources Conservation Service floodwater retarding]

\begin{tabular}{|c|c|c|c|c|c|c|c|c|c|}
\hline \multirow[b]{2}{*}{$\begin{array}{c}\text { Site } \\
\text { no. } \\
\text { (Tor- } \\
\text { tor- } \\
\text { elli, } \\
\text { 1997) }\end{array}$} & \multirow[b]{2}{*}{$\begin{array}{c}\text { Station } \\
\text { no. }\end{array}$} & \multicolumn{8}{|c|}{ StreamStats } \\
\hline & & $\begin{array}{l}\text { Contribut- } \\
\text { ing drain- } \\
\text { age area, } \\
\text { in square } \\
\text { miles } \\
\text { (CONTDA) }\end{array}$ & $\begin{array}{l}\text { Contrib- } \\
\text { uting drain- } \\
\text { age area } \\
\text { that } \\
\text { is ureg- } \\
\text { ulated } \\
\text { by NRCS } \\
\text { FWR } \\
\text { struc- } \\
\text { tures, in } \\
\text { square } \\
\text { miles } \\
\text { (DAUNREG) }\end{array}$ & $\begin{array}{c}\text { Contrib- } \\
\text { uting } \\
\text { drainage } \\
\text { area that is } \\
\text { regulated } \\
\text { by NRCS } \\
\text { FWR } \\
\text { structures, } \\
\text { in percent } \\
\text { (NRCSPCT) }\end{array}$ & $\begin{array}{c}\text { Outlet } \\
\text { mean } \\
\text { annual } \\
\text { precip- } \\
\text { itation } \\
\text { (1961-1990), } \\
\text { in inches } \\
\text { (PRCOUT61) }\end{array}$ & $\begin{array}{c}\text { 10-85 } \\
\text { channel } \\
\text { slope, } \\
\text { in } \\
\text { feet } \\
\text { per } \\
\text { mile } \\
\text { (CSL10_85fm) }\end{array}$ & $\begin{array}{l}\text { Length } \\
\text { of } \\
\text { longest } \\
\text { flow } \\
\text { path, } \\
\text { in } \\
\text { miles } \\
\text { (L) }\end{array}$ & $\begin{array}{c}\text { 10-85 } \\
\text { change } \\
\text { in } \\
\text { ele- } \\
\text { vation } \\
\text { of } \\
\text { longest } \\
\text { flow } \\
\text { path, } \\
\text { in feet } \\
\text { ( } \triangle \text { ELEV) }\end{array}$ & $\begin{array}{l}\text { Imper- } \\
\text { vious } \\
\text { area, } \\
\text { in } \\
\text { percent } \\
\text { (IM- } \\
\text { PNLCD01) }\end{array}$ \\
\hline 165 & 07249650 & 8.40 & 8.40 & 0.00 & 48.23 & 128.70 & 6.91 & 666.79 & 0.15 \\
\hline 166 & 07250000 & 437.97 & 437.97 & 0.00 & 42.94 & 15.12 & 60.64 & 687.45 & 0.18 \\
\hline 169 & 07299670 & 320.00 & 320.00 & 0.00 & 24.44 & 7.10 & 48.08 & 256.15 & 0.50 \\
\hline 170 & 07299705 & 11.48 & 11.48 & 0.00 & 23.28 & 34.08 & 7.74 & 197.80 & 0.09 \\
\hline 171 & 07300000 & 979.49 & 979.43 & 0.00 & 22.00 & 15.06 & 97.15 & 1097.15 & 0.13 \\
\hline 172 & 07300150 & 7.18 & 7.18 & 0.00 & 23.06 & 38.79 & 5.59 & 162.58 & 0.04 \\
\hline 173 & 07300500 & $1,319.45$ & $1,319.39$ & 0.00 & 25.68 & 11.66 & 160.00 & 1399.73 & 0.16 \\
\hline 174 & 07301110 & $1,847.90$ & $1,757.42$ & 4.89 & 25.66 & 9.77 & 205.21 & 1504.22 & 0.25 \\
\hline 175 & 07301455 & 21.87 & 21.87 & 0.00 & 24.66 & 17.30 & 8.85 & 114.75 & 0.76 \\
\hline 176 & 07301480 & 9.28 & 9.28 & 0.00 & 24.27 & 31.62 & 8.46 & 200.59 & 0.15 \\
\hline 177 & 07301500 & $2,072.51$ & $1,834.19$ & 11.50 & 26.19 & 9.57 & 213.45 & 1531.73 & 0.26 \\
\hline 178 & 07303400 & 437.96 & 437.96 & 0.00 & 23.34 & 15.76 & 74.04 & 875.21 & 0.30 \\
\hline 179 & 07303450 & 26.78 & 26.78 & 0.00 & 24.23 & 25.58 & 13.26 & 254.29 & 0.06 \\
\hline 180 & 07303500 & 846.33 & 846.33 & 0.00 & 25.72 & 10.87 & 115.17 & 939.18 & 0.21 \\
\hline 181 & 07309480 & 3.39 & 3.39 & 0.00 & 30.31 & 56.74 & 3.56 & 151.58 & 0.19 \\
\hline 182 & 07311000 & 693.50 & 693.50 & 0.00 & 33.57 & 5.07 & 110.08 & 418.56 & 2.40 \\
\hline 183 & 07311200 & 24.67 & 24.67 & 0.00 & 29.41 & 35.58 & 17.37 & 463.50 & 0.35 \\
\hline 184 & 07311420 & 2.58 & 2.58 & 0.00 & 27.82 & 31.93 & 4.47 & 107.04 & 0.81 \\
\hline 185 & 07311500 & 604.08 & 485.49 & 19.63 & 30.79 & 5.92 & 82.29 & 365.15 & 0.36 \\
\hline 186 & 07312850 & 6.36 & 6.36 & 0.00 & 31.09 & 39.94 & 4.93 & 147.77 & 2.17 \\
\hline 187 & 07312950 & 34.86 & 34.86 & 0.00 & 33.39 & 22.37 & 8.96 & 150.40 & 0.29 \\
\hline 188 & 07313000 & 156.58 & 156.58 & 0.00 & 32.99 & 9.11 & 29.34 & 200.51 & 0.64 \\
\hline 189 & 07313500 & 564.36 & 564.36 & 0.00 & 31.58 & 3.98 & 71.25 & 212.64 & 0.38 \\
\hline 190 & 07313600 & 192.66 & 144.17 & 25.17 & 31.00 & 6.32 & 44.09 & 209.11 & 2.21 \\
\hline 192 & 07315680 & 1.81 & 1.81 & 0.00 & 34.90 & 56.06 & 2.45 & 103.06 & 0.02 \\
\hline
\end{tabular}


Appendix 1. Basin characteristics computed by Tortorelli (1997) and StreamStats.-Continued

[Ark., Arkansas; Kans., Kansas; Mo., Missouri; N. Mex., New Mexico; Okla., Oklahoma; Tex., Texas; Trib., Tributary; S.H., State Highway; SWS, Subwatershed; NRCS FWR, Natural Resources Conservation Service floodwater retarding]

\section{Tortorelli (1997)}

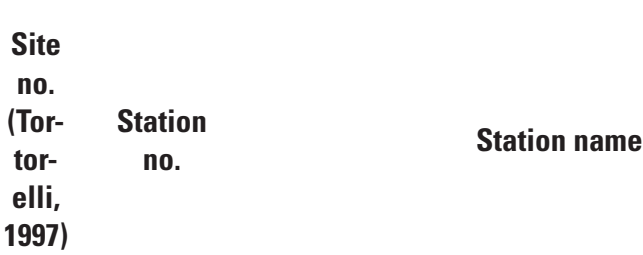

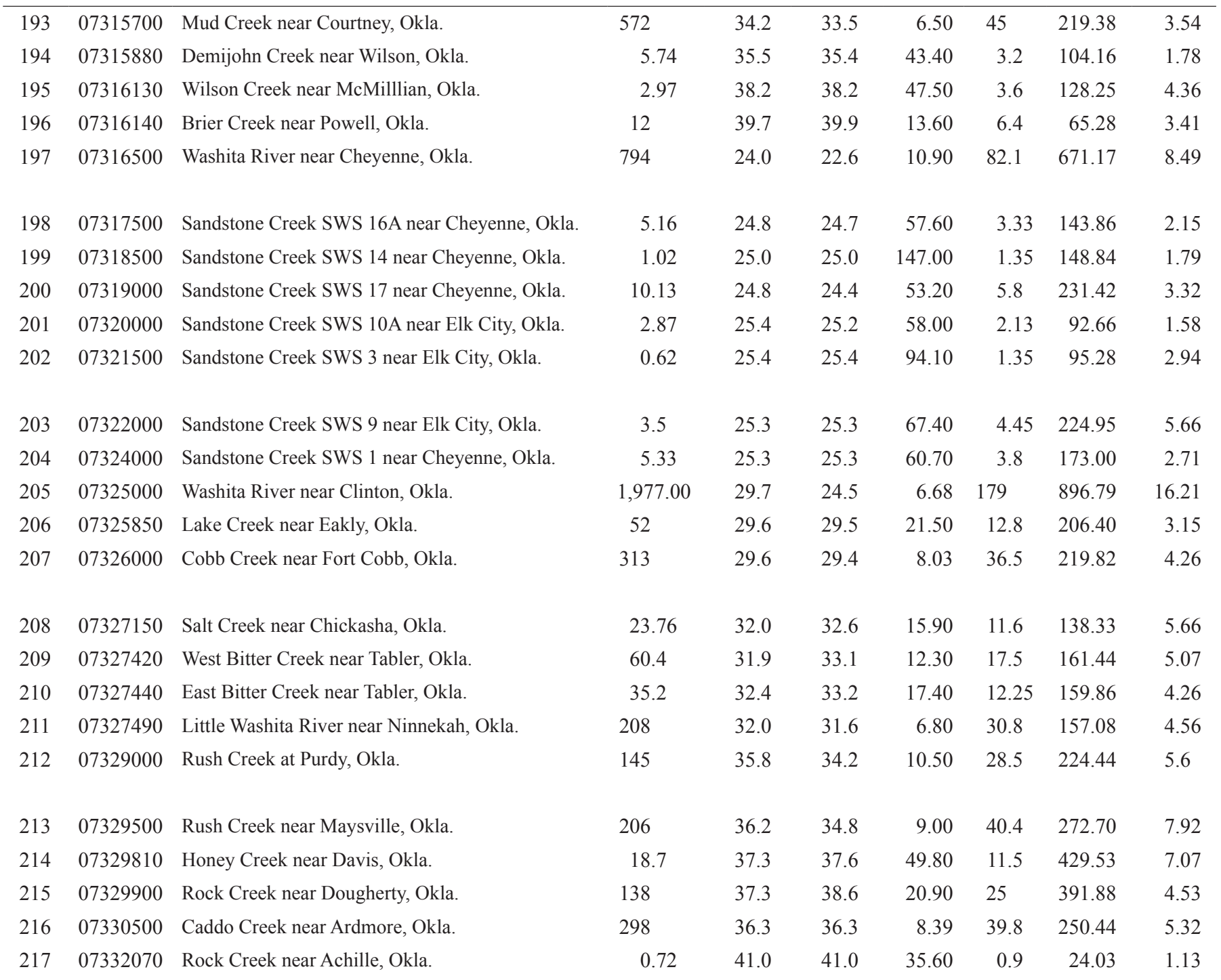


Appendix 1. Basin characteristics computed by Tortorelli (1997) and StreamStats.-Continued

[Ark., Arkansas; Kans., Kansas; Mo., Missouri; N. Mex., New Mexico; Okla., Oklahoma; Tex., Texas; Trib., Tributary; S.H., State Highway; SWS, Subwatershed; NRCS FWR, Natural Resources Conservation Service floodwater retarding]

\begin{tabular}{|c|c|c|c|c|c|c|c|c|c|}
\hline \multirow[b]{2}{*}{$\begin{array}{l}\text { Site } \\
\text { no. } \\
\text { (Tor- } \\
\text { tor- } \\
\text { elli, } \\
\text { 1997) }\end{array}$} & \multirow[b]{2}{*}{$\begin{array}{c}\text { Station } \\
\text { no. }\end{array}$} & \multicolumn{8}{|c|}{ StreamStats } \\
\hline & & $\begin{array}{l}\text { Contribut- } \\
\text { ing drain- } \\
\text { age area, } \\
\text { in square } \\
\text { miles } \\
\text { (CONTDA) }\end{array}$ & $\begin{array}{l}\text { Contrib- } \\
\text { uting drain- } \\
\text { age area } \\
\text { that } \\
\text { is ureg- } \\
\text { ulated } \\
\text { by NRCS } \\
\text { FWR } \\
\text { struc- } \\
\text { tures, in } \\
\text { square } \\
\text { miles } \\
\text { (DAUNREG) }\end{array}$ & $\begin{array}{l}\text { Contrib- } \\
\text { uting } \\
\text { drainage } \\
\text { area that is } \\
\text { regulated } \\
\text { by NRCS } \\
\text { FWR } \\
\text { structures, } \\
\text { in percent } \\
\text { (NRCSPCT) }\end{array}$ & $\begin{array}{c}\text { Outlet } \\
\text { mean } \\
\text { annual } \\
\text { precip- } \\
\text { itation } \\
\text { (1961-1990), } \\
\text { in inches } \\
\text { (PRCOUT61) }\end{array}$ & $\begin{array}{c}\text { 10-85 } \\
\text { channel } \\
\text { slope, } \\
\text { in } \\
\text { feet } \\
\text { per } \\
\text { mile } \\
\text { (CSL10_85fm) }\end{array}$ & $\begin{array}{l}\text { Length } \\
\text { of } \\
\text { longest } \\
\text { flow } \\
\text { path, } \\
\text { in } \\
\text { miles } \\
\text { (L) }\end{array}$ & $\begin{array}{c}10-85 \\
\text { change } \\
\text { in } \\
\text { ele- } \\
\text { vation } \\
\text { of } \\
\text { longest } \\
\text { flow } \\
\text { path, } \\
\text { in feet } \\
\text { ( } \triangle \text { ELEV) }\end{array}$ & $\begin{array}{l}\text { Imper- } \\
\text { vious } \\
\text { area, } \\
\text { in } \\
\text { percent } \\
\text { (IM- } \\
\text { PNLCD01) }\end{array}$ \\
\hline 193 & 07315700 & 574.41 & 574.41 & 0.00 & 34.00 & 3.89 & 67.94 & 198.22 & 0.16 \\
\hline 194 & 07315880 & 6.44 & 6.44 & 0.00 & 35.39 & 30.34 & 4.57 & 103.91 & 0.39 \\
\hline 195 & 07316130 & 2.95 & 2.95 & 0.00 & 37.88 & 43.67 & 4.08 & 133.52 & 0.22 \\
\hline 196 & 07316140 & 11.99 & 11.99 & 0.00 & 39.81 & 25.65 & 7.75 & 149.18 & 0.26 \\
\hline 197 & 07316500 & 762.59 & 246.53 & 67.67 & 23.95 & 8.96 & 101.27 & 680.73 & 0.17 \\
\hline 198 & 07317500 & 9.68 & 0.00 & 99.99 & 24.67 & 45.39 & 7.08 & 241.04 & 0.15 \\
\hline 199 & 07318500 & 1.01 & 0.07 & 92.58 & 24.95 & 116.64 & 2.01 & 175.58 & 0.04 \\
\hline 200 & 07319000 & 11.11 & 0.02 & 99.83 & 24.84 & 51.32 & 7.10 & 273.20 & 0.25 \\
\hline 201 & 07320000 & 2.79 & 0.00 & 99.90 & 25.25 & 75.30 & 2.87 & 161.92 & 0.05 \\
\hline 202 & 07321500 & 0.65 & 0.00 & 99.45 & 25.44 & 107.51 & 1.59 & 127.92 & 0.02 \\
\hline 203 & 07322000 & 3.36 & 0.00 & 99.86 & 25.44 & 60.09 & 5.78 & 260.35 & 0.02 \\
\hline 204 & 07324000 & 5.39 & 0.06 & 98.80 & 25.56 & 46.93 & 4.61 & 162.27 & 0.04 \\
\hline 205 & 07325000 & $1,948.58$ & 836.48 & 57.07 & 29.99 & 6.79 & 193.68 & 986.94 & 0.20 \\
\hline 206 & 07325850 & 52.46 & 52.46 & 0.00 & 29.72 & 15.90 & 14.61 & 174.23 & 0.18 \\
\hline 207 & 07326000 & 310.72 & 262.43 & 15.54 & 29.50 & 7.23 & 42.81 & 232.22 & 0.25 \\
\hline 208 & 07327150 & 23.79 & 23.79 & 0.00 & 31.92 & 13.17 & 12.57 & 124.18 & 0.50 \\
\hline 209 & 07327420 & 59.70 & 41.85 & 29.90 & 31.87 & 10.89 & 20.69 & 168.98 & 0.52 \\
\hline 210 & 07327440 & 35.38 & 28.82 & 18.54 & 32.41 & 12.23 & 14.90 & 136.60 & 0.20 \\
\hline 211 & 07327490 & 207.96 & 106.23 & 48.92 & 32.19 & 8.52 & 33.98 & 217.25 & 0.64 \\
\hline 212 & 07329000 & 139.68 & 46.96 & 66.38 & 35.07 & 9.97 & 32.90 & 246.02 & 0.36 \\
\hline 213 & 07329500 & 201.75 & 101.88 & 49.50 & 35.87 & 8.78 & 47.53 & 312.88 & 0.34 \\
\hline 214 & 07329810 & 18.75 & 18.75 & 0.00 & 37.89 & 41.48 & 13.81 & 429.61 & 0.91 \\
\hline 215 & 07329900 & 136.76 & 96.75 & 29.26 & 38.16 & 13.71 & 28.85 & 296.73 & 1.21 \\
\hline 216 & 07330500 & 296.30 & 164.87 & 44.36 & 36.08 & 5.81 & 51.07 & 222.71 & 0.60 \\
\hline 217 & 07332070 & 0.71 & 0.71 & 0.00 & 41.22 & 27.10 & 1.46 & 29.60 & 0.36 \\
\hline
\end{tabular}


Appendix 1. Basin characteristics computed by Tortorelli (1997) and StreamStats.-Continued

[Ark., Arkansas; Kans., Kansas; Mo., Missouri; N. Mex., New Mexico; Okla., Oklahoma; Tex., Texas; Trib., Tributary; S.H., State Highway; SWS, Subwatershed; NRCS FWR, Natural Resources Conservation Service floodwater retarding]

Tortorelli (1997)

Site

no.

(Tor- Station

tor- no.

elli,

1997)
Station name

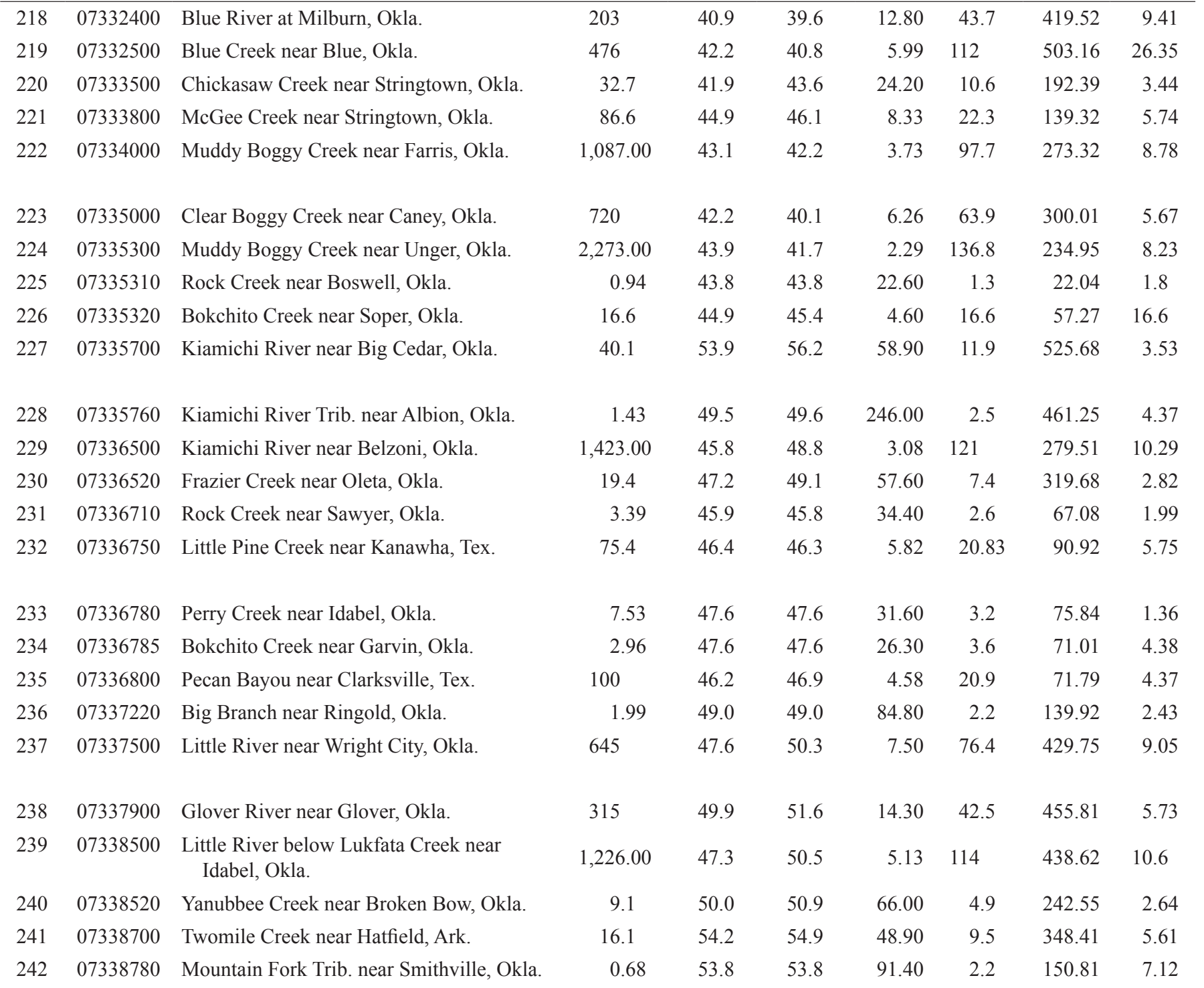


Appendix 1. Basin characteristics computed by Tortorelli (1997) and StreamStats._Continued

[Ark., Arkansas; Kans., Kansas; Mo., Missouri; N. Mex., New Mexico; Okla., Oklahoma; Tex., Texas; Trib., Tributary; S.H., State Highway; SWS, Subwatershed; NRCS FWR, Natural Resources Conservation Service floodwater retarding]

\begin{tabular}{|c|c|c|c|c|c|c|c|c|c|}
\hline \multirow[b]{2}{*}{$\begin{array}{l}\text { Site } \\
\text { no. } \\
\text { (Tor- } \\
\text { tor- } \\
\text { elli, } \\
1997 \text { ) }\end{array}$} & \multirow[b]{2}{*}{$\begin{array}{c}\text { Station } \\
\text { no. }\end{array}$} & \multicolumn{8}{|c|}{ StreamStats } \\
\hline & & $\begin{array}{l}\text { Contribut- } \\
\text { ing drain- } \\
\text { age area, } \\
\text { in square } \\
\text { miles } \\
\text { (CONTDA) }\end{array}$ & $\begin{array}{l}\text { Contrib- } \\
\text { uting drain- } \\
\text { age area } \\
\text { that } \\
\text { is ureg- } \\
\text { ulated } \\
\text { by NRCS } \\
\text { FWR } \\
\text { struc- } \\
\text { tures, in } \\
\text { square } \\
\text { miles } \\
\text { (DAUNREG) }\end{array}$ & $\begin{array}{c}\text { Contrib- } \\
\text { uting } \\
\text { drainage } \\
\text { area that is } \\
\text { regulated } \\
\text { by NRCS } \\
\text { FWR } \\
\text { structures, } \\
\text { in percent } \\
\text { (NRCSPCT) }\end{array}$ & $\begin{array}{c}\text { Outlet } \\
\text { mean } \\
\text { annual } \\
\text { precip- } \\
\text { itation } \\
\text { (1961-1990), } \\
\text { in inches } \\
\text { (PRCOUT61) }\end{array}$ & $\begin{array}{c}\text { 10-85 } \\
\text { channel } \\
\text { slope, } \\
\text { in } \\
\text { feet } \\
\text { per } \\
\text { mile } \\
\text { (CSL10_85fm) }\end{array}$ & $\begin{array}{l}\text { Length } \\
\text { of } \\
\text { longest } \\
\text { flow } \\
\text { path, } \\
\text { in } \\
\text { miles } \\
\text { (L) }\end{array}$ & $\begin{array}{c}10-85 \\
\text { change } \\
\text { in } \\
\text { ele- } \\
\text { vation } \\
\text { of } \\
\text { longest } \\
\text { flow } \\
\text { path, } \\
\text { in feet } \\
\text { ( } \triangle E L E V)\end{array}$ & $\begin{array}{l}\text { Imper- } \\
\text { vious } \\
\text { area, } \\
\text { in } \\
\text { percent } \\
\text { (IM- } \\
\text { PNLCD01) }\end{array}$ \\
\hline 218 & 07332400 & 203.19 & 201.52 & 0.82 & 41.02 & 10.26 & 58.16 & 447.57 & 0.21 \\
\hline 219 & 07332500 & 477.45 & 475.78 & 0.35 & 42.14 & 6.98 & 106.84 & 559.43 & 0.63 \\
\hline 220 & 07333500 & 32.62 & 32.62 & 0.00 & 41.44 & 25.39 & 13.71 & 261.18 & 0.09 \\
\hline 221 & 07333800 & 88.76 & 88.76 & 0.00 & 45.24 & 6.10 & 30.64 & 140.30 & 0.09 \\
\hline 222 & 07334000 & $1,088.92$ & 987.26 & 9.34 & 42.89 & 3.18 & 124.69 & 297.73 & 0.28 \\
\hline 223 & 07335000 & 713.37 & 406.83 & 42.97 & 41.94 & 3.37 & 90.84 & 229.77 & 0.38 \\
\hline 224 & 07335300 & $2,261.85$ & $1,844.45$ & 18.45 & 44.08 & 2.40 & 166.16 & 299.44 & 0.29 \\
\hline 225 & 07335310 & 1.01 & 1.01 & 0.00 & 43.64 & 33.38 & 1.98 & 49.51 & 0.07 \\
\hline 226 & 07335320 & 17.48 & 17.48 & 0.00 & 45.01 & 15.74 & 9.52 & 112.39 & 0.21 \\
\hline 227 & 07335700 & 39.63 & 39.63 & 0.00 & 56.32 & 54.89 & 12.79 & 526.40 & 0.13 \\
\hline 228 & 07335760 & 1.51 & 1.51 & 0.00 & 50.58 & 342.93 & 3.60 & 924.74 & 0.22 \\
\hline 229 & 07336500 & $1,415.94$ & $1,391.77$ & 1.71 & 46.23 & 3.35 & 137.13 & 344.84 & 0.27 \\
\hline 230 & 07336520 & 18.54 & 18.54 & 0.00 & 47.45 & 25.32 & 10.57 & 200.69 & 0.13 \\
\hline 231 & 07336710 & 3.33 & 3.33 & 0.00 & 46.68 & 33.06 & 4.01 & 99.36 & 0.45 \\
\hline 232 & 07336750 & 75.27 & 75.27 & 0.00 & 47.21 & 5.24 & 23.93 & 94.01 & 0.71 \\
\hline 233 & 07336780 & 7.60 & 7.60 & 0.00 & 48.09 & 22.72 & 4.70 & 80.08 & 1.13 \\
\hline 234 & 07336785 & 2.89 & 2.89 & 0.00 & 48.09 & 22.67 & 4.28 & 72.70 & 0.51 \\
\hline 235 & 07336800 & 98.91 & 98.91 & 0.00 & 46.04 & 4.30 & 32.12 & 103.60 & 0.50 \\
\hline 236 & 07337220 & 1.99 & 1.99 & 0.00 & 49.77 & 72.35 & 2.42 & 131.36 & 0.48 \\
\hline 237 & 07337500 & 648.22 & 648.22 & 0.00 & 49.37 & 9.74 & 92.73 & 677.61 & 0.31 \\
\hline 238 & 07337900 & 320.28 & 320.28 & 0.00 & 50.42 & 13.52 & 52.57 & 533.05 & 0.57 \\
\hline 239 & 07338500 & $1,228.14$ & $1,228.14$ & 0.00 & 48.35 & 5.67 & 132.74 & 564.37 & 0.46 \\
\hline 240 & 07338520 & 9.03 & 9.03 & 0.00 & 50.64 & 42.27 & 6.05 & 191.64 & 0.68 \\
\hline 241 & 07338700 & 16.22 & 16.22 & 0.00 & 53.59 & 44.03 & 10.78 & 355.87 & 0.28 \\
\hline 242 & 07338780 & 0.65 & 0.65 & 0.00 & 54.05 & 69.96 & 2.67 & 140.12 & 3.25 \\
\hline
\end{tabular}


Appendix 1. Basin characteristics computed by Tortorelli (1997) and StreamStats.-Continued

[Ark., Arkansas; Kans., Kansas; Mo., Missouri; N. Mex., New Mexico; Okla., Oklahoma; Tex., Texas; Trib., Tributary; S.H., State Highway; SWS, Subwatershed; NRCS FWR, Natural Resources Conservation Service floodwater retarding]

\begin{tabular}{|c|c|c|c|c|c|c|c|c|c|}
\hline \multirow[b]{2}{*}{$\begin{array}{l}\text { Site } \\
\text { no. } \\
\text { (Tor- } \\
\text { tor- } \\
\text { elli, } \\
\text { 1997) }\end{array}$} & \multirow[b]{2}{*}{$\begin{array}{c}\text { Station } \\
\text { no. }\end{array}$} & \multirow[b]{2}{*}{ Station name } & \multicolumn{7}{|c|}{ Tortorelli (1997) } \\
\hline & & & $\begin{array}{c}\text { Con- } \\
\text { trib- } \\
\text { uting } \\
\text { drain- } \\
\text { age } \\
\text { area } \\
\text { in } \\
\text { square } \\
\text { miles }\end{array}$ & $\begin{array}{c}\text { Outlet } \\
\text { mean } \\
\text { annual } \\
\text { precip- } \\
\text { itation } \\
(1961- \\
1990) \text {, } \\
\text { in } \\
\text { inches }\end{array}$ & $\begin{array}{c}\text { Area- } \\
\text { weight- } \\
\text { ed mean } \\
\text { annual } \\
\text { precipi- } \\
\text { tation } \\
(1961- \\
\text { 1990), } \\
\text { in } \\
\text { inches }\end{array}$ & $\begin{array}{c}\text { 10-85 } \\
\text { chan- } \\
\text { nel } \\
\text { slope, } \\
\text { in } \\
\text { feet } \\
\text { per } \\
\text { mile }\end{array}$ & $\begin{array}{l}\text { Stream } \\
\text { length, } \\
\text { in } \\
\text { miles }\end{array}$ & $\begin{array}{c}10-85 \\
\text { change } \\
\text { in } \\
\text { ele- } \\
\text { vation } \\
\text { of } \\
\text { stream, } \\
\text { in } \\
\text { feet }\end{array}$ & $\begin{array}{c}\text { Stream } \\
\text { shape } \\
\text { factor, } \\
\text { dimen- } \\
\text { sion- } \\
\text { less }\end{array}$ \\
\hline 243 & 07339000 & Mountain Fork near Eagletown, Okla. & 787 & 50.0 & 53.7 & 6.63 & 87.5 & 435.09 & 9.73 \\
\hline 244 & 07339500 & Rolling Fork near DeQueen, Ark. & 182 & 52.0 & 53.4 & 18.60 & 35.1 & 489.65 & 6.77 \\
\hline 245 & 07339800 & Pepper Creek near DeQueen, Ark. & 6.41 & 52.7 & 52.7 & 47.70 & 6.4 & 228.96 & 6.39 \\
\hline 246 & 07340200 & West Flat Creek near Foreman, Ark. & 10.6 & 50.0 & 50.1 & 12.00 & 6.78 & 61.02 & 4.34 \\
\hline 247 & 07340300 & Cossatot River near Vandervoort, Ark. & 89.6 & 55.2 & 58.4 & 29.90 & 18.4 & 412.62 & 3.78 \\
\hline 248 & 07340500 & Cossatot River near DeQueen, Ark. & 360 & 52.6 & 56.0 & 15.50 & 53.7 & 624.26 & 8.01 \\
\hline 249 & 07340530 & Mill Slough Trib. near Locksburg, Ark. & 0.64 & 51.7 & 51.7 & 60.50 & 1.97 & 89.39 & 6.06 \\
\hline \multirow[t]{3}{*}{250} & 07341000 & Saline River near Dierks, Ark. & 121 & 53.3 & 56.9 & 21.50 & 35.9 & 578.89 & 10.65 \\
\hline & & MAXIMUM & 787.00 & 55.20 & 58.40 & 60.50 & 87.50 & 624.26 & 10.65 \\
\hline & & MINIMUM & 0.64 & 50.00 & 50.10 & 6.63 & 1.97 & 61.02 & 3.78 \\
\hline
\end{tabular}


Appendix 1. Basin characteristics computed by Tortorelli (1997) and StreamStats.-Continued

[Ark., Arkansas; Kans., Kansas; Mo., Missouri; N. Mex., New Mexico; Okla., Oklahoma; Tex., Texas; Trib., Tributary; S.H., State Highway; SWS, Subwatershed; NRCS FWR, Natural Resources Conservation Service floodwater retarding]

\begin{tabular}{|c|c|c|c|c|c|c|c|c|c|}
\hline \multirow[b]{2}{*}{$\begin{array}{c}\text { Site } \\
\text { no. } \\
\text { (Tor- } \\
\text { tor- } \\
\text { elli, } \\
\text { 1997) }\end{array}$} & \multirow[b]{2}{*}{$\begin{array}{c}\text { Station } \\
\text { no. }\end{array}$} & \multicolumn{8}{|c|}{ StreamStats } \\
\hline & & $\begin{array}{l}\text { Contribut- } \\
\text { ing drain- } \\
\text { age area, } \\
\text { in square } \\
\text { miles } \\
\text { (CONTDA) }\end{array}$ & $\begin{array}{l}\text { Contrib- } \\
\text { uting drain- } \\
\text { age area } \\
\text { that } \\
\text { is ureg- } \\
\text { ulated } \\
\text { by NRCS } \\
\text { FWR } \\
\text { struc- } \\
\text { tures, in } \\
\text { square } \\
\text { miles } \\
\text { (DAUNREG) }\end{array}$ & $\begin{array}{l}\text { Contrib- } \\
\text { uting } \\
\text { drainage } \\
\text { area that is } \\
\text { regulated } \\
\text { by NRCS } \\
\text { FWR } \\
\text { structures, } \\
\text { in percent } \\
\text { (NRCSPCT) }\end{array}$ & $\begin{array}{c}\text { Outlet } \\
\text { mean } \\
\text { annual } \\
\text { precip- } \\
\text { itation } \\
\text { (1961-1990), } \\
\text { in inches } \\
\text { (PRCOUT61) }\end{array}$ & $\begin{array}{c}\text { 10-85 } \\
\text { channel } \\
\text { slope, } \\
\text { in } \\
\text { feet } \\
\text { per } \\
\text { mile } \\
\text { (CSL10_85fm) }\end{array}$ & $\begin{array}{l}\text { Length } \\
\text { of } \\
\text { Iongest } \\
\text { flow } \\
\text { path, } \\
\text { in } \\
\text { miles } \\
\text { (L) }\end{array}$ & $\begin{array}{c}\text { 10-85 } \\
\text { change } \\
\text { in } \\
\text { ele- } \\
\text { vation } \\
\text { of } \\
\text { longest } \\
\text { flow } \\
\text { path, } \\
\text { in feet } \\
\text { ( } \triangle \text { ELEV) }\end{array}$ & $\begin{array}{l}\text { Imper- } \\
\text { vious } \\
\text { area, } \\
\text { in } \\
\text { percent } \\
\text { (IM- } \\
\text { PNLCD01) }\end{array}$ \\
\hline 243 & 07339000 & 799.80 & 799.80 & 0.00 & 50.57 & 6.82 & 97.69 & 499.58 & 0.46 \\
\hline 244 & 07339500 & 183.37 & 183.37 & 0.00 & 52.19 & 17.52 & 42.87 & 563.25 & 0.65 \\
\hline 245 & 07339800 & 6.27 & 6.27 & 0.00 & 52.74 & 41.72 & 7.49 & 234.34 & 0.61 \\
\hline 246 & 07340200 & 10.65 & 10.65 & 0.00 & 50.34 & 10.62 & 7.80 & 62.12 & 0.26 \\
\hline 247 & 07340300 & 89.10 & 89.10 & 0.00 & 56.37 & 28.55 & 21.41 & 458.41 & 0.11 \\
\hline 248 & 07340500 & 361.22 & 361.22 & 0.00 & 52.79 & 15.46 & 60.11 & 696.82 & 0.39 \\
\hline 249 & 07340530 & 0.69 & 0.69 & 0.00 & 52.25 & 55.83 & 2.16 & 90.62 & 5.62 \\
\hline \multirow[t]{3}{*}{250} & 07341000 & 120.21 & 120.21 & 0.00 & 54.17 & 20.90 & 40.78 & 639.09 & 0.47 \\
\hline & & 799.80 & 799.80 & 0.00 & 56.37 & 55.83 & 97.69 & 696.82 & 5.62 \\
\hline & & 0.69 & 0.69 & 0.00 & 50.34 & 6.82 & 2.16 & 62.12 & 0.11 \\
\hline
\end{tabular}


Appendix 2. Peak-flow frequency statistics estimated by using basin characteristics from Tortorelli (1997) and StreamStats. The peak-flow statistics computed by using Tortorelli (1997) basin characteristics will not match those reported in Tortorelli (1997). The peak-flows reported in Tortorelli (1997) were computed from gaged data.

[Ark., Arkansas; Kans., Kansas; Mo., Missouri; N. Mex., New Mexico; Okla., Oklahoma; Tex., Texas; Trib., Tributary; S.H., State Highway; SWS, Subwatershed]

\begin{tabular}{|c|c|c|c|c|c|c|c|c|c|}
\hline \multirow{3}{*}{$\begin{array}{c}\text { Site } \\
\text { no. } \\
\text { (Tor- } \\
\text { tor- } \\
\text { elli, } \\
\text { 1997) }\end{array}$} & \multirow{3}{*}{$\begin{array}{c}\text { Station } \\
\text { no. }\end{array}$} & \multirow{3}{*}{ Station name } & \multicolumn{7}{|c|}{ Tortorelli (1997) } \\
\hline & & & \multicolumn{7}{|c|}{$\begin{array}{l}\text { Estimated rural, unregulated peak-flow statistic (PKx), in cubic feet } \\
\text { per second, for recurrence interval in years }(x)\end{array}$} \\
\hline & & & PK2 & PK5 & PK10 & PK25 & PK50 & PK100 & PK500 \\
\hline 17 & 07148100 & Grouse Creek near Dexter, Kans. & 4,225 & 8,946 & 13,006 & 19,408 & 25,178 & 31,616 & 49,669 \\
\hline 18 & 07148350 & $\begin{array}{l}\text { Salt Fork Arkansas River near Winchester, } \\
\text { Okla. }\end{array}$ & 6,342 & 15,794 & 24,856 & 40,177 & 54,828 & 71,861 & 122,238 \\
\hline 19 & 07148400 & Salt Fork Arkansas River near Alva, Okla. & 7,847 & 19,049 & 29,589 & 47,205 & 63,911 & 83,202 & 139,659 \\
\hline 22 & 07150580 & Sand Creek Trib. near Kremlin, Okla. & 581 & 1,290 & 1,932 & 2,973 & 3,928 & 5,005 & 8,146 \\
\hline 23 & 07150870 & Salt Fork Arkansas River Trib. near Eddy, Okla. & 316 & 690 & 1,026 & 1,568 & 2,061 & 2,614 & 4,229 \\
\hline 24 & 07151500 & Chikaskia River near Corbin, Kans. & 8,758 & 19,454 & 28,897 & 44,057 & 57,959 & 73,659 & 118,037 \\
\hline 26 & 07152000 & Chikaskia River near Blackwell, Okla. & 16,545 & 35,745 & 52,296 & 78,524 & 102,386 & 129,140 & 203,604 \\
\hline 27 & 07152360 & Elm Creek near Foraker, Okla. & 1,297 & 2,726 & 3,964 & 5,923 & 7,687 & 9,649 & 15,234 \\
\hline 28 & 07152410 & Rock Creek near Shidler, Okla. & 962 & 2,036 & 2,976 & 4,472 & 5,828 & 7,337 & 11,676 \\
\hline 29 & 07152520 & Black Bear Creek Trib. near Garber, Okla. & 203 & 450 & 675 & 1,041 & 1,377 & 1,755 & 2,875 \\
\hline 30 & 07152842 & Subwatershed W-4 near Morrison, Okla. & 119 & 262 & 393 & 606 & 802 & 1,022 & 1,678 \\
\hline 31 & 07152846 & Subwatershed W-3 near Morrison, Okla. & 75 & 167 & 251 & 388 & 515 & 657 & 1,085 \\
\hline 32 & 07153000 & Black Bear Creek at Pawnee, Okla. & 8,652 & 17,855 & 25,560 & 37,531 & 48,198 & 60,038 & 92,567 \\
\hline 33 & 07153500 & Dry Cimarron River near Guy, N. Mex. & 2,353 & 7,279 & 12,790 & 23,109 & 33,802 & 46,970 & 89,565 \\
\hline 34 & 07154400 & Carrizozo Creek near Kenton, Okla. & 903 & 2,738 & 4,773 & 8,556 & 12,438 & 17,195 & 32,562 \\
\hline 35 & 07154500 & Cimarron River near Kenton, Okla. & 3,322 & 10,074 & 17,499 & 31,236 & 45,327 & 62,594 & 117,689 \\
\hline 36 & 07155000 & $\begin{array}{l}\text { Cimarron River above Ute Creek near Boise } \\
\text { City, Okla. }\end{array}$ & 3,733 & 11,838 & 21,005 & 38,291 & 56,283 & 78,604 & 150,776 \\
\hline 37 & 07155100 & Cold Springs Creek near Wheeless, Okla. & 198 & 605 & 1,061 & 1,912 & 2,784 & 3,855 & 7,354 \\
\hline 45 & 07157500 & Crooked Creek near Nye, Kans. & 3,721 & 9,728 & 15,666 & 25,878 & 35,715 & 47,328 & 82,069 \\
\hline 46 & 07157550 & West Fork Creek near Knowles, Okla. & 225 & 606 & 1,000 & 1,699 & 2,387 & 3,203 & 5,772 \\
\hline 47 & 07157900 & Cavalry Creek at Coldwater, Kans. & 839 & 2,082 & 3,284 & 5,318 & 7,246 & 9,489 & 16,202 \\
\hline 48 & 07157960 & Buffalo Creek near Lovedale, Okla. & 3,947 & 9,783 & 15,372 & 24,804 & 33,790 & 44,229 & 75,137 \\
\hline 49 & 07158020 & Cimarron River Trib. near Lone Wolf, Okla. & 317 & 774 & 1,217 & 1,967 & 2,679 & 3,502 & 5,998 \\
\hline 50 & 07158080 & Sand Creek Trib. near Waynoka, Okla. & 182 & 451 & 716 & 1,168 & 1,601 & 2,103 & 3,647 \\
\hline 51 & 07158180 & Salt Creek Trib. near Okeene, Okla. & 568 & 1,321 & 2,023 & 3,185 & 4,270 & 5,508 & 9,181 \\
\hline 52 & 07158400 & Salt Creek near Okeene, Okla. & 3,830 & 8,837 & 13,420 & 20,936 & 27,948 & 35,932 & 59,116 \\
\hline 53 & 07158500 & Preacher Creek near Dover, Okla. & 794 & 1,789 & 2,693 & 4,166 & 5,520 & 7,055 & 11,528 \\
\hline 54 & 07158550 & Turkey Creek Trib. near Goltry, Okla. & 389 & 900 & 1,378 & 2,165 & 2,896 & 3,731 & 6,206 \\
\hline 55 & 07159000 & Turkey Creek near Drummond, Okla. & 3,965 & 8,812 & 13,111 & 20,016 & 26,323 & 33,454 & 53,711 \\
\hline 56 & 07159200 & Kingfisher Creek near Kingfisher, Okla. & 3,166 & 7,204 & 10,863 & 16,820 & 22,329 & 28,586 & 46,637 \\
\hline
\end{tabular}


Appendix 2. Peak-flow frequency statistics estimated by using basin characteristics from Tortorelli (1997) and StreamStats. The peak-flow statistics computed by using Tortorelli (1997) basin characteristics will not match those reported in Tortorelli (1997). The peak-flows reported in Tortorelli (1997) were computed from gaged data.-Continued

[Ark., Arkansas; Kans., Kansas; Mo., Missouri; N. Mex., New Mexico; Okla., Oklahoma; Tex., Texas; Trib., Tributary; S.H., State Highway; SWS, Subwatershed]

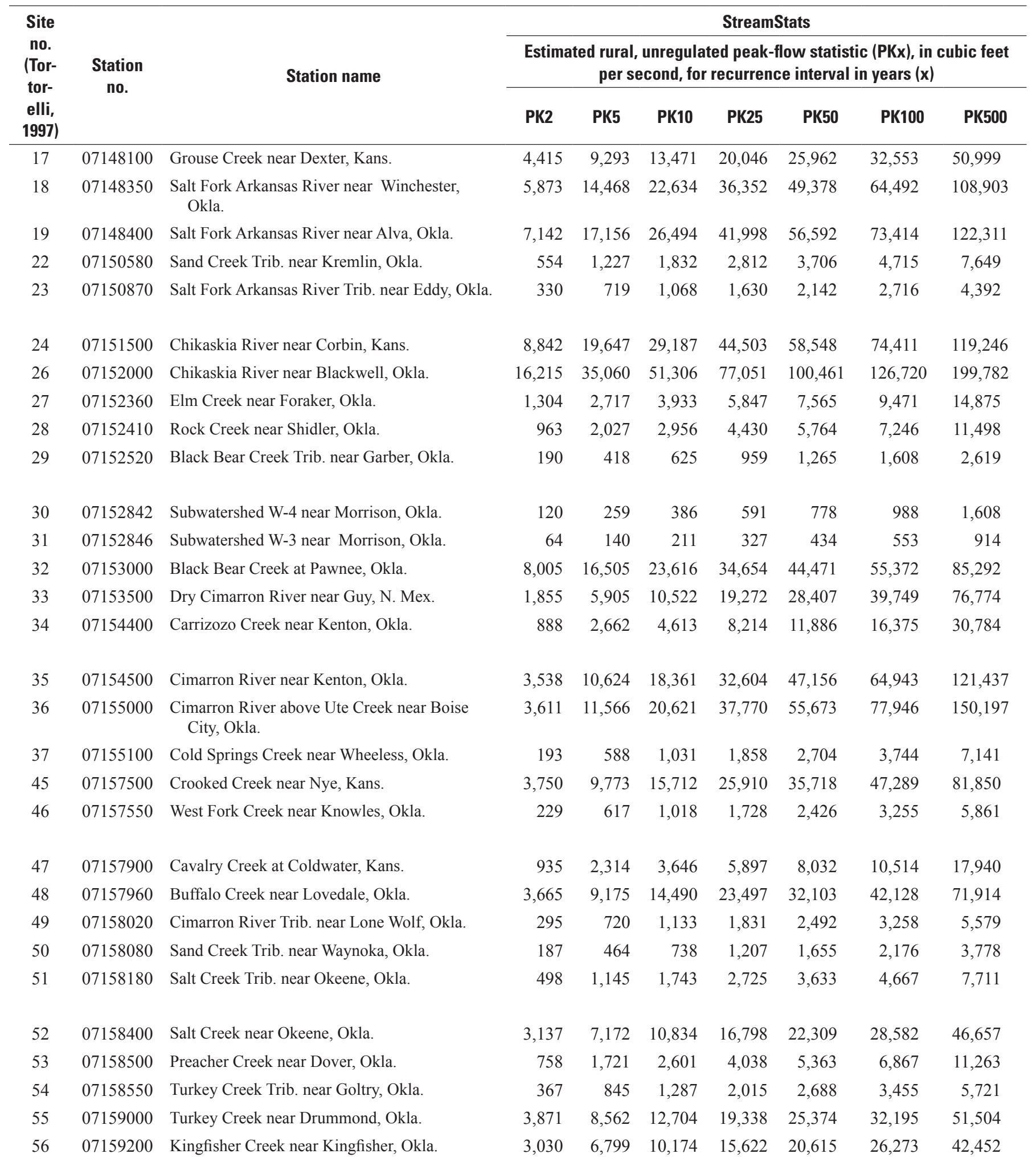


Appendix 2. Peak-flow frequency statistics estimated by using basin characteristics from Tortorelli (1997) and StreamStats. The peak-flow statistics computed by using Tortorelli (1997) basin characteristics will not match those reported in Tortorelli (1997). The peak-flows reported in Tortorelli (1997) were computed from gaged data.-Continued

[Ark., Arkansas; Kans., Kansas; Mo., Missouri; N. Mex., New Mexico; Okla., Oklahoma; Tex., Texas; Trib., Tributary; S.H., State Highway; SWS, Subwatershed]

\begin{tabular}{|c|c|c|c|c|c|c|c|c|c|}
\hline \multirow{2}{*}{$\begin{array}{c}\text { Site } \\
\text { no. } \\
\text { (Tor- } \\
\text { tor- } \\
\text { elli, } \\
\text { 1997) }\end{array}$} & \multirow{2}{*}{$\begin{array}{l}\text { Station } \\
\text { no. }\end{array}$} & \multirow[b]{2}{*}{ Station name } & \multicolumn{7}{|c|}{ Tortorelli (1997) } \\
\hline & & & \multicolumn{7}{|c|}{$\begin{array}{l}\text { Estimated rural, unregulated peak-flow statistic (PKx), in cubic feet per } \\
\text { second, for recurrence interval in years }(x)\end{array}$} \\
\hline 57 & 07159810 & Watershed W-IV near Guthrie, Okla. & 79 & 175 & 264 & 409 & 544 & 696 & 1,152 \\
\hline 60 & 07163000 & Council Creek near Stillwater, Okla. & 1,754 & 3,708 & 5,403 & 8,088 & 10,514 & 13,215 & 20,892 \\
\hline 61 & 07163020 & Corral Creek near Yale, Okla. & 491 & 1,051 & 1,549 & 2,346 & 3,073 & 3,883 & 6,242 \\
\hline 74 & 07171700 & Spring Branch near Cedar Vale, Kans. & 495 & 1,064 & 1,570 & 2,383 & 3,125 & 3,953 & 6,364 \\
\hline 75 & 07171800 & Cedar Creek Trib. near Hooser, Kans. & 214 & 464 & 691 & 1,059 & 1,399 & 1,777 & 2,901 \\
\hline 76 & 07172000 & Caney River near Elgin, Kans. & 9,209 & 18,635 & 26,441 & 38,507 & 49,241 & 61,076 & 93,532 \\
\hline 77 & 07173000 & Caney River near Hulah, Okla. & 10,778 & 22,465 & 32,325 & 47,733 & 61,565 & 76,937 & 119,383 \\
\hline 78 & 07174200 & $\begin{array}{l}\text { Little Caney River below Cotton } \\
\text { Creek near Copan, Okla. }\end{array}$ & 9,423 & 19,453 & 27,881 & 41,021 & 52,800 & 65,848 & 101,897 \\
\hline 79 & 07174570 & Dry Hollow near Pawhuska, Okla. & 426 & 892 & 1,301 & 1,952 & 2,542 & 3,196 & 5,095 \\
\hline 80 & 07174600 & Sand Creek at Okesa, Okla. & 4,873 & 9,969 & 14,257 & 20,939 & 26,919 & 33,522 & 51,893 \\
\hline 85 & 07177500 & Bird Creek near Sperry, Okla. & 13,651 & 27,123 & 38,072 & 54,818 & 69,583 & 85,813 & 129,684 \\
\hline 86 & 07178640 & Bull Creek near Inola, Okla. & 1,176 & 2,307 & 3,242 & 4,680 & 5,943 & 7,324 & 11,170 \\
\hline 89 & 07184000 & Lightning Creek near McCune, Kans. & 5,883 & 11,320 & 15,670 & 22,247 & 27,963 & 34,202 & 51,021 \\
\hline 90 & 07184500 & Labette Creek near Oswego, Kans. & 6,527 & 12,588 & 17,450 & 24,816 & 31,241 & 38,250 & 57,192 \\
\hline 91 & 07184600 & Fly Creek near Faulkner, Kans. & 2,046 & 3,943 & 5,484 & 7,828 & 9,873 & 12,100 & 18,216 \\
\hline 92 & 07185500 & Stahl Creek near Miller, Mo. & 605 & 1,133 & 1,557 & 2,195 & 2,742 & 3,335 & 4,961 \\
\hline 94 & 07185700 & Spring River at LaRussell, Mo. & 10,025 & 19,179 & 26,483 & 37,544 & 47,237 & 57,763 & 86,190 \\
\hline 96 & 07186000 & Spring River near Waco, Mo. & 20,105 & 38,675 & 53,418 & 75,711 & 95,254 & 116,534 & 173,447 \\
\hline 97 & 07186400 & Center Creek near Carterville, Mo. & 8,201 & 15,713 & 21,721 & 30,824 & 38,793 & 47,454 & 70,884 \\
\hline 98 & 07187000 & Shoal Creek above Joplin, Mo. & 11,520 & 22,066 & 30,469 & 43,188 & 54,329 & 66,438 & 99,056 \\
\hline 99 & 07188000 & Spring River near Quapaw, Okla. & 34,074 & 64,722 & 88,728 & 124,814 & 156,380 & 190,638 & 281,384 \\
\hline
\end{tabular}


Appendix 2. Peak-flow frequency statistics estimated by using basin characteristics from Tortorelli (1997) and StreamStats. The peak-flow statistics computed by using Tortorelli (1997) basin characteristics will not match those reported in Tortorelli (1997). The peak-flows reported in Tortorelli (1997) were computed from gaged data.-Continued

[Ark., Arkansas; Kans., Kansas; Mo., Missouri; N. Mex., New Mexico; Okla., Oklahoma; Tex., Texas; Trib., Tributary; S.H., State Highway; SWS, Subwatershed]

\begin{tabular}{|c|c|c|c|c|c|c|c|c|c|}
\hline \multirow{3}{*}{$\begin{array}{l}\text { Site } \\
\text { no. } \\
\text { (Tor- } \\
\text { tor- } \\
\text { elli, } \\
\text { 1997) }\end{array}$} & \multirow{3}{*}{$\begin{array}{l}\text { Station } \\
\text { no. }\end{array}$} & \multirow{3}{*}{ Station name } & \multicolumn{7}{|c|}{ StreamStats } \\
\hline & & & \multicolumn{7}{|c|}{$\begin{array}{l}\text { Estimated rural, unregulated peak-flow statistic (PKx), in cubic feet per } \\
\text { second, for recurrence interval in years }(x)\end{array}$} \\
\hline & & & PK2 & PK5 & PK10 & PK25 & PK50 & PK100 & PK500 \\
\hline 57 & 07159810 & Watershed W-IV near Guthrie, Okla. & 80 & 179 & 271 & 422 & 562 & 719 & 1,194 \\
\hline 58 & 07160500 & Skeleton Creek near Lovell, Okla. & 5,495 & 12,177 & 18,079 & 27,540 & 36,179 & 45,939 & 73,555 \\
\hline 59 & 07160550 & $\begin{array}{l}\text { West Beaver Creek near Orlando, } \\
\text { Okla. }\end{array}$ & 885 & 1,955 & 2,917 & 4,471 & 5,895 & 7,499 & 12,152 \\
\hline 60 & 07163000 & Council Creek near Stillwater, Okla. & 1,648 & 3,478 & 5,065 & 7,573 & 9,835 & 12,353 & 19,501 \\
\hline 61 & 07163020 & Corral Creek near Yale, Okla. & 489 & 1,045 & 1,538 & 2,327 & 3,045 & 3,846 & 6,173 \\
\hline 62 & 07165550 & Snake Creek near Bixby, Okla. & 2,642 & 5,251 & 7,412 & 10,740 & 13,678 & 16,903 & 25,825 \\
\hline 72 & 07170700 & Big Hill Creek near Cherryvale, Kans. & 2,578 & 4,955 & 6,880 & 9,806 & 12,360 & 15,140 & 22,756 \\
\hline 73 & 07170800 & Mud Creek near Mound Valley, Kans. & 866 & 1,675 & 2,342 & 3,366 & 4,266 & 5,244 & 7,982 \\
\hline 74 & 07171700 & Spring Branch near Cedar Vale, Kans. & 473 & 1,018 & 1,503 & 2,281 & 2,990 & 3,782 & 6,088 \\
\hline 75 & 07171800 & Cedar Creek Trib. near Hooser, Kans. & 191 & 417 & 625 & 962 & 1,273 & 1,622 & 2,660 \\
\hline 76 & 07172000 & Caney River near Elgin, Kans. & 8,847 & 17,924 & 25,448 & 37,080 & 47,425 & 58,839 & 90,147 \\
\hline 77 & 07173000 & Caney River near Hulah, Okla. & 10,022 & 20,908 & 30,093 & 44,441 & 57,304 & 71,609 & 111,082 \\
\hline 78 & 07174200 & $\begin{array}{l}\text { Little Caney River below Cotton Creek } \\
\text { near Copan, Okla. }\end{array}$ & 8,549 & 17,533 & 25,030 & 36,660 & 47,016 & 58,487 & 89,993 \\
\hline 79 & 07174570 & Dry Hollow near Pawhuska, Okla. & 431 & 904 & 1,320 & 1,983 & 2,585 & 3,252 & 5,190 \\
\hline 80 & 07174600 & Sand Creek at Okesa, Okla. & 4,532 & 9,257 & 13,225 & 19,396 & 24,902 & 30,985 & 47,867 \\
\hline 81 & 07174720 & $\begin{array}{l}\text { Hogshooter Creek Trib. near Bartles- } \\
\text { ville, Okla. }\end{array}$ & 258 & 536 & 781 & 1,169 & 1,520 & 1,908 & 3,037 \\
\hline 82 & 07176500 & Bird Creek at Avant, Okla. & 8,237 & 16,487 & 23,267 & 33,695 & 42,922 & 53,074 & 80,806 \\
\hline 83 & 07176800 & Candy Creek near Wolco, Okla. & 2,070 & 4,197 & 5,989 & 8,778 & 11,263 & 14,000 & 21,664 \\
\hline 84 & 07177000 & Hominy Creek near Skiatook, Okla. & 7,230 & 14,519 & 20,520 & 29,752 & 37,907 & 46,896 & 71,447 \\
\hline 85 & 07177500 & Bird Creek near Sperry, Okla. & 13,948 & 27,572 & 38,604 & 55,442 & 70,263 & 86,535 & 130,438 \\
\hline 86 & 07178640 & Bull Creek near Inola, Okla. & 1,220 & 2,388 & 3,354 & 4,836 & 6,138 & 7,560 & 11,520 \\
\hline 89 & 07184000 & Lightning Creek near McCune, Kans. & 5,796 & 11,181 & 15,499 & 22,032 & 27,716 & 33,923 & 50,672 \\
\hline 90 & 07184500 & Labette Creek near Oswego, Kans. & 6,393 & 12,256 & 16,934 & 23,997 & 30,135 & 36,827 & 54,843 \\
\hline 91 & 07184600 & Fly Creek near Faulkner, Kans. & 2,078 & 4,007 & 5,573 & 7,957 & 10,037 & 12,304 & 18,529 \\
\hline 92 & 07185500 & Stahl Creek near Miller, Mo. & 834 & 1,604 & 2,239 & 3,211 & 4,064 & 4,990 & 7,581 \\
\hline 94 & 07185700 & Spring River at LaRussell, Mo. & 9,265 & 17,605 & 24,216 & 34,179 & 42,858 & 52,282 & 77,595 \\
\hline 96 & 07186000 & Spring River near Waco, Mo. & 17,119 & 32,645 & 44,854 & 63,186 & 79,093 & 96,427 & 142,392 \\
\hline 97 & 07186400 & Center Creek near Carterville, Mo. & 7,894 & 15,123 & 20,900 & 29,648 & 37,298 & 45,615 & 68,094 \\
\hline 98 & 07187000 & Shoal Creek above Joplin, Mo. & 11,193 & 21,321 & 29,348 & 41,452 & 52,006 & 63,475 & 94,234 \\
\hline 99 & 07188000 & Spring River near Quapaw, Okla. & 28,867 & 54,024 & 73,435 & 102,321 & 127,251 & 154,308 & 225,121 \\
\hline
\end{tabular}


Appendix 2. Peak-flow frequency statistics estimated by using basin characteristics from Tortorelli (1997) and StreamStats. The peak-flow statistics computed by using Tortorelli (1997) basin characteristics will not match those reported in Tortorelli (1997). The peak-flows reported in Tortorelli (1997) were computed from gaged data.-Continued

[Ark., Arkansas; Kans., Kansas; Mo., Missouri; N. Mex., New Mexico; Okla., Oklahoma; Tex., Texas; Trib., Tributary; S.H., State Highway; SWS, Subwatershed]

\begin{tabular}{|c|c|c|c|c|c|c|c|c|c|}
\hline \multirow{3}{*}{$\begin{array}{c}\text { Site } \\
\text { no. } \\
\text { (Tor- } \\
\text { tor- } \\
\text { elli, } \\
\text { 1997) }\end{array}$} & \multirow{3}{*}{$\begin{array}{l}\text { Station } \\
\text { no. }\end{array}$} & \multirow{3}{*}{ Station name } & \multicolumn{7}{|c|}{ Tortorelli (1997) } \\
\hline & & & \multicolumn{7}{|c|}{$\begin{array}{l}\text { Estimated rural, unregulated peak-flow statistic (PKx), in cubic } \\
\text { feet per second, for recurrence interval in years }(x)\end{array}$} \\
\hline & & & PK2 & PK5 & PK10 & PK25 & PK50 & PK100 & PK500 \\
\hline 100 & 07188140 & Flint Branch near Peoria, Okla. & 1,065 & 2,074 & 2,913 & 4,208 & 5,356 & 6,604 & 10,118 \\
\hline 101 & 07188500 & Lost Creek at Seneca, Mo. & 3,383 & 6,565 & 9,167 & 13,153 & 16,675 & 20,504 & 31,087 \\
\hline 102 & 07188900 & Butler Creek Trib. near Gravette, Ark. & 464 & 895 & 1,255 & 1,810 & 2,302 & 2,834 & 4,349 \\
\hline 103 & 07189000 & Elk River near Tiff City, Mo. & 17,689 & 34,114 & 47,212 & 67,066 & 84,515 & 103,511 & 154,545 \\
\hline 104 & 07190600 & Big Cabin Creek near Pyramid Corners, Okla. & 3,745 & 7,219 & 10,027 & 14,294 & 18,024 & 22,087 & 33,177 \\
\hline 105 & 07191000 & Big Cabin Creek near Big Cabin, Okla. & 11,312 & 21,592 & 29,747 & 42,049 & 52,779 & 64,445 & 95,737 \\
\hline 106 & 07191220 & Spavinaw Creek near Sycamore, Okla. & 7,087 & 13,523 & 18,686 & 26,525 & 33,420 & 40,888 & 61,230 \\
\hline 107 & 07191260 & Brushy Creek near Jay, Okla. & 2,039 & 3,918 & 5,454 & 7,802 & 9,870 & 12,112 & 18,333 \\
\hline 108 & 07192000 & Pryor Creek near Pryor, Okla. & 6,820 & 13,272 & 18,482 & 26,407 & 33,349 & 40,935 & 61,507 \\
\hline 109 & 07194515 & Mill Creek near Park Hill, Okla. & 813 & 1,584 & 2,228 & 3,225 & 4,113 & 5,076 & 7,808 \\
\hline 110 & 07195000 & Osage Creek near Elm Springs, Ark. & 7,032 & 13,288 & 18,270 & 25,802 & 32,398 & 39,528 & 58,872 \\
\hline 111 & 07195200 & Brush Creek Trib. near Tontitown, Ark. & 255 & 492 & 692 & 999 & 1,272 & 1,566 & 2,410 \\
\hline 112 & 07195450 & Ballard Creek at Summers, Ark. & 2,250 & 4,235 & 5,836 & 8,266 & 10,399 & 12,696 & 19,042 \\
\hline 113 & 07195500 & Illinois River near Watts, Okla. & 17,035 & 31,801 & 43,325 & 60,588 & 75,617 & 91,843 & 135,049 \\
\hline 114 & 07195800 & Flint Creek at Springtown, Ark. & 1,933 & 3,640 & 5,015 & 7,098 & 8,918 & 10,881 & 16,289 \\
\hline 115 & 07196000 & Flint Creek near Kansas, Okla. & 6,516 & 12,323 & 16,956 & 23,967 & 30,114 & 36,757 & 54,818 \\
\hline 116 & 07196380 & Steely Hollow near Tahlequah, Okla. & 1,051 & 2,028 & 2,838 & 4,086 & 5,196 & 6,395 & 9,783 \\
\hline 117 & 07196500 & Illinois River near Tahlequah, Okla. & 19,911 & 37,136 & 50,514 & 70,498 & 87,837 & 106,579 & 156,189 \\
\hline 118 & 07196900 & Baron Fork at Dutch Mills, Ark. & 4,647 & 8,711 & 11,956 & 16,872 & 21,189 & 25,834 & 38,552 \\
\hline 119 & 07197000 & Baron Fork at Eldon, Okla. & 11,443 & 21,594 & 29,625 & 41,736 & 52,338 & 63,799 & 94,664 \\
\hline 120 & 07228290 & Rough Creek near Thomas, Okla. & 622 & 1,486 & 2,307 & 3,684 & 4,984 & 6,478 & 10,955 \\
\hline 121 & 07228450 & Deer Creek Trib. near Hydro, Okla. & 286 & 671 & 1,037 & 1,647 & 2,220 & 2,876 & 4,850 \\
\hline 122 & 07228930 & Worley Creek near Tuttle, Okla. & 865 & 1,869 & 2,758 & 4,182 & 5,476 & 6,926 & 11,103 \\
\hline 123 & 07228960 & Canadian River Trib. near Newcastle, Okla. & 478 & 1,045 & 1,554 & 2,378 & 3,132 & 3,979 & 6,457 \\
\hline 124 & 07229220 & Walnut Creek near Blanchard, Okla. & 279 & 613 & 915 & 1,406 & 1,857 & 2,363 & 3,858 \\
\hline 125 & 07229300 & Walnut Creek near Purcell, Okla. & 5,363 & 11,001 & 15,735 & 23,100 & 29,671 & 36,943 & 57,080 \\
\hline 126 & 07229420 & Julian Creek Trib. near Asher, Okla. & 450 & 931 & 1,347 & 2,005 & 2,596 & 3,250 & 5,128 \\
\hline 127 & 07229430 & Arbeca Creek near Allen, Okla. & 478 & 961 & 1,371 & 2,012 & 2,580 & 3,205 & 4,982 \\
\hline 128 & 07230000 & $\begin{array}{l}\text { Little River below Lake Thunderbird near Nor- } \\
\text { man, Okla. }\end{array}$ & 5,660 & 11,661 & 16,705 & 24,553 & 31,548 & 39,305 & 60,746 \\
\hline 129 & 07230500 & Little River near Tecumseh, Okla. & 8,482 & 17,077 & 24,156 & 35,050 & 44,684 & 55,310 & 84,298 \\
\hline
\end{tabular}


Appendix 2. Peak-flow frequency statistics estimated by using basin characteristics from Tortorelli (1997) and StreamStats. The peak-flow statistics computed by using Tortorelli (1997) basin characteristics will not match those reported in Tortorelli (1997). The peak-flows reported in Tortorelli (1997) were computed from gaged data.-Continued

[Ark., Arkansas; Kans., Kansas; Mo., Missouri; N. Mex., New Mexico; Okla., Oklahoma; Tex., Texas; Trib., Tributary; S.H., State Highway; SWS, Subwatershed]

\begin{tabular}{|c|c|c|c|c|c|c|c|c|c|}
\hline \multirow{3}{*}{$\begin{array}{c}\text { Site } \\
\text { no. } \\
\text { (Tor- } \\
\text { tor- } \\
\text { elli, } \\
\text { 1997) }\end{array}$} & \multirow{3}{*}{$\begin{array}{c}\text { Station } \\
\text { no. }\end{array}$} & \multirow{3}{*}{ Station name } & \multicolumn{7}{|c|}{ StreamStats } \\
\hline & & & \multicolumn{7}{|c|}{$\begin{array}{l}\text { Estimated rural, unregulated peak-flow statistic (PKx), in cubic } \\
\text { feet per second, for recurrence interval in years }(x)\end{array}$} \\
\hline & & & PK2 & PK5 & PK10 & PK25 & PK50 & PK100 & PK500 \\
\hline 100 & 07188140 & Flint Branch near Peoria, Okla. & 968 & 1,875 & 2,624 & 3,775 & 4,789 & 5,891 & 8,980 \\
\hline 101 & 07188500 & Lost Creek at Seneca, Mo. & 3,311 & 6,395 & 8,908 & 12,748 & 16,133 & 19,811 & 29,953 \\
\hline 102 & 07188900 & Butler Creek Trib. near Gravette, Ark. & 497 & 956 & 1,339 & 1,929 & 2,453 & 3,018 & 4,627 \\
\hline 103 & 07189000 & Elk River near Tiff City, Mo. & 17,893 & 34,022 & 46,747 & 65,918 & 82,672 & 100,857 & 149,428 \\
\hline 104 & 07190600 & Big Cabin Creek near Pyramid Corners, Okla. & 3,829 & 7,411 & 10,316 & 14,741 & 18,620 & 22,847 & 34,412 \\
\hline 105 & 07191000 & Big Cabin Creek near Big Cabin, Okla. & 10,838 & 20,665 & 28,449 & 40,176 & 50,382 & 61,485 & 91,212 \\
\hline 106 & 07191220 & Spavinaw Creek near Sycamore, Okla. & 6,976 & 13,113 & 17,978 & 25,314 & 31,720 & 38,638 & 57,353 \\
\hline 107 & 07191260 & Brushy Creek near Jay, Okla. & 2,033 & 3,896 & 5,414 & 7,731 & 9,767 & 11,975 & 18,087 \\
\hline 108 & 07192000 & Pryor Creek near Pryor, Okla. & 6,568 & 12,628 & 17,472 & 24,794 & 31,162 & 38,110 & 56,827 \\
\hline 109 & 07194515 & Mill Creek near Park Hill, Okla. & 703 & 1,370 & 1,928 & 2,793 & 3,563 & 4,398 & 6,769 \\
\hline 110 & 07195000 & Osage Creek near Elm Springs, Ark. & 6,942 & 13,110 & 18,018 & 25,436 & 31,928 & 38,945 & 57,970 \\
\hline 111 & 07195200 & Brush Creek Trib. near Tontitown, Ark. & 264 & 512 & 720 & 1,043 & 1,328 & 1,638 & 2,526 \\
\hline 112 & 07195450 & Ballard Creek at Summers, Ark. & 2,204 & 4,166 & 5,753 & 8,168 & 10,291 & 12,579 & 18,912 \\
\hline 113 & 07195500 & Illinois River near Watts, Okla. & 16,325 & 30,349 & 41,250 & 57,536 & 71,667 & 86,920 & 127,415 \\
\hline 114 & 07195800 & Flint Creek at Springtown, Ark. & 2,167 & 4,103 & 5,670 & 8,054 & 10,149 & 12,409 & 18,661 \\
\hline 115 & 07196000 & Flint Creek near Kansas, Okla. & 6,677 & 12,499 & 17,105 & 24,043 & 30,096 & 36,625 & 54,285 \\
\hline 116 & 07196380 & Steely Hollow near Tahlequah, Okla. & 1,020 & 1,965 & 2,747 & 3,951 & 5,018 & 6,172 & 9,424 \\
\hline 117 & 07196500 & Illinois River near Tahlequah, Okla. & 19,138 & 35,681 & 48,518 & 67,680 & 84,279 & 102,231 & 149,697 \\
\hline 118 & 07196900 & Baron Fork at Dutch Mills, Ark. & 4,427 & 8,246 & 11,285 & 15,877 & 19,901 & 24,224 & 36,044 \\
\hline 119 & 07197000 & Baron Fork at Eldon, Okla. & 11,085 & 20,836 & 28,519 & 40,076 & 50,158 & 61,056 & 90,315 \\
\hline 120 & 07228290 & Rough Creek near Thomas, Okla. & 615 & 1,466 & 2,274 & 3,626 & 4,901 & 6,365 & 10,749 \\
\hline 121 & 07228450 & Deer Creek Trib. near Hydro, Okla. & 292 & 686 & 1,059 & 1,681 & 2,265 & 2,933 & 4,942 \\
\hline 122 & 07228930 & Worley Creek near Tuttle, Okla. & 860 & 1,851 & 2,726 & 4,123 & 5,390 & 6,808 & 10,887 \\
\hline 123 & 07228960 & Canadian River Trib. near Newcastle, Okla. & 471 & 1,025 & 1,522 & 2,323 & 3,055 & 3,876 & 6,275 \\
\hline 124 & 07229220 & Walnut Creek near Blanchard, Okla. & 282 & 617 & 920 & 1,411 & 1,861 & 2,366 & 3,854 \\
\hline 125 & 07229300 & Walnut Creek near Purcell, Okla. & 5,334 & 10,871 & 15,498 & 22,673 & 29,054 & 36,108 & 55,579 \\
\hline 126 & 07229420 & Julian Creek Trib. near Asher, Okla. & 437 & 899 & 1,299 & 1,927 & 2,490 & 3,112 & 4,896 \\
\hline 127 & 07229430 & Arbeca Creek near Allen, Okla. & 468 & 943 & 1,348 & 1,981 & 2,544 & 3,162 & 4,927 \\
\hline 128 & 07230000 & $\begin{array}{l}\text { Little River below Lake Thunderbird near } \\
\text { Norman, Okla. }\end{array}$ & 5,773 & 11,908 & 17,071 & 25,111 & 32,287 & 40,245 & 62,263 \\
\hline 129 & 07230500 & Little River near Tecumseh, Okla. & 8,871 & 17,940 & 25,440 & 37,014 & 47,285 & 58,618 & 89,630 \\
\hline
\end{tabular}


Appendix 2. Peak-flow frequency statistics estimated by using basin characteristics from Tortorelli (1997) and StreamStats. The peak-flow statistics computed by using Tortorelli (1997) basin characteristics will not match those reported in Tortorelli (1997). The peak-flows reported in Tortorelli (1997) were computed from gaged data.-Continued

[Ark., Arkansas; Kans., Kansas; Mo., Missouri; N. Mex., New Mexico; Okla., Oklahoma; Tex., Texas; Trib., Tributary; S.H., State Highway; SWS, Subwatershed]

\begin{tabular}{|c|c|c|c|c|c|c|c|c|c|}
\hline \multirow{3}{*}{$\begin{array}{c}\text { Site } \\
\text { no. } \\
\text { (Tor- } \\
\text { tor- } \\
\text { elli, } \\
\text { 1997) }\end{array}$} & \multirow{3}{*}{$\begin{array}{l}\text { Station } \\
\text { no. }\end{array}$} & \multirow{3}{*}{ Station name } & \multicolumn{7}{|c|}{ Tortorelli (1997) } \\
\hline & & & \multicolumn{7}{|c|}{$\begin{array}{l}\text { Estimated rural, unregulated peak-flow statistic (PKx), in cubic } \\
\text { feet per second, for recurrence interval in years }(x)\end{array}$} \\
\hline & & & PK2 & PK5 & PK10 & PK25 & PK50 & PK100 & PK500 \\
\hline 130 & 07231000 & Little River near Sasakwa, Okla. & 12,670 & 25,280 & 35,560 & 51,301 & 65,181 & 80,462 & 121,811 \\
\hline 131 & 07231320 & Leader Creek Trib. near Atwood, Okla. & 283 & 575 & 828 & 1,225 & 1,581 & 1,972 & 3,103 \\
\hline 132 & 07231560 & Middle Creek near Carson, Okla. & 1,011 & 2,006 & 2,839 & 4,128 & 5,268 & 6,517 & 10,027 \\
\hline 133 & 07231950 & Pine Creek near Higgins, Okla. & 2,055 & 3,824 & 5,244 & 7,398 & 9,286 & 11,311 & 16,914 \\
\hline 134 & 07232000 & Gaines Creek near Krebs, Okla. & 13,707 & 25,879 & 35,441 & 49,796 & 62,273 & 75,806 & 111,880 \\
\hline 135 & 07232500 & Beaver River near Guymon, Okla. & 3,659 & 10,740 & 18,341 & 32,169 & 46,147 & 63,137 & 116,495 \\
\hline 136 & 07232650 & Aqua Frio Creek near Felt, Okla. & 348 & 1,066 & 1,873 & 3,380 & 4,926 & 6,829 & 13,023 \\
\hline 137 & 07233000 & Coldwater Creek near Hardesty, Okla. & 3,035 & 8,645 & 14,550 & 25,143 & 35,720 & 48,477 & 88,117 \\
\hline 138 & 07233500 & Palo Duro Creek near Spearman, Tex. & 2,178 & 6,144 & 10,294 & 17,709 & 25,075 & 33,938 & 61,427 \\
\hline 139 & 07234050 & North Fork Clear Creek near Balko, Okla. & 176 & 484 & 806 & 1,381 & 1,947 & 2,624 & 4,760 \\
\hline 140 & 07234100 & Clear Creek near Elmwood, Okla. & 1,676 & 4,491 & 7,351 & 12,356 & 17,253 & 23,062 & 40,863 \\
\hline 141 & 07234150 & White Woman Creek Trib. near Darrouzett, Tex. & 172 & 441 & 710 & 1,172 & 1,614 & 2,133 & 3,724 \\
\hline 142 & 07234290 & Clear Creek Trib. near Catesby, Okla. & 338 & 893 & 1,458 & 2,448 & 3,414 & 4,554 & 8,095 \\
\hline 143 & 07235000 & Wolf Creek at Lipscomb, Tex. & 2,962 & 7,904 & 12,882 & 21,555 & 30,015 & 40,042 & 70,500 \\
\hline 144 & 07235700 & Little Wolf Creek Trib. near Gage, Okla. & 469 & 1,248 & 2,043 & 3,435 & 4,795 & 6,404 & 11,388 \\
\hline 145 & 07236000 & Wolf Creek near Fargo, Okla. & 6,522 & 16,810 & 26,878 & 44,117 & 60,740 & 80,261 & 138,427 \\
\hline 146 & 07237750 & Cottonwood Creek near Vici, Okla. & 550 & 1,369 & 2,170 & 3,536 & 4,843 & 6,362 & 10,976 \\
\hline 147 & 07237800 & Bent Creek near Seiling, Okla. & 2,229 & 5,477 & 8,586 & 13,825 & 18,804 & 24,573 & 41,723 \\
\hline 148 & 07239050 & $\begin{array}{l}\text { North Canadian River Trib. near Eagle City, } \\
\text { Okla. }\end{array}$ & 117 & 281 & 441 & 712 & 969 & 1,265 & 2,175 \\
\hline 149 & 07241880 & Sand Creek near Cromwell, Okla. & 1,094 & 2,245 & 3,230 & 4,777 & 6,165 & 7,696 & 12,049 \\
\hline 150 & 07242160 & Alabama Creek near Weleetka, Okla. & 1,625 & 3,273 & 4,663 & 6,828 & 8,758 & 10,879 & 16,847 \\
\hline 151 & 07243000 & Dry Creek near Kendrick, Okla. & 2,704 & 5,689 & 8,259 & 12,312 & 15,963 & 20,026 & 31,480 \\
\hline 152 & 07243500 & Deep Fork near Beggs, Okla. & 21,439 & 42,053 & 58,555 & 83,592 & 105,532 & 129,601 & 193,855 \\
\hline 153 & 07243550 & Adams Creek near Beggs, Okla. & 889 & 1,793 & 2,561 & 3,760 & 4,829 & 6,004 & 9,336 \\
\hline 154 & 07244000 & Deep Fork near Dewar, Okla. & 23,081 & 44,658 & 61,725 & 87,445 & 109,836 & 134,344 & 199,259 \\
\hline 155 & 07244790 & Brooken Creek near Enterprise, Okla. & 1,106 & 2,137 & 2,989 & 4,297 & 5,451 & 6,704 & 10,213 \\
\hline 156 & 07245500 & Sallisaw Creek near Sallisaw, Okla. & 8,228 & 15,645 & 21,563 & 30,525 & 38,386 & 46,898 & 69,975 \\
\hline 157 & 07246610 & Pecan Creek near Spiro, Okla. & 373 & 714 & 996 & 1,429 & 1,809 & 2,220 & 3,382 \\
\hline 158 & 07246630 & Big Black Fox Creek near Long, Okla. & 1,271 & 2,424 & 3,369 & 4,817 & 6,094 & 7,473 & 11,335 \\
\hline 159 & 07247000 & Poteau River at Cauthron, Ark. & 11,355 & 19,969 & 26,454 & 35,978 & 44,125 & 52,787 & 75,594 \\
\hline
\end{tabular}


Appendix 2. Peak-flow frequency statistics estimated by using basin characteristics from Tortorelli (1997) and StreamStats. The peak-flow statistics computed by using Tortorelli (1997) basin characteristics will not match those reported in Tortorelli (1997). The peak-flows reported in Tortorelli (1997) were computed from gaged data.-Continued

[Ark., Arkansas; Kans., Kansas; Mo., Missouri; N. Mex., New Mexico; Okla., Oklahoma; Tex., Texas; Trib., Tributary; S.H., State Highway; SWS, Subwatershed]

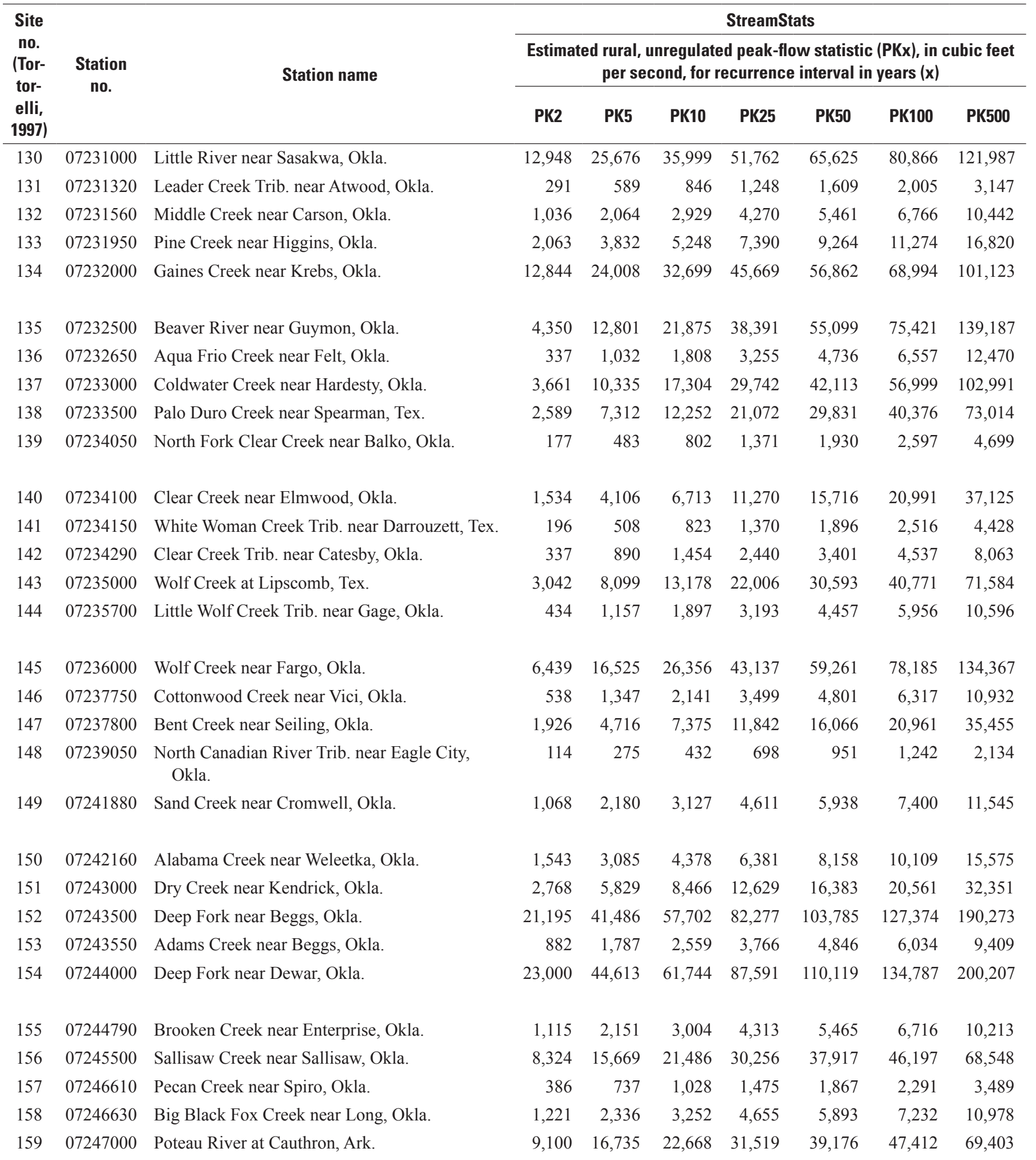


Appendix 2. Peak-flow frequency statistics estimated by using basin characteristics from Tortorelli (1997) and StreamStats. The peak-flow statistics computed by using Tortorelli (1997) basin characteristics will not match those reported in Tortorelli (1997). The peak-flows reported in Tortorelli (1997) were computed from gaged data.-Continued

[Ark., Arkansas; Kans., Kansas; Mo., Missouri; N. Mex., New Mexico; Okla., Oklahoma; Tex., Texas; Trib., Tributary; S.H., State Highway; SWS, Subwatershed]

\begin{tabular}{|c|c|c|c|c|c|c|c|c|c|}
\hline \multirow{3}{*}{$\begin{array}{c}\text { Site } \\
\text { no. } \\
\text { (Tor- } \\
\text { tor- } \\
\text { elli, } \\
\text { 1997) }\end{array}$} & \multirow{3}{*}{$\begin{array}{l}\text { Station } \\
\text { no. }\end{array}$} & \multirow{3}{*}{ Station name } & \multicolumn{7}{|c|}{ Tortorelli (1997) } \\
\hline & & & \multicolumn{7}{|c|}{$\begin{array}{l}\text { Estimated rural, unregulated peak-flow statistic (PKx), in cubic } \\
\text { feet per second, for recurrence interval in years }(x)\end{array}$} \\
\hline & & & PK2 & PK5 & PK10 & PK25 & PK50 & PK100 & PK500 \\
\hline 160 & 07247500 & Fourche Maline near Red Oak, Okla. & 6,137 & 11,025 & 14,759 & 20,265 & 24,957 & 29,990 & 43,303 \\
\hline 161 & 07249000 & Poteau River at Poteau, Okla. & 22,530 & 41,543 & 56,143 & 77,817 & 96,507 & 116,681 & 169,643 \\
\hline 162 & 07249300 & James Fork near Midland, Ark. & 4,463 & 8,450 & 11,659 & 16,541 & 20,846 & 25,488 & 38,253 \\
\hline 163 & 07249400 & James Fork near Hackett, Ark. & 7,172 & 13,606 & 18,737 & 26,499 & 33,297 & 40,656 & 60,610 \\
\hline 164 & 07249500 & Cove Creek near Lee Creek, Ark. & 4,146 & 7,654 & 10,430 & 14,611 & 18,263 & 22,177 & 32,856 \\
\hline 165 & 07249650 & Mountain Fork near Evansville, Ark. & 1,842 & 3,441 & 4,730 & 6,690 & 8,411 & 10,259 & 15,388 \\
\hline 166 & 07250000 & Lee Creek near Van Buren, Ark. & 14,796 & 27,947 & 38,348 & 54,052 & 67,842 & 82,739 & 122,848 \\
\hline 169 & 07299670 & Groesbeck Creek at S.H. 6 near Quannah, Tex. & 2,923 & 7,242 & 11,378 & 18,347 & 24,959 & 32,648 & 55,384 \\
\hline 170 & 07299705 & Bitter Creek near Hollis, Okla. & 446 & 1,157 & 1,873 & 3,115 & 4,322 & 5,739 & 10,111 \\
\hline 171 & 07300000 & Salt Fork Red River near Wellington, Tex. & 5,551 & 14,635 & 23,694 & 39,403 & 54,724 & 72,810 & 127,423 \\
\hline 172 & 07300150 & Bear Creek near Vinson, Okla. & 338 & 881 & 1,429 & 2,384 & 3,312 & 4,404 & 7,783 \\
\hline 173 & 07300500 & Salt Fork Red River at Mangum, Okla. & 9,016 & 22,029 & 34,311 & 54,883 & 74,432 & 97,045 & 163,255 \\
\hline 174 & 07301110 & Salt Fork Red River near Elmer, Okla. & 9,979 & 24,454 & 38,131 & 61,059 & 82,865 & 108,110 & 182,003 \\
\hline 175 & 07301455 & Turkey Creek near Erick, Okla. & 625 & 1,564 & 2,480 & 4,041 & 5,531 & 7,266 & 12,509 \\
\hline 176 & 07301480 & Short Creek near Sayre, Okla. & 410 & 1,041 & 1,666 & 2,742 & 3,775 & 4,984 & 8,680 \\
\hline 177 & 07301500 & North Fork Red River near Carter, Okla. & 11,230 & 27,313 & 42,416 & 67,642 & 91,572 & 119,221 & 199,843 \\
\hline 178 & 07303400 & $\begin{array}{l}\text { Elm Fork of North Fork Red River near Carl, } \\
\text { Okla. }\end{array}$ & 3,749 & 9,619 & 15,386 & 25,282 & 34,847 & 46,054 & 79,737 \\
\hline 179 & 07303450 & Deer Creek near Plainview, Okla. & 826 & 2,101 & 3,361 & 5,528 & 7,617 & 10,059 & 17,499 \\
\hline 180 & 07303500 & $\begin{array}{l}\text { Elm Fork of North Fork Red River near Mangum, } \\
\text { Okla. }\end{array}$ & 6,781 & 16,535 & 25,747 & 41,176 & 55,820 & 72,752 & 122,425 \\
\hline 181 & 07309480 & Canyon Creek near Medicine Park, Okla. & 388 & 897 & 1,373 & 2,162 & 2,900 & 3,739 & 6,246 \\
\hline 182 & 07311000 & East Cache Creek near Walters, Okla. & 8,885 & 19,103 & 27,922 & 41,882 & 54,535 & 68,710 & 108,311 \\
\hline 183 & 07311200 & Blue Beaver Creek near Cache, Okla. & 1,183 & 2,741 & 4,188 & 6,577 & 8,811 & 11,358 & 18,871 \\
\hline 184 & 07311420 & Deadman Creek Trib. at Manitou, Okla. & 267 & 639 & 995 & 1,594 & 2,160 & 2,810 & 4,776 \\
\hline 185 & 07311500 & Deep Red Creek near Randlett, Okla. & 7,352 & 16,470 & 24,580 & 37,657 & 49,683 & 63,294 & 101,960 \\
\hline 186 & 07312850 & Nine Mile Beaver Creek near Elgin, Okla. & 577 & 1,309 & 1,984 & 3,091 & 4,118 & 5,282 & 8,720 \\
\hline 187 & 07312950 & Little Beaver Creek near Marlow, Okla. & 1,749 & 3,827 & 5,675 & 8,646 & 11,368 & 14,424 & 23,224 \\
\hline 188 & 07313000 & Little Beaver Creek near Duncan, Okla. & 3,866 & 8,428 & 12,438 & 18,848 & 24,696 & 31,264 & 49,921 \\
\hline 189 & 07313500 & Beaver Creek near Waurika, Okla. & 6,875 & 15,006 & 22,097 & 33,381 & 43,627 & 55,160 & 87,528 \\
\hline 190 & 07313600 & Cow Creek near Waurika, Okla. & 3,536 & 7,738 & 11,427 & 17,312 & 22,653 & 28,670 & 45,680 \\
\hline 192 & 07315680 & Cottonwood Creek Trib. near Loco, Okla. & 350 & 750 & 1,107 & 1,681 & 2,203 & 2,786 & 4,489 \\
\hline
\end{tabular}


Appendix 2. Peak-flow frequency statistics estimated by using basin characteristics from Tortorelli (1997) and StreamStats. The peak-flow statistics computed by using Tortorelli (1997) basin characteristics will not match those reported in Tortorelli (1997). The peak-flows reported in Tortorelli (1997) were computed from gaged data.-Continued

[Ark., Arkansas; Kans., Kansas; Mo., Missouri; N. Mex., New Mexico; Okla., Oklahoma; Tex., Texas; Trib., Tributary; S.H., State Highway; SWS, Subwatershed]

\begin{tabular}{|c|c|c|c|c|c|c|c|c|c|}
\hline \multirow{3}{*}{$\begin{array}{c}\text { Site } \\
\text { no. } \\
\text { (Tor- } \\
\text { tor- } \\
\text { elli, } \\
\text { 1997) }\end{array}$} & \multirow{3}{*}{$\begin{array}{l}\text { Station } \\
\text { no. }\end{array}$} & \multirow{3}{*}{ Station name } & \multicolumn{7}{|c|}{ StreamStats } \\
\hline & & & \multicolumn{7}{|c|}{$\begin{array}{l}\text { Estimated rural, unregulated peak-flow statistic (PKx), in cubic } \\
\text { feet per second, for recurrence interval in years }(x)\end{array}$} \\
\hline & & & PK2 & PK5 & PK10 & PK25 & PK50 & PK100 & PK500 \\
\hline 160 & 07247500 & Fourche Maline near Red Oak, Okla. & 7,102 & 13,158 & 17,913 & 25,045 & 31,248 & 37,922 & 55,905 \\
\hline 161 & 07249000 & Poteau River at Poteau, Okla. & 22,477 & 41,017 & 55,130 & 75,978 & 93,866 & 113,142 & 163,481 \\
\hline 162 & 07249300 & James Fork near Midland, Ark. & 4,281 & 8,222 & 11,428 & 16,335 & 20,684 & 25,389 & 38,399 \\
\hline 163 & 07249400 & James Fork near Hackett, Ark. & 7,529 & 14,219 & 19,540 & 27,582 & 34,622 & 42,232 & 62,853 \\
\hline 164 & 07249500 & Cove Creek near Lee Creek, Ark. & 4,155 & 7,622 & 10,352 & 14,453 & 18,025 & 21,849 & 32,257 \\
\hline 165 & 07249650 & Mountain Fork near Evansville, Ark. & 2,084 & 3,913 & 5,395 & 7,656 & 9,655 & 11,800 & 17,780 \\
\hline 166 & 07250000 & Lee Creek near Van Buren, Ark. & 13,216 & 25,515 & 35,389 & 50,415 & 63,676 & 78,090 & 117,149 \\
\hline 169 & 07299670 & Groesbeck Creek at S.H. 6 near Quannah, Tex. & 2,952 & 7,332 & 11,531 & 18,612 & 25,332 & 33,154 & 56,286 \\
\hline 170 & 07299705 & Bitter Creek near Hollis, Okla. & 442 & 1,144 & 1,848 & 3,070 & 4,254 & 5,645 & 9,927 \\
\hline 171 & 07300000 & Salt Fork Red River near Wellington, Tex. & 5,305 & 14,001 & 22,676 & 37,723 & 52,392 & 69,715 & 122,027 \\
\hline 172 & 07300150 & Bear Creek near Vinson, Okla. & 331 & 863 & 1,399 & 2,334 & 3,241 & 4,308 & 7,611 \\
\hline 173 & 07300500 & Salt Fork Red River at Mangum, Okla. & 8,471 & 20,733 & 32,315 & 51,719 & 70,145 & 91,476 & 153,924 \\
\hline 174 & 07301110 & Salt Fork Red River near Elmer, Okla. & 10,116 & 24,714 & 38,460 & 61,447 & 83,244 & 108,472 & 182,076 \\
\hline 175 & 07301455 & Turkey Creek near Erick, Okla. & 666 & 1,663 & 2,635 & 4,290 & 5,868 & 7,705 & 13,252 \\
\hline 176 & 07301480 & Short Creek near Sayre, Okla. & 418 & 1,060 & 1,696 & 2,789 & 3,840 & 5,067 & 8,821 \\
\hline 177 & 07301500 & North Fork Red River near Carter, Okla. & 11,293 & 27,324 & 42,308 & 67,252 & 90,832 & 118,054 & 197,129 \\
\hline 178 & 07303400 & $\begin{array}{l}\text { Elm Fork of North Fork Red River near Carl, } \\
\text { Okla. }\end{array}$ & 3,690 & 9,472 & 15,148 & 24,883 & 34,281 & 45,297 & 78,363 \\
\hline 179 & 07303450 & Deer Creek near Plainview, Okla. & 773 & 1,959 & 3,126 & 5,126 & 7,049 & 9,294 & 16,113 \\
\hline 180 & 07303500 & $\begin{array}{l}\text { Elm Fork of North Fork Red River near Man- } \\
\text { gum, Okla. }\end{array}$ & 6,397 & 15,622 & 24,337 & 38,928 & 52,759 & 68,765 & 115,678 \\
\hline 181 & 07309480 & Canyon Creek near Medicine Park, Okla. & 394 & 907 & 1,386 & 2,177 & 2,917 & 3,757 & 6,263 \\
\hline 182 & 07311000 & East Cache Creek near Walters, Okla. & 8,779 & 18,730 & 27,262 & 40,710 & 52,842 & 66,417 & 104,167 \\
\hline 183 & 07311200 & Blue Beaver Creek near Cache, Okla. & 1,164 & 2,706 & 4,140 & 6,510 & 8,728 & 11,258 & 18,729 \\
\hline 184 & 07311420 & Deadman Creek Trib. at Manitou, Okla. & 254 & 603 & 936 & 1,493 & 2,016 & 2,617 & 4,425 \\
\hline 185 & 07311500 & Deep Red Creek near Randlett, Okla. & 6,893 & 15,342 & 22,815 & 34,815 & 45,797 & 58,216 & 93,342 \\
\hline 186 & 07312850 & Nine Mile Beaver Creek near Elgin, Okla. & 579 & 1,312 & 1,986 & 3,090 & 4,114 & 5,274 & 8,696 \\
\hline 187 & 07312950 & Little Beaver Creek near Marlow, Okla. & 1,747 & 3,804 & 5,626 & 8,551 & 11,223 & 14,221 & 22,836 \\
\hline 188 & 07313000 & Little Beaver Creek near Duncan, Okla. & 3,720 & 8,056 & 11,846 & 17,881 & 23,363 & 29,514 & 46,917 \\
\hline 189 & 07313500 & Beaver Creek near Waurika, Okla. & 6,543 & 14,312 & 21,094 & 31,889 & 41,683 & 52,720 & 83,684 \\
\hline 190 & 07313600 & Cow Creek near Waurika, Okla. & 3,498 & 7,759 & 11,540 & 17,613 & 23,159 & 29,425 & 47,250 \\
\hline 192 & 07315680 & Cottonwood Creek Trib. near Loco, Okla. & 361 & 777 & 1,149 & 1,747 & 2,294 & 2,904 & 4,690 \\
\hline
\end{tabular}


Appendix 2. Peak-flow frequency statistics estimated by using basin characteristics from Tortorelli (1997) and StreamStats. The peakflow statistics computed by using Tortorelli (1997) basin characteristics will not match those reported in Tortorelli (1997). The peakflows reported in Tortorelli (1997) were computed from gaged data.-Continued

[Ark., Arkansas; Kans., Kansas; Mo., Missouri; N. Mex., New Mexico; Okla., Oklahoma; Tex., Texas; Trib., Tributary; S.H., State Highway; SWS, Subwatershed]

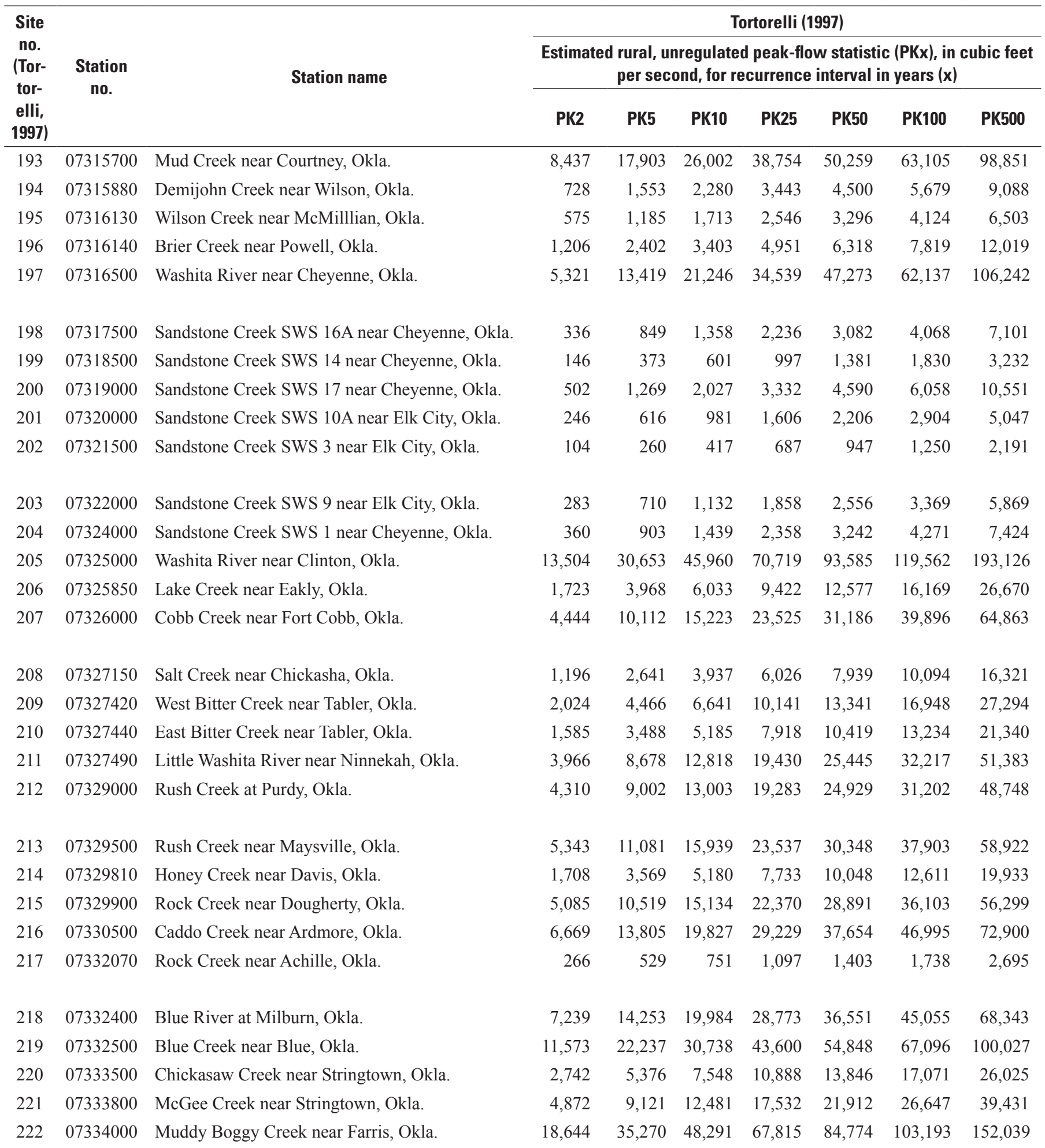


Appendix 2. Peak-flow frequency statistics estimated by using basin characteristics from Tortorelli (1997) and StreamStats. The peak-flow statistics computed by using Tortorelli (1997) basin characteristics will not match those reported in Tortorelli (1997). The peak-flows reported in Tortorelli (1997) were computed from gaged data.-Continued

[Ark., Arkansas; Kans., Kansas; Mo., Missouri; N. Mex., New Mexico; Okla., Oklahoma; Tex., Texas; Trib., Tributary; S.H., State Highway; SWS, Subwatershed]

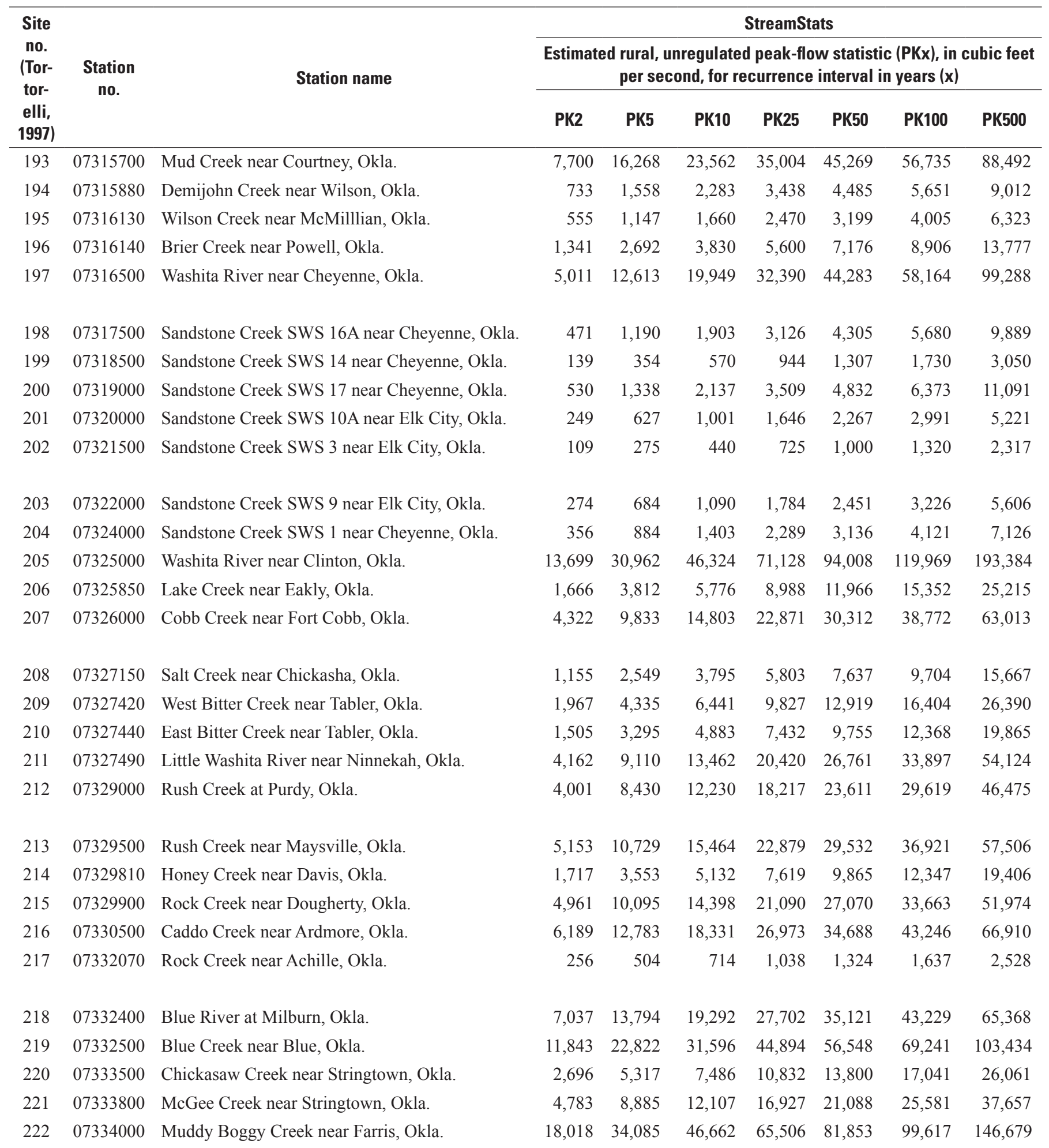


Appendix 2. Peak-flow frequency statistics estimated by using basin characteristics from Tortorelli (1997) and StreamStats. The peak-flow statistics computed by using Tortorelli (1997) basin characteristics will not match those reported in Tortorelli (1997). The peak-flows reported in Tortorelli (1997) were computed from gaged data.-Continued

[Ark., Arkansas; Kans., Kansas; Mo., Missouri; N. Mex., New Mexico; Okla., Oklahoma; Tex., Texas; Trib., Tributary; S.H., State Highway; SWS, Subwatershed]

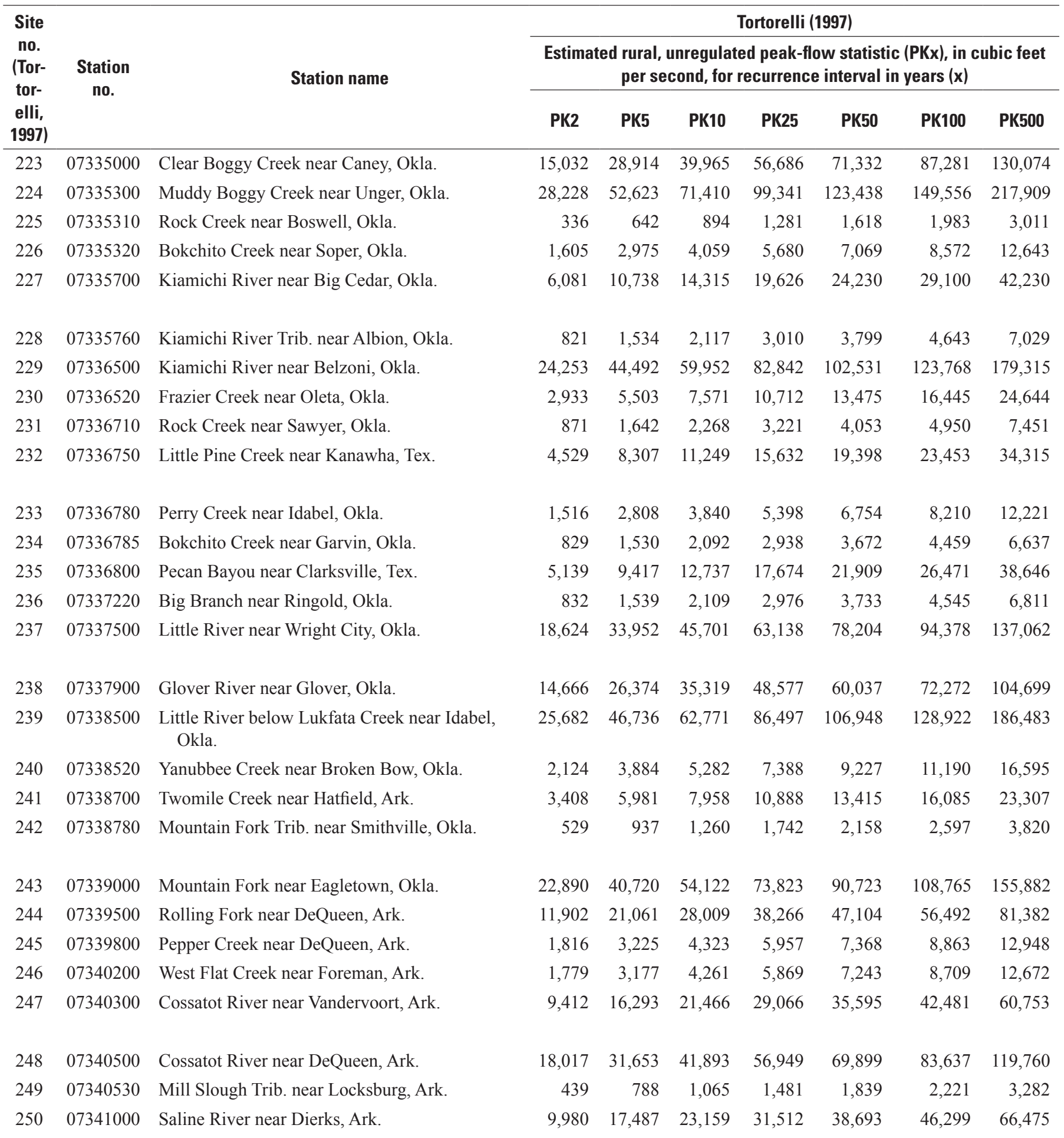


Appendix 2. Peak-flow frequency statistics estimated by using basin characteristics from Tortorelli (1997) and StreamStats. The peak-flow statistics computed by using Tortorelli (1997) basin characteristics will not match those reported in Tortorelli (1997). The peak-flows reported in Tortorelli (1997) were computed from gaged data.-Continued

[Ark., Arkansas; Kans., Kansas; Mo., Missouri; N. Mex., New Mexico; Okla., Oklahoma; Tex., Texas; Trib., Tributary; S.H., State Highway; SWS, Subwatershed]

\begin{tabular}{|c|c|c|c|c|c|c|c|c|c|}
\hline \multirow{3}{*}{$\begin{array}{c}\text { Site } \\
\text { no. } \\
\text { (Tor- } \\
\text { tor- } \\
\text { elli, } \\
\text { 1997) }\end{array}$} & \multirow{3}{*}{$\begin{array}{l}\text { Station } \\
\text { no. }\end{array}$} & \multirow{3}{*}{ Station name } & \multicolumn{7}{|c|}{ StreamStats } \\
\hline & & & \multicolumn{7}{|c|}{$\begin{array}{l}\text { Estimated rural, unregulated peak-flow statistic (PKx), in cubic feet } \\
\text { per second, for recurrence interval in years }(x)\end{array}$} \\
\hline & & & PK2 & PK5 & PK10 & PK25 & PK50 & PK100 & PK500 \\
\hline 223 & 07335000 & Clear Boggy Creek near Caney, Okla. & 13,370 & 25,569 & 35,219 & 49,750 & 62,390 & 76,161 & 112,899 \\
\hline 224 & 07335300 & Muddy Boggy Creek near Unger, Okla. & 28,599 & 53,251 & 72,223 & 100,422 & 124,751 & 151,110 & 220,086 \\
\hline 225 & 07335310 & Rock Creek near Boswell, Okla. & 371 & 714 & 999 & 1,436 & 1,820 & 2,237 & 3,414 \\
\hline 226 & 07335320 & Bokchito Creek near Soper, Okla. & 2,025 & 3,815 & 5,253 & 7,428 & 9,322 & 11,370 & 16,987 \\
\hline 227 & 07335700 & Kiamichi River near Big Cedar, Okla. & 6,547 & 11,315 & 14,922 & 20,237 & 24,818 & 29,636 & 42,538 \\
\hline 228 & 07335760 & Kiamichi River Trib. near Albion, Okla. & 938 & 1,744 & 2,401 & 3,405 & 4,295 & 5,244 & 7,927 \\
\hline 229 & 07336500 & Kiamichi River near Belzoni, Okla. & 24,995 & 45,707 & 61,498 & 84,858 & 104,950 & 126,597 & 183,186 \\
\hline 230 & 07336520 & Frazier Creek near Oleta, Okla. & 2,531 & 4,683 & 6,393 & 8,968 & 11,207 & 13,613 & 20,193 \\
\hline 231 & 07336710 & Rock Creek near Sawyer, Okla. & 887 & 1,657 & 2,280 & 3,224 & 4,046 & 4,931 & 7,389 \\
\hline 232 & 07336750 & Little Pine Creek near Kanawha, Tex. & 4,614 & 8,384 & 11,298 & 15,622 & 19,323 & 23,301 & 33,915 \\
\hline 233 & 07336780 & Perry Creek near Idabel, Okla. & 1,478 & 2,711 & 3,689 & 5,158 & 6,429 & 7,793 & 11,531 \\
\hline 234 & 07336785 & Bokchito Creek near Garvin, Okla. & 815 & 1,494 & 2,035 & 2,848 & 3,549 & 4,302 & 6,378 \\
\hline 235 & 07336800 & Pecan Bayou near Clarksville, Tex. & 5,017 & 9,200 & 12,448 & 17,277 & 21,418 & 25,881 & 37,789 \\
\hline 236 & 07337220 & Big Branch near Ringold, Okla. & 837 & 1,534 & 2,092 & 2,937 & 3,672 & 4,458 & 6,646 \\
\hline 237 & 07337500 & Little River near Wright City, Okla. & 21,030 & 37,829 & 50,594 & 69,469 & 85,757 & 103,168 & 148,984 \\
\hline 238 & 07337900 & Glover River near Glover, Okla. & 15,008 & 26,838 & 35,838 & 49,147 & 60,629 & 72,871 & 105,246 \\
\hline 239 & 07338500 & $\begin{array}{l}\text { Little River below Lukfata Creek near Idabel, } \\
\text { Okla. }\end{array}$ & 27,354 & 49,342 & 65,985 & 90,544 & 111,682 & 134,336 & 193,535 \\
\hline 240 & 07338520 & Yanubbee Creek near Broken Bow, Okla. & 2,023 & 3,654 & 4,937 & 6,858 & 8,522 & 10,296 & 15,151 \\
\hline 241 & 07338700 & Twomile Creek near Hatfield, Ark. & 3,288 & 5,792 & 7,720 & 10,581 & 13,047 & 15,658 & 22,721 \\
\hline 242 & 07338780 & Mountain Fork Trib. near Smithville, Okla. & 498 & 877 & 1,175 & 1,620 & 2,001 & 2,405 & 3,523 \\
\hline 243 & 07339000 & Mountain Fork near Eagletown, Okla. & 23,779 & 42,096 & 55,817 & 75,953 & 93,210 & 111,608 & 159,581 \\
\hline 244 & 07339500 & Rolling Fork near DeQueen, Ark. & 11,936 & 21,067 & 27,979 & 38,172 & 46,944 & 56,258 & 80,920 \\
\hline 245 & 07339800 & Pepper Creek near DeQueen, Ark. & 1,757 & 3,114 & 4,168 & 5,737 & 7,088 & 8,520 & 12,426 \\
\hline 246 & 07340200 & West Flat Creek near Foreman, Ark. & 1,775 & 3,155 & 4,221 & 5,797 & 7,141 & 8,575 & 12,440 \\
\hline 247 & 07340300 & Cossatot River near Vandervoort, Ark. & 9,730 & 16,671 & 21,848 & 29,427 & 35,919 & 42,747 & 60,806 \\
\hline 248 & 07340500 & Cossatot River near DeQueen, Ark. & 18,183 & 31,890 & 42,171 & 57,278 & 70,265 & 84,037 & 120,227 \\
\hline 249 & 07340530 & Mill Slough Trib. near Locksburg, Ark. & 465 & 828 & 1,116 & 1,547 & 1,918 & 2,311 & 3,404 \\
\hline 250 & 07341000 & Saline River near Dierks, Ark. & 10,239 & 17,798 & 23,476 & 31,816 & 38,969 & 46,530 & 66,533 \\
\hline
\end{tabular}


Appendix 2. Peak-flow frequency statistics estimated by using basin characteristics from Tortorelli (1997) and StreamStats. The peak-flow statistics computed by using Tortorelli (1997) basin characteristics will not match those reported in Tortorelli (1997). The peak-flows reported in Tortorelli (1997) were computed from gaged data._Continued

[Ark., Arkansas; Kans., Kansas; Mo., Missouri; N. Mex., New Mexico; Okla., Oklahoma; Tex., Texas; Trib., Tributary; S.H., State Highway; SWS, Subwatershed]

\begin{tabular}{|c|c|c|c|c|c|c|c|}
\hline $\begin{array}{c}\text { Summary of comparison of statistics } \\
\text { computed by Tortorelli (1997) and } \\
\text { StreamStats }\end{array}$ & PK2 & PK5 & PK10 & PK25 & PK50 & PK100 & PK500 \\
\hline $\begin{array}{l}\text { using Tortorelli (1997) } \\
\text { basin characteristics }\end{array}$ & 124 & 131 & 133 & 136 & 138 & 139 & 140 \\
\hline $\begin{array}{l}\text { using StreamStats } \\
\text { basin characteristics }\end{array}$ & 84 & 77 & 75 & 72 & 70 & 69 & 68 \\
\hline \multicolumn{8}{|l|}{ Average relative percent difference: } \\
\hline $\begin{array}{l}\text { of statistics that are } \\
\text { greater in Tortorelli } \\
\text { (1997) }\end{array}$ & 5.32 & 5.23 & 5.30 & 5.35 & 5.41 & 5.48 & 5.67 \\
\hline
\end{tabular}


